\title{
INTERNATIONAL ENERGY AGENCY
}

\section{(IEA) WORKING PARTY ON ENERGY CONSERVATION \\ RESEARCH AND DEVELOPMENT}

\section{ANNUAL REPOR
1976-1977}

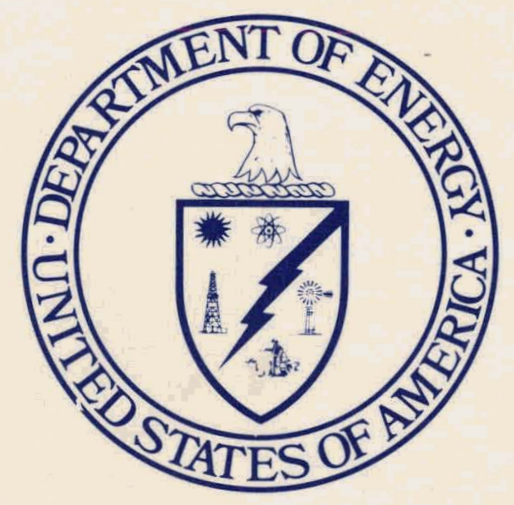

\section{NOTICE}

THIS REPORT IS ILLEGIBLE TO A A DEGRET 7 ? THAT PRECLUDES SAIISEACTORY REPRODUCIION

\section{August 1977}

United States Department of Energy

Division of Building and Community Systems 


\section{DISCLAIMER}

This report was prepared as an account of work sponsored by an agency of the United States Government. Neither the United States Government nor any agency Thereof, nor any of their employees, makes any warranty, express or implied, or assumes any legal liability or responsibility for the accuracy, completeness, or usefulness of any information, apparatus, product, or process disclosed, or represents that its use would not infringe privately owned rights. Reference herein to any specific commercial product, process, or service by trade name, trademark, manufacturer, or otherwise does not necessarily constitute or imply its endorsement, recommendation, or favoring by the United States Government or any agency thereof. The views and opinions of authors expressed herein do not necessarily state or reflect those of the United States Government or any agency thereof. 


\section{DISCLAIMER}

Portions of this document may be illegible in electronic image products. Images are produced from the best available original document. 
This report was prepared as an account of work sponsored by the United States Government. Neither the United States nor the United States Department of Energy, nor any of their employees, nor any of their contractors, subcontractors, or their employees, makes any warranty, express or implied, or assumes any legal liability or responsibility for the accuracy, completeness or usefulness of any information, apparatus, product or process disclosed, or represents that its use would not infringe privately owned rights.

Available from:

National Technical Information Service (NTIS)

U.S. Department of Commerce

5285 Port Royal Road

Springfield, Virginia 22161

Price: Printed copy:

Microfiche:

$\$ 3.00$ 


\section{INTERNATIONAL ENERGY AGENCY (IEA) WORKING PARTY ON ENERGY CONSERVATION RESEARCH AND DEVELOPMENT ANNUAL REPORT \\ 1976-1977}

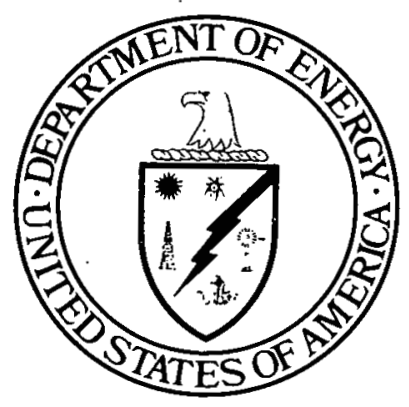

NOMZOE

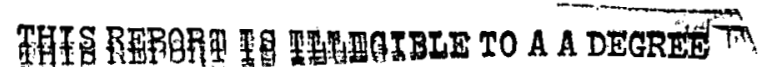

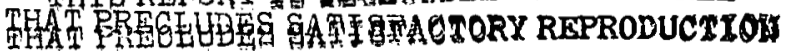

\section{August 1977}

\section{United States Department of Energy}

Division of Building and Community Systems

Washington, D.C. 20545

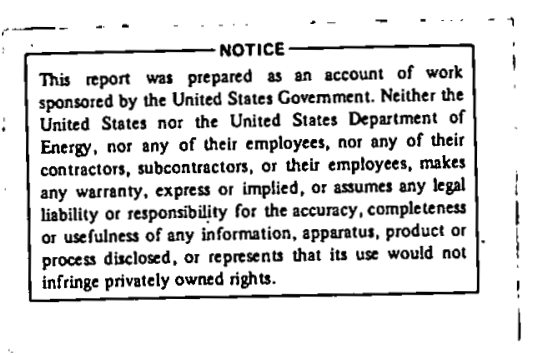


INTRODUCTION

BUILDINGS AND COMMUNITY SYSTEMS

COMBUSTION

CONSERVATION IN BUILDING COMPLEXES

ENERGY CASCADING

EKISTICS

11

ENERGY STORAGE

HEAT PUMPS

HEAT TRANSFER

APPENDIX A: MEMBERSHIP OF THE WORKING PARTY ON ENERGY CONSERVATION R\&D

$\mathrm{A}-1$

APPENDIX B: IMPLEMENTING AGREEMENTS

$\mathrm{B}-1$ 
The oil embargo of 1973 and the consequent sharp rise in world oil prices severely disrupted the economies and strained the political, strategic, and economic relationships of most oil-importing nations. Inadequate cooperation among the industrialized nations resulted in competitive unilateral efforts by many to ensure current and future supplies of oil.

In recognition of the need to unite in a coordinated effort to decrease dependence on foreign oil and thereby reduce strategic and economic vulnerability, the United States and most other members of the organization for Economic Cooperation and Development (OECD) agreed in September 1974 to develop an International Energy Program (IEP). The program was to serve as a vehicle for the participating nations to cooperate on energy research and development ( $R \& D$ ) programs and to share energy imports in times of emergency. To administer, monitor, and execute the IEP, the participating nations established the International Energy Agency (IEA) as an autonomous institution within OECD. Nineteen nations are currently participating in IEA: Austria, Belgium, Canada, Denmark, the Federal Republic of Germany, Greece, Ireland, Italy, Japan, Luxembourg, the Netherlands, New Zealand, Norway, Spain, Sweden, Switzerland, Turkey, the United Kingdom, and the United States. Under special arrangement (Article 72 of the basic agreement), the European Community and OECD's Nuclear Energy Agency also participate.

At IEA's initial meeting in November 1974, the following specific objectives were defined:

- Promote secure oil supplies

- Develop an emergency self-sufficiency in oil supplies, restrain demand, and allocate available oil among member countries on an equitable basis

- Promote cooperative relations with oil-producing countries and other oil-consuming countries, including those of the developing world

- Reduce member-country dependence on imported oil by undertaking long-term cooperative efforts on energy conservation, accelerated development of alternative sources of energy, energy research and development, and uranium supply and enrichment.

To accomplish these objectives, four standing groups were established:

- Emergency questions

- Oil market 
- Long-term cooperation

- Relations with producer and other consumer countries.

Under the Standing Group on Long-Term Cooperation, four major areas were designated, including energy $R \& D$. In recognition of the broad scope of this area, in November 1975, energy R\&D was redesignated a committee with equal status to the four standing groups.

As IEA members express interest in developing and conducting cooperative energy $\mathrm{R} \& \mathrm{D}$ projects, working parties comprising representatives of the member nations interested in participating in a particular project are established. Under the chairmanship of a designated lead country or organization, each working party seeks to develop a cooperative program of mutually beneficial projects relating to various energy technologies.

To date, the Committee on Energy R\&D has established 15 working parties to conduct cooperative energy $R \& D$ projects:

- Biomass Conversion

- Coal Technology

- Conservation R\&D

- Energy R\&D Strategy

- Fusion

- Geothermal

- High-Temperature Reactors for Process Heat

- Hydrogen

- Nuclear Safety

- Ocean Thermal Energy Conversion

- Radioactive Waste Management

- Small Solar Power Systems

- Solar Energy

- Wave Power

- Wind Power. 
The Working Party on Conservation R\&D was established to promote cooperative implementation of energy conservation R\&D programs. The working party has defined four objectives that guide its research activities:

- Develop an international mechanism by which energy conservation research, development, and demonstration can be performed for the maximum mutual benefit of participants, and accelerate the realization of these benefits

- Identify areas of mutual interest which represent major opportunities for more efficient utilization of energy

- Define and actuate mechanisms by which information and/or research results will be developed and exchanged

- Undertake cooperative research, development, and demonstration projects in areas that have major energy conservation potential and that maximize the coordination of national R\&D programs.

The United States, represented by Dr. Melvin H. Chiogioji of the United States Energy Research and Development Administration (ERDA), is leading the efforts of the Working Party on Conservation. The other participating nations and organizations are Austria, Belgium, Canada, Denmark, the Federal Republic of Germany, Greece, Ireland, Italy, Japan, the Netherlands, New Zealand, Norway, Spain, Sweden, Switzerland, the United Kingdom, and the European Community.

Participating countries sign implementing agreements and annexes to formalize the terms of their participation in a specific project area. The implementing agreement formalizes the commitment of two or more countries to cooperate in R\&D efforts; each annex formalizes commitment to a specific research activity. When signing an implementing agreement, interested parties must also sign at least one annex.

Under the provisions of an implementing agreement, an executive committee has overall responsibility for developing and implementing work in the project area. An operating agent to coordinate the specific activities under each annex is designated in the agreement.

Presently, the Working Party on Conservation R\&D has implementing agreements and is performing work in seven areas: buildings and community systems; building complexes; ekistics; combustion; energy cascading; heat pumps; and heat transfer. New agreements are likely in the area of industrial processes, materials, and energy storage. A number of subgroups, called expert groups, have been formed to conduct specific cooperative projects within these areas.

The following annual report of the IEA Working Party on Energy Conservation briefly describes the background and objectives of each project area, the status of its implementing agreement, its organizational structure, and current activities. Appendix $A$ lists the members of the Working Party on Energy Conservation R\&D. Copies of the implementing agreements that have been signed to date (on energy cascading, combustion, heat pumps, buildings and community systems, building complexes, and ekistics) are included as Appendix B. 
In response to a high level of interest, the United States proposed this project to examine the possibilities for energy conservation through improved design of buildings and community systems. A major, long-term effort will be undertaken to provide the participating nations with an international 'ramework for independently evaluating, predicting, and comparing load and energy usage for different materials, building designs, and equipment. Within this framework, the participating countries will be able to use an internationally accepted series of analytical techniques to develop codes, standards, and labeling to encourage international commerce in the area of energy conservation for buildings.

The buildings and community systems project is the first cooperative R\&D project with broad participation from the private sector. Currently, 13 industrial organizations and 6 universities are contributing to the cooperative work, either as direct contracting parties or through their governments.

\section{STATUS OF THE IMPLEMENTING AGREEMENT}

The implementing agreement and an annex on thermal characteristics of buildings were signed in March 1977. Under the annex, work will be conducted on modeling infiltration in naturally ventilated buildings and on comparing the performance of an instrumented building and a real building. In addition, the operating agent has proposed that the executive committee adopt the ekistics project as an annex.

\section{ORGANIZATION}

The executive committee is composed of 15 contracting parties from Canada, Italy, Sweden, Switzerland, the United Kingdom*, and the United States. The chairman of the executive committee is Mr. Gerald S. Leighton of the United States; the vice chairman is Mr. David Curtis of the United Kingdom. The United States, through the Energy Research and Development. Administration (ERDA), serves as operating agent.

In addition to the : articipants represented on the executive committee, Austria, Denmark, and Germany have indicated strong interest in the implementing agreement.

\section{CURRENT AND PROPOSED ACTIVTTIES .}

Analysts from Canada, Sweden, the United Kingdom, and the United States analyzed an office building with sealed windows (previously defined as standard) and reviewed the results. Through November 1977, researchers will analyze the building again, using more detailed specifications and

* Ten industrial and university contracting parties from the United Kingdom are participating. 
weather data to determine the extent to which differences among individual programs account for variations in findings. The operating agent will develop a research agenda to improve the modeling of infiltration in both sealed: and naturally ventilated buildings. Finally, the United Kingdom will develop a research program based on an instrumented building to compare analyeic resulis with real building performance. 


\section{COMBUSTION}

In.1976, energy conservation in combustion was established as a separate project area with the objective of improving the energyefficiency of combustion technologies and developing the fuel-switching capability of combustion equipment. Cooperative research and development efforts and information exchange among participating parties are currently under way.

\section{STATUS OF THE IMPLEMENTING AGREEMENT}

In March 1977, an implementing agreement and an annex entitled Energy Conservation in Combustion were signed. The contracting parties will investigate methods for improving the information, instrumentation, and calculating procedures used in the design, manufacture, and operation of combustion equipment.

\section{ORGANIZA'TION}

Dr. Karl Bastress of the U.S. Energy Research and Development Administration (USERDA) is serving as chairman of the executive committee. Other members include the National Swedish Board for Energy Source Development (SWNE), designated by Sweden; the U.K. Atomic Energy Authority (UKAEA), designated by the United Kingdom; and USERDA. In addition, preliminary discussions have been held with the Federal Republic of Germany (FRG); a representative of the FRG will be invited to the August 1977 meeting of the executive committee in Sweden.

USERDA has been designated operating agent for the agreement.

\section{CURRENT AND PROPOSED ACTIVITIES}

Within the agreement, three specific areas for investigation have been identified: (1) combustion system modeling; (2) instrumentation and studies of fundamental processes in combustion; (3) and resource exchange. In accordance with the provisions of the implementing agreement, USERDA and UKAEA have accepted responsibility for the first task, all members of the executive committee are undertaking aspects of task 2, and USERDA and UKAEA will assume responsibility for task 3.

Research in combustion-system modeling is directed toward developing combustion technology for engines and furnaces. In the work related to fundamental processes in combustion, participants will develop instruments and experimental techniques for measuring fundamental 
parameters and properties of combustion systems, and investigate the basic physical phenomena relevant to the combustion process. The purpose of the third area, resource exchange, is to provide for information exchange among the contracting parties on such subjects as the objectives and results of past programs, numerical analysis methods, laboratory analysis, and experimental test facilities. 
Two programs are being conducted under this project, in Esslingen and wiehl, both in the Federal Republic of Germany. The program of work associated with the design and implementation of the experimental activities at the two facilities involves the exchange of technical personnel; sharing of information; design, execution, and evaluation of agreed-upon experiments; and joint funding.

Under the Esslingen program, all space heating and domestic hot-water requirements for a complex of three high-rise apartment buildings is provided through a central water-to-water heat pump system which extracts heat from river water. The building complex also has an alternate oilfired heating system which can meet the fuil heating requirements. The performance of the heat-pump system will be compared with that of oilfired heating over a period of 3-5 years.

The Wiehl program involves a large-scale experimental plant consisting of a. multipurpose community recreational facility whose energy system features integrated subsystems (e.g., waste-heat utilization, heat recovery from wastewater and ventilation exhaust, wastewater utilization, heat-loss reduction, solar-energy collection, and heat pumps). Tests, analyses, and technological studies and evaluations will be conducted over a period of 5-10 years.

STATUS OF. THE IMPLEMENTING AGREEMENT

Currently, work in this project is being conducted under a bilateral agreement between the Federal Republic of Germany and the United States.

\section{ORGANIZATION}

The Federal Republic of Germany and the United States are the two participants in this project, with the Federal Republic of Germany acting as the operating agent. The Executive Committee consists of $\mathrm{Dr}$. Helmut Klein of Germany and Mr. Gerald Leighton of the United States.

\section{CURRENT AND PROPOSED ACTIVITIES}

Both the WiehI and Esslingen sites are in operation. By the end of 1977, participants expect to have completed initial test runs and to have installed automatic data-collection systems at both sites. In addition, the expanded evaluation program will be defined. 


\section{ENERGY CASCADING}

Enerqy cascading is the uoc of wasle energy, usually in the form of heat, for such applications as electricity generation, process heating, or space heating that would otherwise be served by primary energy sources. In the current energy-cascading project area, participants are attempting to provide an overall program plan for facilitating the technical and commercial success of research and development projects related to: (1) all-electric systems for high-efficiency electricity generation; (2) combined systems, which supply energy through electricity generation as well as through other forms of energy; (3) all-heat energy systems in which no electricity is produced; and (4) total systems, which maximize the efficiency of overall energy utilization from source to ultimate end-use. Within these groupings, specific areas of interest include the treble Rankine cycle process, the total integrated energy system, recovery of industrial flue gas heat with the Brayton cycle, and recovery of heat from diesel-powered engines with the Brayton cycle.

\section{STATUS OF IMPLEMENTING AGREEMENT}

The implementing agreement and an annex entitled Energy Cascading Common study were signed in March 1977.

\section{ORGANIZATION}

Dr.G. E. Rajakovics of Austria is the chairman of the executive committee of this project and Mr. Gerald S. Leighton of the United States is the vice chairman. Other members of the executive committee include the Kernforschungsanlage Julich G.m.b.H., designated by the Federal Republic of Germany; the National Swedish Board for Energy Resource Development, designated by Sweden; and the Office Fédéral de la Science et de la Récherche du Département Fédéral de L'Intérieur, for and on behalf of Switzerland. In addition, a number of other parties have expressed interest in this project area, namely, Belgium, the European Community, Italy, the Netherlands, and the United Kingdom.

The operating agent for the annex is the U.S. Energy Research and Development Administration.

\section{CURRENT AND PROPOSED ACTIVITIES}

Since October 1976, participating countries have negotiated agreements to govern the joint funding and management of the energy cascading common study. 
In April 1977, work on the common study formally began and participating countries agreed to collect required data in the four areas designated under energy cascading. The executive committee proposes to meet in August and later in mid-November 1977 to discuss the results of the datacollection efforts. 
To achieve maximum energy conservation on a community scale, the analytical methods and design tools traditionally used by the urban-design and energy-systems professions must be combined and then applied to communities. The participants in this project are seeking to develop a practical and widely applicable community-design methodology and ekistic-energy analytical matrix for use by urban designers and engineers.

\section{STATUS OF THE IMPLEMENTING AGREEMENT}

Greece and the United States have signed a bilateral agreement to begin work on this project. The ekistics project will be added as Annex II to the implementing agreement on buildings and community systems.

\section{ORGANIZATION}

Greece and the United States are participating in this project, with Greece acting as the operating agent.

\section{CURRENT AND PROPOSED ACTIVITIES}

Thus far, a scope of work, detailed work-management plan, and project methodology have been developed. The Greek government has selected subcontractors and work has been initiated to build a demonstration of the ekistic energy development of a specific site. At the conclusion of the project, a conference on ekistics and energy will be held to present the project results. 
ENERGY STORAGE

The objective of this project area is to demonstrate experimentally new techniques for large- and small-scale thermal storage, to validate mathematical models of heat transfer in a deep aquifer, and to investigate flywheel energy-storage applications in transportation. All projects will be developed with an exchange of funds, personncl, and information among participating countries.

\section{STATUS OF THE IMPLEMENTING AGREEMENT}

Drafts of an implementing agreement and four annexes are being prepared. The agreement is expected.to be signed by the end of 1977 .

\section{ORGANIZATION}

The Federal Republic of Germany is acting as the lead country in this project area. A number of other countries and organizations are participating as well, including Austria, Belgium, Denmark, the Netherlands, Sweden, Switzerland, and the United States. The European Community has expressed interest in the project area.

\section{CURRENT AND PROPOSED ACTIVITIES}

The proposed projects include long-term storage for district and simple-dwelling heating, and seasonal storage in acquifers. In the Federal Republic of Germany, researchers are experimenting with storage of waste heat in artificial lakes. In addition, a number of other activities have been proposed in this project area, including flywheels in subways, chemical heat-pump storage systems, and solar-heated houses. 
The objectives of this program are to conduct theoretical and experimental development programs on heat-pump systems and to provide a centrial collection, collation, and distribution center for the exchange of information on heat pumps with thcrmal-storage capabilities. The program will be limited to heat-pump systems with thermal storage for generating domestic space and water heating by use of the compression cycle.

\section{STATUS OF THE IMPLEMENTING AGREEMENT}

An implementing agreement, and an annex entitled Heat Pump systems with Thermal Storage were signed in March 1977.

\section{ORGANIZATION}

The executive committee for this project area is composed of participants from Austria, Denmark, the Federal Republic of Germany, Ireland, Italy, Sweden, Switzerland, and the United States. In addition, the Netherlands and the European Community have stated their intention to join the project area. The chairman of this committee is Mr. Jacobs of Denmark; Mr. Gerald Leighton of the United States is vice-chairman.

Austria is serving as the operating agent for the agreement.

\section{CURRENT AND PROPOSED ACTIVITIES}

Each contracting party has assumed responsibility for a project relating to demonstration of a heat-pump system with thermal storage. Specifically:

- Austria is demonstrating a model home that utilizes an air-towater heat pump for space and residential water heating. Outdoor aix provides the source of heat, which is transferred to and extracted from the storing subsoil by means of an aerated gravel bed.

- The European Community is considering the possibility of operating an electrically driven heat-pump system combined with heat storage.

- Denmark will evaluate the projects contributed by the other participating countries, and prepare and publish reports in cooperation with the operating agent. 
- Germany is conducting two projects: a demonstration of a model home using a heat-pump system with water/ice latent heat storage; and a project involving an earth-heating pump with switching capacity to external air.

- Ireland has developed an air-source heat pump system with shortterm water-storage units to meet possible space- and water-heating requirements of a typical domestic unit.

- Italy is demonstrating a heat-pump system operated by an independent power generator (diesel engine) and designing and constructing a prototype organic fluid turbine prime mover.

- The Netherlands will study the thermodynamics of different heatpump systems and experiment with process-cintrol instrumented heat pumps in inhabited residential houses.

- Sweden is involved in at least one project using a heat pump in connection with a thermal-storage system and demonstrating alternative heat sources for heat pumps in residential houses.

- Switzerland is developing a heat-pump application with warmwater storage using the ground as heat source for space heating by Berner Kraft-werke AG.

- The United States is demonstrating the capability of the Annual Cycle Energy System (ACES). The principal component of this system is an insulated tank of water that serves as a thermalstorage bin. 
The participants in the heat transfer project are seeking, through cooperative R\&D and information exchange, to improve the design and operation of heat-transfer systems, particularly heat exchangers, as a means of conserving fuel. The specific objectives of the project are to: (1) increase the efficiency of thermal-energy conservation through the development of more effective heat-transfer systems; (2) reduce free energy losses in processes by facilitating the operation of heat-exchange systems at reduced temperature differences without unacceptable capital-cost requirements; and (3) investigate mechanical and other design constraints to the achievement of higher thermal efficiencies.

\section{STATUS OF THE IMPLEMENTING AGREEMENT}

An implementing agreement and annexes to cover research in each of three project areas (i.e., extended-surface heat transfer, optimal design of heat-exchanger networks, and heat-exchanger tube vibration) were signed in June 1977.

\section{ORGANIZATION}

Currently, Sweden, Switzerland, the United Kingdom, and the United States are participating in this effort, with the United Kingdom acting as lead country. The experts group is chaired by Dr. G. F. Hewitt of the United Kingdom.

\section{CURRENT AND PROPOSED ACTIVITIES}

The executive committee recently decided to organize additional research in the three designated project areas. 


\section{INDUSTRIAL PROCESSES}

This project area was established in 1976 to develop cooperative R\&D projects in the area of industrial processes, particularly in the cement, chemicals, iron and steel, and pulp and paper industries. To ensure that the projects developed are directly relevant to industrial needs, extensive consultations with private industry are being undertaken in all sectors.

\section{STATUS OF THE IMPLEMENTING AGREEMENT}

Implementing agreements are being developed in the cement and iron and steel sectors.

\section{ORGANIZATION}

Mr. Steaffan Ulvonäs from the National Swedish Board for Technical Development is the chairman of the experts group.

\section{CURRENT AND PROPOSED ACTIVITIES}

To date, participants have made initial recommendations for cooperative research and development efforts according to industrial sector. For example, in the cement sector, four projects were defined:

1. Provide information on permissible expansion and shrinkage units for cements, and establish appropriate guidelines for maximum sulfate content

2. Document the use of blended cements wherever technically justified

3. Investigate means for releasing and collecting alkali so that it can be removed from the cement-manufacturing system in the most efficient manner

4. Investigate the parameters governing concrete quality with respect to alkali content and reactivity of aggregate.

In the chemicals industry, five proposed areas for further consideration were identified, including: the use of waste hydrogen and carbon monoxide as chemical feedstock in steelmaking plants; the use of gas turbines in 
chemical operations; the reduction of mercury emissions from chlorine plants; the development of a mechanism for transporting large volumes of low-grade heat; and the use of electrochemistry for organic and chemical synthesis.

To increase energy efficiency in the pulp and paper industry, working group members recommended research into defibration of wood, increased use of waste paper in the production of paper, and the use of flue gases in debarking wood. 
The materials project was established in July 1976 to: (1) identify specific areas of materials technology with substantial relevance to energy conservation; and (2) assess the need for research and development in these areas. According to the experts group, materials technology can contribute to both the IEA energy conservation R\&D program and to other aspects of the IEA energy research and development area, including wind and wave power and coal gasification.

\section{STATUS OF THE IMPLEMENTING AGREEMENT}

Members of the experts group have agreed to assess the need for further research and development in specified topics within the materials area. In May 1977, a decision will be made whether to form a new project area in one of these fields or add a materials task to an existing project.

\section{ORGANIZATION}

The United Kingdom has taken the lead in this area, with Dr. Derek E. Pooley acting as chairman of the experts group. The other participating nations include Canada, the Federal Republic of Germany, Italy, Japan, the Netherlands, Switzerland, the United Kingdom, and the United States.

\section{CURRENT AND PROPOSED PROJECTS}

The group anticipates that materials technology may significantly influence the long-term impact of four existing IEA conservation projects, namely, combustion, energy cascading, heat transfer, and energy storage. Accordingly, members of the experts group have requested the managers of these project areas to provide feedback on the perceived need for additional materials research in their areas.

The experts group also identified the following aspects of materials technology as having substantial relevance to energy conservation:

- Integrity of containment materials for heat transport and storage systems, with respect to corrosion embrittlement.

- Factors influencing the performance and long-term reliability of high-temperature materials that have potential application in engines and heat exchangers (e.g., nondestructive techniques for testing ceramics) 
- Materials aspects of Rankine cycle engines

- Materials factors influencing the use of lightweight

structural materials such as aluminium alloys and reinforced plastics in land vehicles.

All members of the group agreed to discuss these proposed topics within their own countries and assess the ongoing research and development in any of these areas. Currently, Dr. Pooley is collecting this information and will present it to the energy conservation working party in May. 
APPENDIX A

Membership of the Working Party on

Energy Conservation R\&D 
CHAI RMAN :

AUSTRIA

BELGIUM

CANADA
Dr. M. H. CHIOGIOJI

Assistant Director for

Systems Analysis

nffire of coneervation

ERDA

washington, D.C. 20545

Professor P. V. GILLI

Institut für Dampfkesselbau

Reaktortechnik und

wärmewirtschaft

Technische Universität Graz

Kopernikusgasse, 24

A-8010 . GRAZ

Dr. G. E. RAJAKOVICS

Vereinigte Edelstahlwerke

A. G.

(Ministry of. Science and

Research, Vienna)

Mayergasse, 11

A-1020 WIEN

Mr. J. C. DELCROIX

Directeur Opérationnel,

Services de Programmation de la Politique Scientifique

Rue de la Science 8

B-1040 BRUSSELS

Mr. D. QUINSEY

Department of Energy, Mines and

Resources

580 Booth street

OTTAWA, KIA CE4

ONTARIO 
Mr. N. O. GRAM

Ministry of Industry

Slotholmsgade 12

DK-1249 COPENHAGEN

Mr. B. QVALE

Laboratory for Energetics

Technical University of Denmark

Building 403

DK-2800 LYNGBY

GERMANY

Mr. J . MOHNFELD

German Delegation to OECD

5 rue Léonard-de-vinci

75116 .PARIS

Dr. U. PLANTIKOW

Projektleitung Energie-

Kernforschungsanlage. Juelich $\mathrm{GmbH}$

D-5170 JUELICH, I

Postfach 1913

IRELAND

Mr. J.G. DUGGAN

National Science Council

St. Martin's House

Waterloo Road

DUBLIN, 4

ITALY

Mr. G. FARELLO

Consiglio Nazionale delle Ricerche

Directorate for the rinalized

Energy Project

Via Morgagni. 30/E

ROMA

JAPAN

Mr. K. SHIMO

Japanese Delegation to OECD

7 avenue Hoce

75008 PARIS

NETHERLANDS

Mr. J.A. KNOBBOUT

Centre for the study of Energy

Problems (TNO)

Laan v. Westenenk, 501

P.O. 342

APELDOORN 
NORWAY

SPAIN

SWEDEN

SWITZERLAND

UNITED KINGDOM
Mr. J. A. MORTENSEN

Ministry of Industry

DEP. . OSLO

OSLO

Mr. J.A. GONZALEZ

Centro de Estudios de la

Energia

Ditustin de Foxa $29-1$

MADRID 16

Dr. M. GASCA

Enpetrol SA.

Embajadores, 183

MADRID, 5.

Dr: K.A. EDIN

Energy Research. and Development Commission

Syeavägen 13-15

S-111 57. STOCKHOLM

Dr. R. HOFFMAN

Office of Science and Research

Wildhainweg 9

Case Postale 2732

$\mathrm{CH}-3001$ BERNE

Dr. J. BUTTERWORTH

Energy Technology Support

Unit (ETSU)

AERE

Harwell, Didcot

OXON, OXII, ORA

Dr. G. F. HEWITT

Head of Thermodynamics Div.

AERE

Harwell, Didcot

OXON. OXII ORA 
Mr.G.S. LEIGHTON

Assistant Director

Division of Buildings and

Community systems

ERDA

WASHINGTON, D.C. 20545

Mr. M. PERLSWEIG

Chief, Thermodynamics and Heat Transfer Branch

ERDA

WASHINGTON, D.C. 20545

Mr. G.F. PEZDIRTZ

Director, Division of Fnergy

Storage systems

ERDA

WASHINGTON, D.C. 20013

$\underline{\mathrm{CEC}}$

Dr. H. EHRINGER

CEC, DG XII

200 rue de 1 a Loi

B-1049 BRUXELLES

OECD

SECRETARIAT

Mr. N. DE TERRA

IEA 
Appendix $B$

IMPLEMENTING AGREEMENTS 
INTERNATIONAL ENERGY AGENCY

IMPLEMENTING AGREEMENT

FOR A PROGRAMME. OF RESEARCH

AND DEVELOPMENT

ON ENERGY CONSERVATION IN BUILDINGS

AND COMMUNITY SYSTEMS 
INTERNATIONAL ENERGY AGENCY

IMPLEMENTING AGREEMENT FOR A PROGRAMME OF RESEARCH AND DEVELOPMENT ON ENERGY CONSERVATION IN BUILDINGS AND COMMUNITY SYSTEMS

TABLE OF CONTENTS

PREAMBLE

Aricle I

OBJECTIVES

Aricle ?

IDENTIFICATION ANO INITIATION OF TaSkS

Article 3

The Executive Comaittee

Arricle $t$

The Operativg henents

Arric!e 5

ADMINISTRATION AND Stiff

Aricle 6 
Aricle 7

INFORMATION aND INTELIECTLAL PROPERTY

13

Article $\$$

LEGAL RESPONSIBILITY ANO INSSLRANCE

14

Article 9

Legislative Provisions

14

Arricle 10

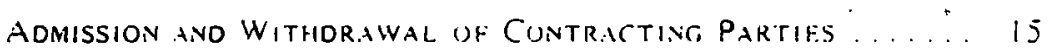

Arricle 11

Final Provisions

ANVEXI

ESTABLISHMENT OF METHOOOLUGILS FOR LOAD ENERGY DETERMINATION OF BUILDINGS. 


\section{IMPLEMENTING AGREEMENT \\ FOR A PROGRAMME OF RESEARCH AND DEVELOPMENT \\ ON ENERGY CONSERVATION IN BUILDINGS AND COMMUNITY SYSTEMS}

The Contracting Purties

Considerivg that the Contracting Parties, being either governments or international organisations or parties designated by their respective governments pursuant to Article III of the Guiding Principles for Co-speration in the Field of Energy Research and Development adopted by the Governing Board of the International Energy Agency (the "Agency") on 28th July. 1975. wish to take part in the establishment and operation of a Programme of Research and Development on Energy Conservation in Buildings and Community Systems (the "Programme") as provided in this Agreement;

Considering that the Contracting Parties which are governments and the governments of the other Contracting Parties (referred to collectively as the "Governments"). participate in the Agency and have agreed in Article +1 of the Agreement on an International Encrgy Program (the "I.E.P. Agreement") to undertake national programmes in the areas set out in Article +2 of the I.E.P. Agreement. including research and development on energy conservation in which held the Programme will be carried out:

CONSIDERING that in the Governing Board of the Agency on 28th July. 1975 the Governments approved the Programme as a special activity under Article 65 of the I.E.P. Agreement: 
Considering that the Agency has recognised the establishment of the Programme as an important component of international co-operation in the field of energy conservation research and development;

HAVE AGREED as follows:

\author{
Article 1
}

\title{
OBJECTIVES
}

(a) Scope of Activity. The Programme to be carried out by the Contracting Parties within the framework of this Agreement shall consist of co-operative research. development. demonstrations and exchanges of intormation regarding energy conservation in buildings and community systems.

(b) Method of Implementation. The Contracting Parties shall implement the Programme by undertaking one or more tasks (the "Task" or "Tasks") each of which will be open to participation by two or more Contracting Parties as previded in Article 2 hereot. The Contracting Parties which participate in a particular Task are. tor the purposes of that Task. referred to in this Agreement as "Participants".

(c) Task Co-ordination and Co-operation. The Contracting Parties shall cooperate in co-ordinating the work of the various Tasks and shall endeavour. on the basis of an appropriate sharing of burdens and benefits. to encourage co-operation among Participants engaged in the various Tasks with the objective of advancing the research and development activities of all Contracting Parties in the field of energy conservation in buildings and community systems.

\section{Article 2}

\section{IDENTIFICATION AND INITIATION OF TASKS}

(a) Identification. The Tasks undertaken by Participants are identified in the Annexes to this Agreement. At the time of signing this Agreement, each Contracting Party shall confirm its intention to participate in one or more Tasks by giving the Executive Director of the Agency a Notice of Participation in the relevant Annex or Annexes and the Operating Agent for each Task shall give the Executive Director of the Agency a Notice of Acceptance of the Task Annex. Thereatier. each Task shall be carried out in accordance with the procedures set forth in Articles 2 to 11 hereot. unless orherwise specifically provided in the applicable Annex.

(b) Initiation of Additional Tasks. Additional Tasks may be initiated by any Contracting Party according to the following procedure: 
(1) A Contracting Party wishing to initiate a new Task shall present to one or more Contracting Parties for approval a draft Annex. similar in form to the Annexes attached hereto. containing a description of the scope of work and conditions of the Task proposed to be performed:

(2) Whenever two or more Contracting Parties agree to undertake a new Task, they shall submit the draft Annex for approval by the Executive Committee pursuant to Article 3 (e) (2) hereot; the approved draft Annex shall become part of this Agreement: Notice of Participation in the Tusk by Contracting Parties and acceptance by the Operating Agent shall be communicated to the Executive Direciur in the manner provided in paragraph (a) above;

(3) In carrying out the various Tasks, Participants shall co-ordinate their activities in order to avoid duplication of activities.

(c) Application of Task Annexes. Each Annex shall be binding only upon the Participants therein and upon the Operating Agent for that Task. and shall not affect the rights or obligations of other Contracting Parties.

\section{Article 3}

\section{THE EXECUTIVE COMMITTEE}

(a) Supervisory Control. Control of the Programme shall be vested in the Executive Committee constituted under this Article.

(b) Membership. The Executive Committee shall consist of one member designated by each Contracting Party; each Contracting Party shall also designate an alternate member to serve on the Executive Committee in the event that its designated member is unable to do so.

Responsibilities. The Executive Committee shull:

(1) Adopt for each year, acting by unanimity, the Programme of Work. and Budget if foreseen. for each Task. together with an indicative programme of work and budget for the following two years: the Executive Committee may, as required. make adjustments within the iramework of the Programme of Work and Budget:

(2) Make such rules and regulations as may be required for the sound management of the Tasks, including financial rules as provicied in Article 6 hereof;

(3) Carry out the other functions conferred upon it by this Agreement and the Annexes hereto; and 
(4) Consider any matters submitted to it by any of the Operating Agents or by any Contracting Party.

(d) Procedure. The Executive Committee shall carry out its responsibilities in accordance with the following procedures:

(1) The Executive Committee shall each year elect a Chairman and one or more Vice-Chairmen:

(2) The Executive Committee may establish such subsidiary bodies and rules of procedure as are required for its proper functioning. A representative of the Agency and a representative of, each Operating Agent (in its capacity as such) may attend meetings of the Executive Committes and its subsidiary bodies in an advisory capacity;

(3) The Executive Committee shall meet in regular session twice each year: a special meeting shall be convened upon the request of any Contracting Party which can demonstrate the need theretor:

(4) Meetings of the Executive Committee shall be held at such time and in such office or offices as may be designated by the Committee:

(5) At least twenty-eight days betore each meeting of the Executive Committee, notice of the time, place and purpose of the meeting shall be given to each Contracting Party and to other persons or entities entitled to attend the meeting; notice need not be given to any person or antity otherwise entitled thereto if notice is waived before or after the meeting;

(6) The quorum for the transaction of business in meetings of the Executive Committee shall be one-half of the members plus one (less any resulting fraction) provided that any action relating to a particular Task shall require a quorum as aforesaid of members or alternate members designated by the Participants in that Task. If a government has designated more than one Contracting Party to this Agreement. the Executive Committee members designated by those Contracting Parties shall. tor quorum purposes under this paragraph. be counted as one member.

(e)

Voting.

(1) When the Executive Committee adopts a decision or recommendation for or concerning a particular Task, the Executive Committee shall act:

(i) When unanimity is required under this Agreement: by agreement of those members or alternate members which were designated by the Participants in that Tusk and which are present and voting:

(ii) When no express voting provision is made in this Agreement: by majority vote of those members or alternate members which were designated by the Participants in that Task and which are present and voting; 
(2) In all other cases in which this Agreement expressly requires the Executive Committee to act by unanimity, this shall require the agreement of each member or alternate member present and voting, and in respect of all other decisions and recommendations for which no express voting provision is made in this Agreement, the Executive Committee shall act by a majority vote of the members or alternate members present and voting;

(3) The decisions and recommendations referred to in paragraphs (1) and (2) above may, with the agreement of each member or alternate member entitled to act thereon, be made by mail, telex or cable without the necessity for calling a meeting. Such action shall be taken by unanimity or majority of such members as in a meeting. The Chairman of the Executive Committee shall ensure that all members are informed of each decision or recommendation made pursuant to this paragraph;

(4) If a government has designated more than one Contracting Party to this Agreement. those Contracting Parties may cast only one vote under this Article.

(f) Reports. The Executive Committee shall, at least annually, provide the Agency with periodic reports on the progress of the Programme.

\section{Article 4 \\ THE OPERATING AGENTS}

(a) Designation. Participants shall designate in the relevant Annex an Operating Agent for each Tusk. References in this Agreement to the Operating Agent shall apply to each Operating Agent in respect of the Task for which it is responsible.

(b) Scope of Authority to Act on Behalf of Participants. Subject to the provisions of the applicable Annex:

(1) All legal acts required to carry out each Task shall be pertormed on behalf of the Participants by the Operating Agent for the Task:

(2) The Operating Agent shall hold. for the benefit of the Participants, the legal title to all property rights which may accrue to or be acquired for the Task.

The Operating Agent shall operate the Task under its supervision and responsibility. subject to this Agreement, in accordance with the law of the country of the Operating Agent.

(c) Reimbursements of Costs. The Executive Committee may provide that expenses and costs incurred by an Operating Agent in acting as such pursuant to this Agreement shall be reimbursed to the Operating Agent from funds made available by the Participants pursuant to Article 6 hereof. 
(d)

Replacement. Should the Executive Committee wish to replace an Operating Agent with another government or entity, the Executive Committee may. acting by unanimity and with the consent of such government or entity. replace the initial Operating Agent. References in this Agreement to the "Operating Agent" shall include any government or entity appointed to replace the original Operating Agent under this paragraph.

(e) Resignation. An Operating Aggent shall have the right to resign at any time, by giving six months written notice to that effect to the Executive Committes. provided that:

(1) A Participant, or entity designated by a Participant. is at such time willing to assume the duties and obligations of the Operating Agent and so notifies the Executive Committee and the other Participants to that effect. in writing. not less than three months in advance of the effective date of such resignation; and

(2) Such Participant or entity is approved by the Executive Committee. acting by unanimity.

(f) Accounting. An Operating Agent which is replaced or which resigns as Operating Agent shall provide the Executive Committee with an accounting of any monies and other assets which it may have collected or acquired for the Task in the course of carrying out its responsibilities as Operating Agent.

(g) Transter of Rights. In the event that another Operating Agent is appointed under paragraph $(d)$ or (e) above. the Operating Agent shall transfer to such replacement Operating Agent any property rights which it may hold on behalf of the Task.

Arricle 5

ADMINISTRATION AND STAFF

(a) Administration of Tusks. Each Operating Ayent shall be responsible to the Executive Committee for implementing its designated Task in accordance with this Agreement, the applicable Task Annex, and the decisions of the Executive Committee.

(b) Information and Reports. Each Operating Agent shall furnish to the Executive Committee such information concerning the Task as the Committee may request and shall each year submit. not later than two months after the end of the financial year. a report on the status of the Task.

(c) Staff. It shall be the responsibility of the Operating Agent to retain such staff as may be required to carry out its designated Task in accordance with rules determined by the Executive Committee. The Operating Aigent may also, as required, utilise the services of personnel employed by other Participants (or organisations or other entities designated by Contracting Parties) and made available to the Operating Agent by secondment or otherwise. Such personnel shall be remunerated by their respective employers 
and shall. except as provided in this Article. be subject to their employers conditions of service. The Contracting Parties shall be entitled to claim the appropriate cost of such remuneration or to receive an appropriate credit for such cost as part of the Budget of the Task. in accordance with Article $6(f) \cdot(6)$ hereot.

\section{Article 6 \\ FINANCE}

(a) Individual Obligations. Each Contracting Party shall bear the costs it incurs in carrying out this Agreement. including the costs of formulating or trunsmitting reports and of reimbursing its employees for travel and other per diem expenses incurred in connection with work carried out on the respective Tasks. unless provision is made tor such costs to be reimbursed from common funds as provided in paragraph ( $g$ ) below.

(b) Common Financial Obligations. Participants wishing to share the costs of a particular Task shall ayree in the appropriate Task Annex to do so. The apportionment of contributions to such costs (whether in the form of cash. services rendered. intellectual property or the supply of materials) and the use of such contributions shall be governed by the regulations and decisions made pursuant to this Article by the Executive Committee.

(c) Rules of Procurement. Expenditure. The Executive Committee. acting by unanimity, may make such regulations as are required tor the sound financial management of each Task including, where necessary:

(1) Establishment of budgetary and procurement procedures to be used bv the Operating Agent in making payments from any common funds which may be maintained by Participants for the account of the Task or in making contracts on behalf of the Participants:

(2) Establishment of minimum levels of expenditure for which Executive Committee approval shall be required. including expenditure involving payment of monies to the Operating Agent for vther than routine saliary and administrative expenses previously approved by the Executivi Committee in the budget process.

In the expenditure of common funds. the Operating Agent shall take into account the necessity of ensuring a fiair distribution of such expenditure in the Participants countrics. where this is fully compatible with the most efficient technical and tinancial management of the Tusk.

(d) Crediting of Income to Budget. Any income which accrues from a Task shall be credited to the Budget of that Task.

$\because$ Accouming. The system of accounts employed by the Operating Agent hall be in accordance with accounting principles generally dccepted in the country of the Operating Agent and consistently applied. 
Programme of Work and Budget, Keeping of Accounts. Should Participants agree to maintain common tunds for the pavment of obligations under a Programme of Work and Budget of the Task. accounts shall be maintained as tollows unless orherwise decided by the Executive Committee, acting by unanimity:

(1) The financial year of the Tash shall correspond to the financial year of the Operating Agent;

(2) The Operating Agent shall each year prepare and submit to the Executive Committee for approval a dratt Programme of Work and Budget. together with an indicative programme of work and budget tor the following two years, not later than three months before the beginning of each financial year;

(3) The Operating Agent shall maintain compiete. separate financial records which shall clearly account for all tunds and property coming into the custody or possession of the Operating Agent in connection with the Task;

(4) Not later than three months after the close of each financial year the Operating Agent shall submit to auditors selected by the Executive Committee for audit the annual accounts maintained for the $T$ ask: upon completion of the annual audit. the Operating Agent shall present the accounts together with the auditors' report to the Executive Committee for approval;

(5) All books of account and records maintained by the Operating Agent shall be preserved for at least three years from the date of termination of the Task;

(6) Where provided in the relevant Annex, a Participant supplying services. materials or intellectual property to the Task shall be entitled to a credit. determined by the Executive Committee. acting by unanimity. against its contribution for to compensation. if the value of such services. materials or intellectual property exceeds the amount of the Participant's contribution): such credits for services of stalf shall be calculated on an agreed scale approved by the Executive Committee and include all payroll-related costs.

(g) Contribution to Common Funds. Should Participants agree to establish common funds under the annual Programme of Work and Budget for a Task, any financial contributions due from Participants in a Task shall be paid to the Operating Agent in the currency of the country of the Operating Agent at such times and upon such other conditions as the Executive Committee. acting by unanimity, shall determine. provided however that:

(1) Contributions received by the Operating Agent shall be used solely in accordance with the Programme of Work and Budget for the Tash; 
(2) The Operating Agent shall be under no obligation to carry out any work on the Task until contributions amounting to at least fifty per cent (in cash terms) of the total due at any one time have been received.

(h) Ancillary Services. Ancillary services may, as agreed between the Executive Committee and the Operating Agent, be provided by that Operating Agent for the operation of a Task and the costs of such services, including overheads connected therewith. may be met from budgeted funds of that Task.

(i) Taxes. The Operating Agent shall pay all taxes and similar impositions (other than taxes on income) imposed by national or local governments and incurred by it in connection with a Task, as expenditure incurred in the operation of that Task under the Budget; the Operating Agent shall, however. endeavour to obtain all possible exemptions trom such taxes.

(i) Audit. Each Participant shall have the right. at its sole cost. to audit the accounts of any work in a Task for which common funds are maintained on the following terms:

(1) The Operating Agent shall provide the other Participants with an opportunity to participate in such audits on a cost-shared basis;

(2) Accounts and records relating to activities of the Operating Agent other than those conducted for the Task shall be excluded trom such audit. but if the Participant concerned requires verification of charges to the Budget representing services rendered to the Task by the Operating Agent, it may at its own cost request and obtain an audit certificate in this respect from the auditors of the Operating Agent:

(3) Not more than one such audit shall be required in any financial year:

(4) Any such audit shall be carried out by not more than three representatives of the Participants.

Article 7

INFOR:MATION AND INTELLECTUAL PROPERTY

It is expected that for each Task agreed to pursuant to this Agreement, the applicable Annex will contain information and intellectual property provisions. The General Guide. lines Concerning Information and Intellectual Property. approved by the Governing Board of the Agency on 21 st November, 1975. shall be taken into account in developing such provisions. 


\section{LEGAL RESPONSIBILITY AND INSURANCE}

(a) Liability of Operating Agent. The Operating Agent shall use all reasonable skill and care in carrying out its duties under this Agreement in accordance with all applicable laws and regulations. Except as otherwise provided in this Article. the cost of all damage to property. and all expenses associated with claims. actions and ocher costs arising from work undertaken with common lunds for a Task shall be charged to the Budget of that Task: such costs and expenses arising trom orher work undertaken for a Task shall be charged to the Budget of that Task if the Task Annex so provides or the Executive Committee. acting by unanimity, so decides.

(b) Insurance. The Operating Agent shall propose to the Executive Committee all necessary liability. fire and other insurance. and shall carry such insurance is the Executive Committee may direct. The cost of obtaining and maintaining insurance shall be charged to the Budget of the Task.

(c) Indemnification of Contracting Parties. The Operating tyent shall be liable. in its capacity as such. to indemnify Participants atgainst the cost of any damage to property and all legal liabilities. actions. claims. costs and expenses connected therewith to the extent that they:

(1) Result from the Eailure of the Operating Agent to maintain such insurance as it may be required to maintain under para:raph (b) above: or

(2) Result from the gross negligence or wilful misconduct of any officers or employees of the Operating Agent in carrying out their duties under this Agreement.

Article 9

\section{LEGISLATIVE PROVISIONS}

(a) Accomplishment of Formulities. Each Participant shall. within the framework of applicable legislation. use its best endeavours to facilitate the accompiishment of tormalities involved in the movement of persons. the importation of materials and equipment and the transter of currency which shall be required to conduct the $T$ ust in which it is engaged.

(b) Applicable Laws. In carrying out this Agreement and its Annexes, the Contracting Parties shall be subject to the appropriation of tunds by the appropriace governmental authority. where necessary. and to the constitution. laws and regulations applicable to the respective Contracting Parties. including. but not limited to. latvs escablishing 
prohibitions upon the payment of commissions. percentages. brokerage or contingent fees to persons retained to solicit governmental contracts and upon any share of such contracts accruing to governmental officials.

(c) Decisions of Agency Governing Board. Participants in the various Tasks shall cake account, as appropriate, of the Guiding Principles for Co-operation in the Field of Energy Research and Development, and any modification thereot. as well as other decisions of the Governing Board of the Agency in that field. The termination of the Guiding Principles shall not affect this Agreement, which shall remain in force in accordance with the terms hereof.

(d)

Settlement of Disputes. Any dispute among the Contracting Parties concerning the interpretation or the application of this Agreement which is not settled by negotiation or other agreed mode of settlement. Shall be referred to a tribunal of three arbitrators to be chosen by the Contracting Parties concerned who shall also choose the Chairman of the triounal. Should the Contracting Parties concerned fail to agree upon the composition of the tribunal or the selection of its Chairman. the President of the International Court of Justice shall. at the request of any of the Contracting Parties concerned, exercise those responsibilities. The tribunal shall decide any such dispute by reterence to the terms of this Agreement and any applicable laws and regulations. and its decision on a question of fact shall be tinal and binding on the Contracting Parties. Operating Agents which are not Contracting Parties shall be regarded as Contracting Parties for the purpose of this paragraph.

Arricle 10

\section{ADMISSION AND WITHDRAWAL OF CONTRACTING PARTIES}

(a) Admission of New Contracting Parties: Agency Countries. Lipon the invitation of the Executive Committee, acting by unanimity, admission to this dgreement shall be open to the government of any Agency Participating Councry lor at national agency, public organisation. private corporation. company or other entity designated by such government), which signs or accedes to this Aigreement, accepts the rights and obligations of a Contracting Party, and is accepted for participation in at least une Task by the Participants in that Tusk. acting by unanimity. Such admission of a Contracting Party shall become effective upon the signature of this Agresment by the new Contracting Party or its accession thereto and its giving Votice of Participation in one or more Annexes and the adoption of any consequential amendments thereto.

(b) Admission of Vew Contracting Parties: Other OECD Countries. The government of any Member of the Organisation for Economic Co-operation and Development which does not participate in the Agency may, on the proposal of the Executive Committes. acting by unanimity, be invited by the Guverning Board of the Agency to become a Contracting Party to this Agreement (or to designate a national agency. public organisation. private corporation. company or other entity to do so). under the conditions stated in paragraph (a) above. 
(c) Participation by the European Communities. The European Communities may participate in this Agreement in accordance with arrangements to be made by the Executive Committee, acting by unanimity.

(d) Admission of New Participants in Tasks. Any Contracting Party may, with the agreement of the Participants in a Task. acting by unanimity, become a Participant in that Task. Such participation shall become effective upon the Contracting Party's giving the Executive Director of the Agency a Notice of Participation in the appropriate Tast Annex and the adoption of consequential amendments thereto.

(e) Contributions. The Executive Committee may require, as a condition to admission to participation. that the new Contracting Party or new Participant shall contribute (in the form of cash. services or materials) an appropriate proportion of the prior budget expenditure of any Task in which it participates.

(i) Replacement of Contracting Parties. With the agreement of the Executive Committee, acting by unanimity. and upon the request of a government. a Contrictin! Party designated by that government may be replaced by another party. In the event of such replacement, the replacement party shall assume the rights and obligations of a Contracting Party as provided in paragraph (a) above and in accordance with the procedure provided therein.

(g) Withdrawal. Any Contracting Party may withdraw trom this Agreement or from any Task either with the agreement of the Executive Committee. acting by unanimity. or by giving twelve months written Notice of Withdrawal to the Executive Director of th: Agency. such Notice to be given not less than two years after the date hereot. The withdrawal of a Contracting Party under this paragraph shall not affect the rights and obligations of the other Contracting Parties: except that. where the other Contracting Parties have contributed to common funds for a Task. their proportionate shares in the Task Budget shall be adjusted to take account of such withdrawal.

(h) Changes of Status of Contracting Party. A Contracting Party other than a government or an international organisation shall forthwith notify the Executive Committee of any significant change in its status or ownership. or of its becoming bankrupt or entering into liquidation. The Executive Committee shall determine whether any such change in status of a Contructing Party signiticantly affects the interests of the ocher Concractin! Parties: if the Executive Committee so determines. then. unless the Exccutivi Committci. acting upon the unanimous decision of the other Contracting Parties. Otherwise ingrees:

(1) That Contracting Party shall be deemed to have withdrawn from the Agreement under paragraph $(g)$ above on a date to be tixed by the Executive Committee; and

(2) The Executive Committee shall invite the government which designated that Contracting Party to designate. within at period of three months of the withdrawal of that Contracting Party, a different entity to become a Contracting Party; if approved by the Executive Committee. acting by unanimity, such entity shall become a Contracting Party with effect from the date on which it signs or accedes to this Agreement and gives the Executive Director of the Agency a Notice of Participation in one or more Annexes. 
(i)

Failure to Fulfil Contractual Obligations. Any Contracting Party which fails to fulfil its obligations under this Agreement within sixty days after its receipt of notice specifying the nature of such failure and invoking this paragraph. may be deemed by the Executive Committee, acting by unanimity, to have. withdrawn from this Agreement.

\section{Article 11}

\section{FINAL PROVISIONS}

(a) Term of Agreement. This Agreement shall remain in force for an initial period of three years from the date hereof, and shall continue in torce thereatter unless and until the Executive Committes. acting by unanimity. decides on its termination.

(b) Legal Relationship of Contracting Parties and Participants. Nothing in this Agreement shall be regarded as constituting a partnership between any of the Contracting Parties or Participants.

(c) Termination. Upon termination of this Ayreement. or any Annex to this Agreement. the Executive Committee. acting by unanimity. shall arrange for the liquidation of the assets of the Task or Tasks. In the event of such liquidation. the Executive Committee shall, so far as practicable. distribute the assets of the Task. or the proceeds theretrom, in proportion to the contributions which the Participants have made from the beginning of the operation of the Task. and for that purpose shall take into account the contributions and any outstanding obligations of former Contracting Parties. Disputes with a former Contracting Party about the proportion allocated to it under this paragraph shall be settled under Article $9(d)$ hereot, for which purpose a former Contrictin@ Party shall be regarded as a Contracting Party.

(d) Amendment. This Agreement may be amended at any time by the Executive Committee. actin@ by unanimity. and any Annicx to this Agreement maty be amended at any time by the Executive Committee. acting by unanimity of the Participants in the Task to which the Annex refers. Such amendments shall come into force in a mannor determined by the Executive Committee, acting under the voting rule applicable to tite decision to didopt the amendment.

(e) Deposit. The original of this Agreement shall be deposited with the Executive Director of the Agency and a certified copy thereot shall be furnished to dach Contracting Party. A copy of this Agreement shall be turnished to each Agency Participating Country. to each Member country of the Organisation for Economic Cu-operation and Development and to the European Communities.

one in Paris, this 16th day of Warch. 1977. 
For the National Research

Council of Canada

(designated by the Government

of Canada):

For the Consiglio Nazionale

DELLE RICERCHE

(designated by the Government

of Italy):

For the Office Féderal de la Science

ET DE LAA RECHERCHE

DU DÉPartevent FÉdÉRAL DE L'INTÉRIEUR

for and on behalf of the Government

ot Switzeriand:

For Atkins Research and Development idesignated by the Government of the Lnited Kingdom of Great Britain and Vorthern [reland):

For HADEN YOUNG LTD.

(designated by the Government of the United Kingdom of Great Britain and Vorthern Ireland):

For Oscar Faber aivo Partivers (designated by the Government of the United Kingdom of Great Britain and Northern [reland):

For Pilkington Bros. Lto. idesignated by the Govemment of the United Kingdom of Greas Britain and Northern Ireland):

For the UNited States Evergy Research AND DEVELOPMENT ADMINISTRATION for and on behalf of the Government of the Lnited States of America: 


\section{ESTABLISHMENT OF METHODOLOGIES FOR LOAD/ENERGY DETERMINATION OF BUILDINGS}

\section{1. Öbjectives}

The objective of this Task is to provide for surveyin!. collecting and evaluating analytical methods used for predicting loads and energy consumption for buildings. The Task will provide comparisons of the results of the various methods to determine the degree of consistency obtained.

It also will be an objective of the Task to provide Participants with the opportunity to interface with the U.S. Lawrence Berkeley Laboratory (LBL) System. when that system becomes operable. in order to allow ongoing evaluation and comparison of systems they themselves have developed or have under investigation.

\section{Means}

The Participants will undertake a task-sharing project involving Jata gathering, analysis of results and participation in the LBL System.

\section{Responsibilities of the Participants and the Operating Agent}

\section{(a) Responsihilities of the Participants}

The work performed under this Task shall consist of three subtasks:

Subtask 1: Gather Data-Each Participant will survey and collect and submit to the Operating. Agrent analytical methods that are being used for predicting the annual energy consumption of a specific building design. or for selecting and sizing equipment for the building. Additionally, important methods being used for research will also be submitted.

Subtask 2: Determine Consistenry of Results-Once the results of the surveys in Subcask 1 hive been received. the Operating Agent. with the assistance of the Participants, will conduct analyses to determine to what degree consistency exists between the various techniques and the LBL System.

Subtask 3: Transmittal of Results and Access to LBL System-Aiter analysis of the data submitted to the Participants under Subtask 2, the Operating Agent will transmit the information obtained thereby to the Participants. The Operating Agent will take steps to permit the Participants' access to the LBL System for the period this Task Annex remains in force. Two Participants, Canada and the United Kingdom. will link their systems activities with the LBL System to provide an analytical research service to all Participants. 


\section{(b) Specific Duties of the Operating Agent}

Within ninety days following the entry into force of this Annex. the Operating Agent will prepare a comprehensive work plan as well as a survey format for submission to the Executive Committee for its approval. acting by unanimity.

\section{Funding}

Each Participant shall individually bear the costs associated with the execution of Subtasks 1, 2 and 3.

\section{Time Schedule}

This Task Annex will remain in force for a period of three years. It may be extended by agreement of any Participants desiring to continue this project.

\section{Operating Agent}

United States Energy Research and Development Administration.

\section{Information and Intellectual Property}

(a) Executive Committee's Powers. The publication, distribution. handling. protection and ownership of intormation and intellectual property arising from this Annex $l$ to the IEA Implementing Agreement for a Programme of $R$ and $D$ on Energy Conservation in Buildings and Community Systems (hereinafter called Annex /) shall be determined by the Executive Com. mittee, acting by unanimity. in coniormity with this Agreement.

(b) Right to Publish. Subject only to copyright restrictions, the Annex I Participants shall have the right to publish all information provided to or arising from Annex $l$ except proprietary intormation.

(c) Proprietary Information. The Annex I Participants shall take all necessary measures in accordance with this paragraph. the laws of their respective countries and international law to protect proprietary information. For the purposes of this Annex, proprietary information shall mean information of a confidential nature such as trade secrets and know-how (for example, computer programmes, design procedures and techniques. chemical com. position of materials. or manufacturing methods, processes. or treatments) which is appropriately marked. provided such information:

(1) Is not generally known or publicly available from other sources:

(2) Has not previously been made available by the owner to others without obligation concerning its confidentiality; or

(3) Is not already in the possession of the recipient Annex I Participant without obligation concerning its confidentiality. 
It shall be the responsibility of each Participant supplying proprietary information to identify the information as such and to ensure that it is appropriately marked.

(d) Production of Relevant Information by Governments. The Operating Agent should encourage the governments of all Agency Participating Countries to make available or to identify to the Operating Agent all published or otherwise freely available information known to them that is relevant to the Task.

(e) Production of Available Information by Participants. Each Participant agrees to provide to the Operating Agent all previously existing information. and information developed independently of the Tusk. which is needed by the Operating Agent to carry out its functions in this Task and which is freely at the disposal of the Participant and the transmission of which is not subject to any contractual and/or legal limitations:

(1) If no substantial cost is incurred by the Participant in making such information available. at no charge to the Task therefor:

(2) If substantial costs must be incurred by the Participant to make such information available, at such charges to the Task as shall be agreed between the Operating Agent and the Participant with the approval of the Executive Committee.

(f) Use of Confidential Information. If a Participant has access to confidential information which would be useful to the Operating Agent in conducting studies. assessments, analyses. or evaluations. such information may be communicated to the Operating Agent but shall not become part of reports or other documentation. nor be communicaled to the other Participants except as may be agreed between the Operating Agent and the Participant which supplies such intormation.

(g) Acquisition of Information for the Task. Each Participant shall inform the Operating Agent of the existence of intormation that can be of value to the Task. but which is not freely available, and the Participant shall endeavour to make the information available to the Task under reusonable conditions, in which event the Executive Committee may, acting by unanimity. decide to acquire such information.

(h) Reports on Work Performed under the Task. The Operating Agent shall provide reports of all work performed under the Task and the results thereof. including studies. assessments, analyses. evaluations and other documentation, but excluding proprietary intormation, to the Executive Committee.

(i) Copyright. The Executive Committee. or any member appointed by it. may take appropriate measures necessary to protect copyrightable material generated under this Task. Copyrights obtained shall be the property of the Operating Agent, provided, however, that Annex I Participants may 
reproduce and distribute such material. but shall not publish it with a view to profit, except as otherwise directed by the Executive Committee.

(i) Authors. Each Annex / Participant will. without prejudice to any rights of authors under its national laws. take necessary steps to provide the co-operation from its authors required to carry out the provisions of this Article. Each Amner / Participant will assume the responsibility to pay awards or compensation required to be paid to its employees according to the laws of its country.

8. Participants in this Task

The Contracting Parties which are Participants in this Task are the following:

The National Research Council of Canada (Canada)

The Consiglio Nazionale delle Ricerche (Italy)

The Office Fédéral de la Science et de la Recherche du Département

Fédéral de l'Intérieur (Sivitzerland)

Atkins Research and Development (UK)

Haden Young Lid. (LK)

Oscar Faber and Partners (UK)

Pilkington Bros. Lid. (UK)

The United States Energy Research and Development Administration (United States of America) 
INTERNATIONAL ENERGY AGENCY

IMPLEMENTING AGREEMENT

FOR A PROGRAMME OF RESEARCH

AND DEVELOPMENT

ON ENERGY CONSERVATION

IN COMBUSTION 


\section{IMPLEMENTING AGREEMENT \\ FOR A PROGRAMME OF RESEARCH AND DEVELOPMENT ON ENERGY CONSERVATION IN COMBUSTION.}

TABLE OF CONTENTS

Preamble

Article $l$

OBJECTIVES

Aricle?

The Executive Committee

Article $j$

The Operating heevt

Article 4

ADMINISTRATION tiNo STAFF

Article : 
Article 6

Information and Intellectual Property

Article 7

LEGAL Responsibility

Aricle $S$.

Legislative Provisions

Arricle 9

admission and Withdrawal of Contracting Parties .....

Aricle 10

Final Provisions

$$
\text { ANVEX }
$$

Energy Conservition in COMBUStion 


\section{IMPLEMENTING AGREEMENT \\ FOR A PROGRAMME OF RESEARCH \\ AND DEVELOPMENT \\ ON ENERGY CONSERVATION \\ IN COMBUSTION}

The Contracting Parties

ConsIderinc that the Cuntracting Parties. being either governments or international organisations or parties designated by their respective governments pursuant to Article III of the Guiding Principles for Co-operation in the Field of Energy Research and Development adopted by the Governing Board of the Internitional Energy Agency (the "Agency") on 28th July. 1975. wish to take part in the escablishment and operation of a Programme of Research and Developmenc on Energy Conservation in Combustion (the "Programme") as provided in this torreement:

CONSIDERING that the Contracting Parties which are governments and the governments of the other Contracting Parties (reterred to collectively as the "Governments") participate in the Agency and have agreed in Article +1 of the Agreement on an International Energy Program (the "I.E.P. Agreement") to undertake national programmes in the areas set out in Article +2 " if the I.E.P. Agrcement. including research and development on energy conservation in which field the Programme will be carried out:

Considering that in the Governing Bourd of the Agency on 16th Warch. 1977. the Governments approved the Programme als a special activity under Article 65 of the I.E.P. Agreement: 
CONSIDERING that the Agency has recognised the establishment of the Programme as an important component of international co-operation in the field of energy conservation research and development;

HAVE AGREED as follows:

\section{Article 1}

\section{OBJECTIVES}

(a) Scope of Activity. The Programme to be carried out by the Contracting Parties within the tramework of this Agreement shall consist of co-operative research. development, demonstrations and exchanges of intormation regarding combustion.

(h) Method of Implementation. Each Contracting Party shall implement the Programme by undertaking one or more Tasks as provided in the attached Annex.

(c) Task Co-ordination and Co-operation. The Contracting Parties shall cocperate in co-ordinating the work of the various Tasks in the altached Annex and in advancing the research and develupment activities of all Contracting Parties in the field of energy conservation.

(1) Additional Tusks. Additional Tasks may be joined to the Programme by amendment of the attached Annex to this Agreement as provided in Article 10 (c) hereto.

Article ?

\section{THE EXECUTIVE COMMITTEE}

(a) Supervisory Control. Control of the Programme shall be vested in the Executive Committee constituted under this Article.

(b) Membership. The Executive Committee shall consist of one member designated by each Contracting Party; each Contracting Party shall also designate an alternate member to serve on the Executive Committee in the event that its designated member is unable to do so.

(c) Responsibilities. The Executive Committee shall:

(1) Adopt lor each year, acting by unanimity. the Programme of Work for the Tasks of the attached Annex, together with an indicative programme of work for the following two years; the Executive Committee may, as 
required. make adjustments within the framework of the Programme of Work;

(2) Make such rules and regulations as may be required for the sound management of the Tasks:

(3) Carry out the other functions conferred upon it by this Agreement and the Annex hereto: and

(4) Consider any matters submitted to it by the Operating Agent or by any Contracting Party.

(d) Procedure. The Executive Committee shall carry out its responsibilities in accordance with the following procedures:

(1) The Executive Committee shall each vear elect a Chairman and one or more Vice-Chairmen:

12) The Executive Committee may establish such subsidiary bodies and rules of procedure as are required for its proper iunctioning. A representative of the Agency may attend meetings of the Executive Committee and its subsidiary bodies in an advisory capacity:

(3) The Executive Committee shall meet in regular session twice each year: a special meeting shall be convened upon the request of any Contracting Party which can demonstrate the need theretor:

(4) Meetings of the Executive Committee shall be held at such time and in such otfice or offices as may be designated by the Committee:

15) At least twenty-eight days before each meeting of the Executive Committee. notice of the time. place and purpose of the meeting shall be given to each Contracting Party and to other persons or entities entitled to attend the meeting: notice need not be given to any person or entity otherwise enticled thereto if notice is ivailed before or alter the meeting:

(6) The quorum for the transaction of business in meetings of the Executive Committee shall be one-half of the members plus one lless any resulting fraction).

Voting.

(1) Where this Agreement requires the Executive Committee to at by unanimity. this shall require the agreement of each member or alternate member present and voting at the meeting at which the decision is taken. The Executive Committee shall adopt decisions and recom. mendations. for which no express roting provision is made in this Agrement. by majority vote of the members or alternate members present and voting; 
(2) With the agreement of each Contracting Party a decision or recommendation may be made by telex or cable without the necessity for calling a meeting. The Chairman of the Executive Committee shall have the responsibility of ensuring that all Contracting Parties are informed of each decision or recommendation made pursuant to this paragraph.

(i) Reports. The Executive Committee shall. at least annually, provide the Agency with periodic reports on the progress of the Programme.

Article 3

THE OPERATING AGENT

(a) Designation. An Operating Agent is designated in the Annex hereto.

(b) Scope of Authority to Act on Behalf of Contracting Parties. Subject to the provisions of Article 6 hereof. the Operating Agent shall perform all legal acts required to carry out its tunctions as defined in the Annex hereto.

(c) Replacement. A Contracting Party midy, with the consent of the Executive Committee. acting by unanimity. designate another entity as Operating Agent in place of the Contracting Party or other Operating Agent designated by it. The adoption of any consequential amendments to this Agreement and the Annex hereto as well as the arrangeinents tor transter of the Operating Agent's responsibilities shall require a decision or the Executive Committee, acting by unanimity.

(d) Resignation. The Operating Agent shall have the right to resign at any time. by giving six months written notice to that effect to the Executive Committee. provided that:

11) A Contracting Party. or entity designated by a Contracting Party. is at such time willing to assume the duties and obligations of the Operating Agent and so notities the Executive Committee und the other Cuntracting Parties to that effect. in writing. not less than three months in advance of the effective date of such resignation: and

(2) Such Contracting Party or entity is approved by the Executive Committee, acting by unanimity. 
Article 4

\section{ADMINTSTRATION ANU SIAHF}

(a) Administration of Tasks. The Operating Agent shall be responsible to the Executive Committee for implementing its responsibilities in acccrdance with this Agree ment, the Annex hereto and the decisions of the Executive Committee.

(b) Information and Reports. The Operating tigent shall furnish to the Executite Committee such intormation concerning the Annex hereto is the Cummittee may request and shall each year submit. not later than two months arter the end ot the financial vear. a report on the status of the Annex hereto.

(c) Staff. It shall be the responsibility of the Operating Agent to retain such staff as may be required to carry out its responsibilities in accordance with rules determined by the Executive Committee. The Operating Agent may ulso. as required. utilise the services of personnel employed by other Concracting Parties for organisations or other entities designated by Contracting Parties) and made available to the Operating Agent by secondment or otherwise. subject to urrangements to be dgreed between the Contracting Party and the employer of such personnel.

\section{Article 5}

FINANCE

(a)

Research Costs.

(1) Each Contracting Party shall be responsible for providing the rinancial resources necessary to carry out its research responsibilities under the Annex hereto. It is anticipated that the total funds expended in support of such research shall approximale \$1.300.000. based on iVarch, 1977 price levels and exchange rates. for the three year period. The Contracting Parties minimum contributions io research under the Programme shall be as follows:

First Year

(CY 1977)

NE

SwK 50.000

UKAEA $£ 55.000$

USERDA
Secund Year

(CY 1978)

SwK $\begin{array}{r}100.000 \\ \pm 77.000 \\ 5+20.000\end{array}$
Third Year

(CY 1979)

SwK 120.000

El 10.000

$\$ 600.000$ 
(2) The Executive Committee. acting by unanimity, shall adjust the figures referred to in this paragraph at half-yearly intervals to take account of changing price levels in the country of each Contracting Party to ensure that the necessary real resources will continue to be available to conduct the work called for. If significant changes in such price levels occur. the Executive Committee. acting by unanimity. shall consider whether to adjust the Programme of Work to the available funds:

(3) After the initial three-year perind and any succeeding three-year period. the Executive Committee shall. acting by unanimity. agree upon the levels of expendicure referred to in sub-paragraph (1) above tor each succeeding three-year period.

(h) Other Costs. Each Contracting Party shall also bear all other costs it incurs in carrying out this Agreement. including the costs of formulating or transmitting reports and of reimbursing its emplovees for travel and other per diem expenses incurred in connection with work carried out on the respective Tasks.

(c) Financial Statement. Not later than three months after the close of each financial year each Contracting Party shall submit to the Executive Committee a detailed financial statement concernin Contracting Party shall make ivailable such additional financial intormation on expenditure for the Task as the Executive Committee may reasonably request in order to ensure that each Task is being carried out in accordance with this Agreement.

Article 6

INFORMATION AND INTELLECTUAL PROPERTY

(a) Execurive Comminte's Powers. The publication. distribution. handling. protection and ownership of intormation and intellectual property arising from activities conducted under this Agreement shall be determined by the Executive Committee, acting by unanimity. in contormity with this Agreement.

(b) Right to Publish. Subject only to patents and copyright restrictions of this Agreement, the Contracting Parties shall have the right to publish all intormation provided to or arising from the Proyramme except proprietary information. but they shall not publish it with a view to profit except as the Executive Committee. acting by unanimity, may agree or provide by rule. All that information shall be availuble without charge to the Contracting Parties.

(c) Proprietary Intormation. The Contracting Parties shall take all necessary neasures in accordance with this Article. the laws of their respective countries and international law to protect proprietary intormation. For the purposes of this Agreement. proprietary information shall mean information of a confidential nature such as irade secrets and know-how (for example, computer programmes. design procedures and 
techniques, chemical composition of materials. or manufacturing methods. processes. or treatments) which is appropriately marked, provided such information:

(1) Is not generally known or publicly available from other sources:

(2) Has not previously been made available by the owner to others without obligation concerning its confidentiality; and

(3) Is not already in the possession of the recipient Contracting Parties without obligation concerning its confidentiality.

It shall be the responsibility of each Contracting Party supplying proprietary information to identify the information as such and to ensure that it is appropriately marked.

(d) Production of Relevant Information by Governments. The Operating Agent should encourage the governments of all Agency Participating Countries to make available or to identify to the Operating Agent all published or otherwise freely available intormation known to them that is relevant to the Tasks in the attached Annex. The Contracting Parties should notify the Operating Agent of all pre-existing intormation. and intormation developed independently of the Tash's known to them which is relevant to the Tasks and which can be made available to the Tasks without contractual or legal limitations.

(e) Reports on Programme Work. Reports containing arising intormation and pre-existing information necessary for and used in each Task. including proprietary information. shall be provided to each Contracting Party by the Contracting Party pertorming the Task. It shall be the responsibility of each Contracting Party to identify information which qualifies as proprietary information under this Article and ensure that it is appropriately marked. The Operating Agent shall provide summary reports of work periormed under the Annex hereto and the results thereof (arising information), other than proprietary intormation. to the Executive Committee.

(f) License of Proprietary Information. Each Contracting Party agrees to license all pre-existing proprietary information necessary for and used in its own Task which it owns or controls and all arising proprietary intormacion to the Contracting Parties. their governments, and the nationals of their respective countries designated by them:

(1) Royalty-iree for use in their country.only: and

(2) On reasonable terms and conditions for use in all other countries.

Each Contracting Party agrees to license all such arising proprietary information to all Agency Participating Countries on reasonable terms and conditions for use in their own country in order to meet their energy needs.

(g) License of Patents Veeded for Task. Patents solely owned or controlled by a Contracting Party which are needed for use in each Task shall be licensed to the Task Contracting Party for use in the Tusk only at no cost to such Contracting Party. if such patents are partially owned or controlled by a Contracting Party, then efforts shall 
be made by the Contracting Party to reduce or eliminate as possible the benefit that might accrue to it.

(h) Arising Inventions. Inventions made or conceived in the course of or under any Task (arising inventions) shall be owned in all countries by the inventing Contracting Party. Information regarding inventions on which patent protection is to be obtained by the Contracting Party shall not be published or publicly disclosed by the other Contracting Parties until a patent application has been filed. provided. however. that this restriction on publication or disclosure shall not extend beyond six months from the date of receipt of such information. It shall be the responsibility of the inventing Contracting Party to appropriately mark reports which disclose inventions that have not been appropriately protected by the filing of a patent application.

(i) License of Inventions. Each Contracting Party agrees to license all preexisting inventions covered by patents owned or controlled by it which are necessary for practising the results of its Task and which have been utilised in the Task, and all arising inventions to the Contracting Parties. their governments and the nationals of their respective countries designated by them:

(1) Royalty-free for use in their country only; and

(2) On reasonable terms and conditions for use in all other countries.

Each Contracting Party aggrees to license all such arising inventions to all Agency Participating Countries on reasonable terms and conditions for use in their own country in order to meet their energy needs.

(i) Copyright. The Operating Agent or each Contracting Party for its own Task results may take appropriate measures necessary to protect copyrightable material generated under any Task. Copyrights obtained shall be the property of that Contracting Party or the Operating Agent. provided. however. that Contracting Parties may reproduce and distribute such material. but shall not publish it with a view to profit.

(k) Inventors and Authors. Each Contracting Party will, without prejudice to any rights of inventors or authors under its national laws. take all necessary steps tc provide the co-operation from its authors and inventors required to carry out the provisions of this Article. Each Contracting Party will assume the responsibility to pay awards or compensation required to be paid to its emplnyees according to the laws of its country.

1) Determination of ":Vationul". The Contracting Parties may establish guidelines to determine what constitutes a "national" of a Contracting Party. Disputes that cannot be settled by the Contracting Parties shall be settled under Article $S(d)$ of this Implementing Agreement.

\section{Article 7}

\section{LEGAL RESPONSIBILITY}

No Cuntracting Party shall be liable to compensate or contribute to any other Contracting Party for any loss or damage suffered in the course of carrying out the Programme. 


\section{LEGISLATIVE PROVISIONS}

(a) Accomplishment of Formalities. Each Contracting Party shall. within the framework of applicable legislation. use its best endeavours to tacilitate the accomplishment of formalities involved in the movement of persons. the importation of materials and equipment and the transfer of currency which shall be required to conduce any $T$ ask or Tasks in which it is engaged.

(b) Applicable Laws. In carrying out this Agreement and the various Tasks in the Annex hereto, the Contracting Parties shall be subject to the appropriation of funds by the appropriate governmental authority. where necessary. and to the constitution. laws and regulations applicable to the respective Contracting Parties. including. but not limited to. laws establishing prohibitions upon the payment of commissions. percentages. brokerage or contingent fees to persons retained to solicit governmental contracts and upon any share of such contracts accruing to government otficials.

(c) Decisions of Agency Governing Bourd. The Contracting Parties shall cake account. as appropriate. of the Guiding Principles tor Co-operation in the Field of Energy Research and Development. and any modification thereot. as well as other decisions of the Governing Board of the Agency in that field. The termination of the Guiding Principles shall not affect this Agreement. which shall remain in torce in accordance with the terms hereot.

(d) Settlement of Disputes. Any dispute among the Contracting Parties concerning the interpretation or the application of this Agreement which is not settled by negotiation or other agreed mode of settlement. shall be referred to a tribunal of three arbitrators to be chosen by the Contracting Parties concerned who shall also choose the Chairman of the tribunal. Should the Contracting Parties concerned fail to agree upon the composition of the tribunal or the selection of its Chairman. the President of the International Court of Justice shall. at the request of any of the Contracting Parties concerned. exercise those responsibilities. The tribunal shall decide any such dispute by reterence to the terms of this Agreement and any applicable laivs and regulations. and its lecision on a question of tact shall be final and binding on the Cuntracting Parties.

\section{Article 9}

\section{ADMISSION AND WITHDR.AWAL OF CONTR.ACTING PARTIES}

(a) Admission of Vesv Contractins Parrics: Agenc: Countries. Lipon the invitation of the Executive Committee. acting by unanimity. admission to the Agreement shall be open to the government of any Agency Participating Country lor a national agency. public organisation. private corporation. company or other entity designated by such government), which signs or accedes to this Agreement. accepts the rights and obligations of a 
Contracting Party and agrees to carry out at least one Task defined in the Annex hereto. Such admission of a Contracting Party shall become effective upon the signature of this Agreement by the new Contracting Party or its accession thereto and the adoption of any consequential amendments thereto.

(b) Admission of Vew Contracting Parties: Other OECD Couniries. The government of any Member of the Organisation for Economic Co-operation and Development which does not participate in the Agency may. on the proposal of the Executive Committee. acting by unanimity. be invited by the Governing Board of the Agency to become a Contracting Party to this Agreement (or to designate a national agency, public organisation. private corporation. company. or other entity to do so). under the conditions stated in paragraph (a) above.

(c) Participation by the European Communities. The European Communities may participate in this Agreement in accordance with arrangements to be made by the Executive Committee. acting by unanimity.

(d) Contributions. The Executive Committee may require. as a condition to admission to participation. that the new Contracting Party accept obligations which are designed to compensate the Contracting Parties as appropriate for their prior contributions to the Programme.

(e) Replacement of Contracting Parties. With the agreement of the Executive Committee. acting by unanimity. and upon the request of a government. a Contracting Party designated by that government may be replaced by another party. In the event of such replucement. the replacement party shall assume the rights and obligations of a Contracting Party as provided in paragraph (a) ibove and in accordance with the procedure provided therein.

(f) Withdrawal. Any Contracting Party may withdraw from this Agreement either with the agreement of the Executive Committee, acting by unanimity. or by giving tivelve months written Notice of Withdrawal to the Executive Director of the Agency, such Votice to be given not less than two years after the date hereot. The withdrawal of a Contracting Party under this paragraph shall not affect the rights and obligations of the other Contracting Parties.

(g) Change of Status of Contracting Party. A Contracting Party other than a government or an international organisation shall torthwith notify the Executive Committee of any significant change in its status or ownership, or of its becoming bankrupt or entering into liquidation. The Executive Committee shall determine whether any such change in status of a Contracting Party significantly affects the interests of the other Contracting Parties; if the Executive Committee so determines, then. unless the Executive Committee, acting upon the unanimous decision of the other Contracting Parties, otherwise agrees:

(1) That Contracting Party shall be deemed to have withdrawn from the Agreement under paragraph ( $f$ ) above on a date to be fixed by the Executive Committes: and

(2) The Executive Committee shall invite the government which designated that Contracting Party to designate. within a period of three months of the withdrawal of that Contracting Party, a different entity to become 
a Contracting Party; if approved by the Executive Committee. acting by unanimity. such entity shall become a Contracting Party with effect from the date on which it signs or accedes to this Agreement.

(h) Failure to Fulfil Contractual Obligations. Any Contracting Party which fails to fulfil its obligations under this Agreement within sixty days after its receipt of notice specifying the nature of such tailure and invoking this paragraph. may be deemed by the Executive Committee, acting by unanimity. to have withdrawn from this Agreement.

Article 10

\section{FINAL PROVISIONS}

(a) Term of Agreement. This Agreement shall remain in force for an inicial period of three years from the date hereof. and shall continue in force thereafter unless and until the Executive Committee, acting by unanimity. decides on its termination.

(b) Legal Relationship of Contracting Parties. Nothing in this Agreement shall be regarded as constituting a partnership between any of the Contracting Parties.

(c) Amendment. This Agreement and the Annex hereto may be amended at any time by the Erecutive Committee. acting by unanimity. Such amendments shall come into force in a manner determined by the Executive Committee, acting by unanimity.

(d) Deposit. The original of this Agreement shall be depusited with the Executive Director of the Agency and a certitied copy therent shall be furnished to each Contracting Party. A copy of this Agreement shall be lurnished to each Agency Participating Country. to each Member country of the Organisation for Economic Co-operation and Development and to the European Communities.

Done in Paris, this 16th day of March. 1977. 
For the National SWEDISH BOaRd FOR ENERCY SOURCE DEVELOPMENT (NE)

(designated by the Government of Sweden):

For the Linited KINGdom Atomic ENERGY AUTHORITY (UKAEA) (designated by the Government of the United Kingdom of Great Britain and Northern Ireland):

For the Uinited States Energy Research ano Development administration (LSERDA) for and on behaif of the Government of the Linited States of America: 
$A N$ NEX

\section{ENERGY CONSERVATION IN COMBUSTION}

\section{Objectives}

\section{(a) General Objectives}

This programme has been planned to improve the information. instrumentation. and calculating procedures which are available for use by the designers. users and tabricators of combustion equipment. The ultimate benetits will be combustion equipment which is more atficient and capable of utilising alternate fue!s. This co-operative project is intended to achieve the above objectives while minimising duplication of research effort.

\section{(b) Specific Objectives}

The objectives of the work in the three areas of investigation are as follows:

\section{(1) Combustion System Modelling}

The objective of this work is the joint development of combustion technology. both analytical and experimental, which is directed toward providing predictive design capabilities for internal combustion engines and for furnaces. The long range programmes on engines (in the United States) and furnaces (in the United Kingdom) will be co-ordinated to provide maximum communication of achievements and minimum duplication of effort.

\section{2) Instrumentarion and Studies of Fundamental Processes in Combustion}

The first objective of this work is to develop inscruments and experimental techniques for the measurement of fundamental parameters and properties of combustion systems. The second objective is co carry sut theoretical investigations of the fundamental physical phenomenat of direci retevance to the combustion process. Both the experimental and theoretical work will address topics which will assist the progress of the Cumbustion System ilodelling work described in (1) above.

\section{(3) Resource Exchunge}

The objective of this work is to provide for exchanges among the Contracting Parties of resources necessary for effective implementation of combustion research programmes. Resources shall include information on objectives and results of current and past programmes. numerical analysis methods. laboratory apparatus and experimental test lacilities. 


\section{Means}

The Contracting Parties will undertake a joint research programme as defined in paragraph 3 of this Annex. involving three major areas of co-operation: Combustion System Modelling: Instrumentation and Studies of Fundamental Processes in Combustion: and Resource Exchange.

\section{Responsibilities of Contracting Purties or Participants in the Tasks}

The Tasks to be pertormed and the Responsible Participants in each area of investigation are as follows:

trea (1) Combustion System Modelling

Task (1) A: DEVELOP AND APPLY EXPERIMENTAL METHODS FOR MEASUREMIENTS IN INTERNAL COMBUSTION ENGINES

In this Task. new experimental methods will be developed and applied to measurc turbulence. velocity tields. luel-air distribution and temperature within the combustion chamber of operating engines. The USERDA is the principal contributor, providing diagnostic development in laser raman spectroscopy and laser doppler anemometry. The UKAEA will provide USERDA with special methods tor laser anemometry.

Responsible Participant: USERDA

Task I (B): DEVELOP AND APPLY VUMERICAL MODEE OF INTER. NAL COMBUSTION ENGINE PERFOR:MANCE

In this Task. a predictive numerical model will be developed iwhich will allow for two space dimensions and time variation: Subprocess models for turbulence. Uroplet combustion. chemical kinetics and ignition will be provided. This model will provide predictive capability for open chamber stratified sharge and diesel engines

Responsible Participant: USERDA

Task I (C): DEVELOP AND APPLY SYSTEM TO :MEASLRE FLRNACE TURBULENCE AND VELOCITY FIELDS

In this Task. a laser doppler anemometry system. with a water cooled probe. will be developed and used to measure turbulence and velocity fields in an experimental furnace. A uroplet measurement system will be applied to oiltired furnace medsurements.

Responsible Participant: UKAEA

Area (2) Instrumentarion and Sudies of Furdamental Processes in Combustion

Tusk 2 (A): WULTIPOINT THREE CO-ORDINATE LASER DOPPLER ANEMOMETER (LDA) DEVELOPMENT 
In this Task. a laser anemometer system will be developed for the study of turbulent tlows which will simultaneously medsure three orthogonal velocities at multiple locations and record the data for further processing. The system will initially be used to study structure phenomena in turbulent boundary layers of importance in heat transter. Thereby. important intormation will be obtained about turbulent phenomena such as bursts and sweeps and the influence of such mechanisms on turbulent convection.

Responsible Participant: NE

\section{Task 2(B): FLOW BOUNDARY CONDITION EFFECT IN TURBULENT FLOWS}

This Task will provide data to quantify the influence of boundary conditions in turbulent tlow fieids and to investigate the sensitivity of turbulence and combustion models to the choice of boundary conditions. A correlation procedure will be constructed for the description of flow boundary conditions from overall tlow parameters for use with approximate turbulence models.

Responsible Participant: UKAEA

\section{Task 2(C): SIMLLTANECLS MEASLREMENT OF DROPLET SIZE AND VELOCITY IN FLEL SPRAYS}

In this Task. a laser doppler anemometer system will be developed for measurement of droplet and gas velocity and droplet size in turbulent multiphase flows. suitable for application to the study of oil spray combustion.

Responsible Participant: UKAE.t

\section{TuSk 2(D): LDA VMEASLREMENTS OF VELOCITIES IN TIME VARYING FLOWS}

In this. Task. a laser úuppler anemumeter system will be developed for the measurement of turbulent velocity tields with time-varying mean properties in the presence of combustion. On-line dita processing will be provided to give velocity correlations as a function of time.

Responsible Participant: USERDA
Task 2(E): RAVIAN SPECTROSCOPY FOR REMIOTE MEASUREMENT OF TEMIPERATURE AND CONCENTRATION

In this Task. a laser raman spectroscopy system will be developed for the measurement of local temperature and cuncentration in burning systems with and without time variation of mein properties. This includes the development of special high power laser systems and multidimensional detection eyuipnent with time resolution adeyuate for turbulence meiasurements.

Responsible Participant: USERDA 


\section{Task 2(F): STANDARD EXPERIMENTS}

This Task is to establish a series of standard experiments against which new experimental methods and prediction models can be compared. The first phase is to identify a specitic experimental contiguration tor turbulent diffusion flow experiments. A test procedure will be devised and utilised to assure that each experimental facility contorms to the standard.

Responsible Participants: NE. UKAEA. USERDA (Task co-ordinated by Operating Agent)

Area (3) Resource Exchange

\section{Tusk j $(A)$ : COMBLSTION ABSTRACTS}

The purpose of this Task is to establish an abstracting service tor information on combustion rese:trch projects. To accomplish this purpose, the following steps will be required:

1. Definition of scope of information coverage.

2. Preparation of an abstract format.

3. Development of a collection procedure.

t. Development of a publication tormat.

5. Implementation of the service.

6. Evaluation of the initial output.

Responsible Participanes: LKAEA. USERDA

\section{Tusk 3(B): FACILITY INVENTORY}

The purpose of this Task is to develop an inventory of tacilities which can be made available to support cumbustion research programmes. Facilities shall include computers. combustion equipment. instruments and special test apparatus existing in countries of the Contracting Parties. The inventory shall include facility description. availability limitations and cost of use. The inventory shall be published as a document with provision for perindic updating. and shall be distributed (o) all Contricting Parties.

Responsible Purticipants: UKAEA. USERDA

Responsibilities of the Operuting Agent

Co-ordination amung Tasks within each areal of investigation and overall co-ordination of work between the three areas of investigation will be assured by the Operating Agent.

The Operating Agent shall be responsible for :

(a) Preparing the detailed work plans for each Task in collaboration with eilch Responsible Participant: 
(b) Ensuring that duplication of research effort is minimised;

(c) Co-ordinating the exchange of information through publications. reports. meetings and conterences: and

(d) Reporting the progress of the work under the Annex to the Executive Committee.

5. Operating Agent

United States Energy Research and Development Administration.

\section{Funding}

Funding shall be borne by the Contracting Parties in accordance with Article 5 (a) (1) of this Agreement. 
INTERNATIONAL ENERGY AGENCY

\author{
IMPLEMENTING AGREEMENT \\ FOR THE ESTABLISHMENT OF A PROJECT. \\ DEMONSTRATING ENERGY CONSERVATION \\ APPLICATIONS TO BUILDING COMPLEXES
}


Article 8

LEGaL RESPONSIBILITY AND INSURANCE

Arricle 9

Legislative Provisions

Article 10

adoition and Withdrawal of Contracting Parties

Article 11

REDUCTION OF PrograiMme

Articte 12

Final Provisions

Annexes

ANNEXE I 18

ANNEXE II 


\section{PAGES 1 to 4 WERE INTENTIONALLY LEFT BLANK}




\section{IMPLEMENTING AGREEMENT FOR THE ESTABLISHMENT OF A PROJECT DEMONSTRATING ENERGY CONSERVATION APPLICATIONS TO BUILDING COMPLEXES}

\section{The Contracting Parties}

CONSIDERING that the Contracting Parties. being either governments or parties proposed by their respective governments. pursuant to Article III of the Guiding Principles for Co-operation in the Field of Energy Research and Development adopted by the Governing Board of the Agency on 28th July, 1975. wish to participate in the establishment and operation of the Project Demonstrating Energy Conservation Applications to Building Complexes as provided in this Agreement (the "Project");

ConstDering that the Contracting Parties which are governments. and the governments of the other Contracting Parties (referred to collectively as the "Governments") participate in the International Energy Ayency (the ".. Agency") and have agreed in Article 41 of the Agreement on an Intemational Energy Program (the "I.E.P. Agreement") to undertake national programmes and to promote the adoption of cooperative programmes in the areas set out in Article 42 of the I.E.P. Agreement, including the area of energy research and development in energy conservation;

Considering that in the Governing Board of the Agency on 28th July, 1975 the Governments approved the Project as a special activity under Article 65 of the I.E.P. Agreement;

CONSIDERING that the Agency has recognized the establishment of the Project as an important component of international co-operation in the field of energy conservation:

HAVE AGREED as follows:

Article I

\section{OBJECTIVES}

Background-The Ministry for Research and Technology of the Federal Republic of Germany ("the Ministry") is currently funding the operation of two energy conservation demonstrations and rest installations. The scope of work tor these two programmes consists of the following: 
(a) Esslingen Programme-Located in the City of Esslingen (FRG). This programme involves the provision of all space heating and domestic hot water requirements for a complex of three high-rise apartment buildings by a central water to water heat pump system which extracts heat from river water. The building complex also has an alternate oil-fired heating system which can provide the full heating requirements. The primary experiment will be a three to tive-year programme of heat pump system performance evaluation and comparison with oil-tired heating. Evaluation of the energy effects $0:$ different end-use heat delivery systems (lloor heating vs. radiator heating) and the effects of two different levels of exterior wall insulation will also be conducted.

(b) Wiehl Large-Scale Experimental Plant Programme-This complex consists of a multi-purpose community recreational facility whose energy system teatures many subsystems such as waste heat utilization. heat recovery from waste water and ventilation exhaust, waste water utilization. heat loss reduction, solar energy collection and heat pumps. These multiple subsystems are integrated by design for operation as a synergistically optimized energy system tor important tests and evaluations in the rational use of energy. A programme of operating tests. analyses and technological studies and evaluations will be developed to cover a period of from five to ten years.

It is the objective of the Contracting Parties to design and implement the Project, which shall consist of the following elements:

(1)

The programme of work associated with the design and implementation of the experimental activities at the Wiehl and Esslingen fiacilities, which is intended to be specifically described at Annex I to this Agreement (hereinatter reterred to as "the Programme"), including

(i) exchange of cechnical personnel for conduct of experiments at the Esslingen and Wiehl tacilities. and elsewhere as agreed by the Joint Working Party;

(ii) sharing of intormation developed and acyuired by the Contracting Parties as a result of the design and implementation of the atoresaid experimental activities; and

(iii) designn. execution and evaluation of agreed upon experiments ussociated with the aforesaid experimental attivities: and

(2)

Design. execution and evaluation of additional agreed upon joints experiments (beyond those contemplated in Annex l) associated with the facilities at Esslingen. Wienl and elsewhere.

Article ?

OPERATING AGENT

(a) The Project shall be operated by an Operating Agent. The functions of the Operating Agent shall be pertormed by Energietechnik GmbH Studiengesellschatt tür 
Energieumwandlung-Fortleitung und-Anwendung ("ETS"), which is also a Contracting Party, acting under a contract with the Ministry.

(b) The Operating Agent shall develop and deliver to the other Contracting Parties periodic reports. us listed in Annex II. on the ongoing evaluations of systems pertormance resulting trom execution of the Programme described in Annex I: together with reports, as determined by the Joint Working Party. on the conduct of additional agreed upon joint experiments.

(c) All legal acts required to operate the Project shall be performed on behalf and tor the account of the Contracting Parties by the Operating Agent. Subject to the provisions of Article 7 . the Operating Agent shall. for the benefit of the Contracting Parties. be the sole legal owner of all property rights which may be acquired for the Project or which shall accrue to the Project in currying out its objectives. The Operating Agrent shall operate the Project under its supervision und responsibility. subject to this Agreement. in accordance with the law of the Federal Republic of Germany.

(d). The Operating Agent shall be responsible for taking all steps required to implement the Project in accordance with this Agreement. and with decisions of the Joint Working Party. Such responsibility shall include. but not be limited to:

(1) In accordance with the decisions of the Joint Working Party. executing the Programme. and additional agreed upon experiments:

(2) Acquiring on behalf of the Contracting Parties information and data; and. subject to the provisions of Article 7 , intellectual property rights now held by third parties (or which cannot be used without the consent of third parties) which are necessary for the purposes of carrying out the Project and exploitation of the results thereot; in so doing, the Operating Agent shall not enter into any commitment not authorized by the Joint Working Party;

(3) Operating the test equipment and such instrumentation which may be installed in accordance with the Programme and additional agreed upon joint experiments, and letting all contracts necessary in connection therewith in accordance with the rules laid down pursuant to this Agreement:

(4) Recording the results of the operation of the experiments in iccurdance with a procedure approved by the Joint Working Party;

(5) Performing such analysis of the results as is agreed by the Joint Working Party.

Article 3

JOINT WORKING PARTY OF EXPERTS

(a) Control of the Project shall be vested in the Joint Working Party of Experts (the "Joint Working Party") constituted under this Article and decisions reached by the 
Joint Working Party under the provisions of this Article shall be binding on the Operating Agent and each Contracting Party.

(b)

The Joint Working Party shall consist of one representative designated by each of the Contracting Parties. Each member of the Joint Working Party may appoint technical or other advisers. Each Contracting Party shall inform the other Contracting Parties in writing of all designations under this paragraph.

(c) As of the date of execution of this Agreement. the Parties have not yet agreed upon the Programme which is intended to be included as Annex I hereto. Accordingly. within 60 days after entry into torce of this Agreement. the Joint Working Party shall agree upon:

(1) A definitive five-year overall scope of work on the Programme covering methodologies. instrumentation and data acquisition schemes. and the experiment design and operation schedule; and

(2) A detailed work management plan covering the first twelve-month period of work of the Programme. including identification of specific tasks and subtasks. manpower and cost allocation tor each task and subrask. and detailed time schedule for performance of the tasks.

In the event the Joint Working Party tails to agree upon Annex I within such 60-day period. this Agreement shall be deemed to be terminated. without turther obligation to the Parties.

(d). The Parties intend that the detailed work management plan as described above for each twelve-month period subsequent to the first. twelve-month period covered by this Agreement will be considered by the Joint Working Party sutficiently in advance of its being carried out so as to allow the Joint Working Party to consult thereon and make recommendations with respect thereto. Accordingly. betore ETS adopts each such subsequent tweive-month work management plans. ETS shall submit it to the Joint Working Party, and shall exercise its best efforts to ensure that recommendations of the other Contracting Parties are incorporated therein. The purpose of the toresoing procedure is to ensure that each such twelve-month work management plan will make the maximum contribution to each Party's national programmes.

(e) The Joint Working Party mav also dyree upon additional joint experiments to be made part of the Project. Such additional joint experiments. which may be pertormed at the facilities of Wiehl, Esslingen or elsewhere. shall be conducted in accordance with decisions of the Joint Working Party and with the applicable provisions of this Agreement.

$(f)$ The Joint Working Party shall evaluate Project results. including results of specific experiments to be carried out.

(g) Members of the Joint Party of Experts shall be remunerated by their respective employers and shall be subject to their employers' conditions of service.

(h) The Joint Working Party shall adopt the Project Budget and shall make such rules and regulations as may be required tor the sound management of the Project, including tinancial rules as provided in Article 5. 
(i) Each member of the Joint Working Party shall have one vote, and all decisions shall be by unanimity.

(i) The Joint Working Party shall meet in regular session at least once each year to evaluate detailed work management plans; each Contracting Party shall have the right to call additional such sessions by giving notice to the ocher Contracting Parties. Meetings of the Joint Working Party shall be held at such locations as may be mutually agreed upon.

(k)

At least 28 days betore each meeting of the Joint Working Party, the Operating Agent shall give notice of the time. place and purpose of the meeting to the other Contracting Parties and to other persons or entities entitled to attend. All members of the Joint Working Party shall be present to produce a quorum for the transaction of business in meetings of the Joint Working Party.

(l) The Joint Working Party shall provide the Agency with periodic reports on the Project.

Article 4

ADMINISTRATION AND STAFF

(a) The Operating Agent shall have sole responsibility for the administration and provision of staff for this Project; remuneration of the staff of the Project shall be the sole responsibibility of the Operating Agent.

(b) Each Contracting Party may schedule visits by its personnel to the Esslingen and Wiehl facilities (and any other locations where Project activities are conducted) during the period of this Agreement to familiarize themselves with the Esslingen and Wiehl Building Complexes and to monitor the operation of the Project. Each such visit shall be notified in advance to the Operating Agent. The Contracting Party whose personnel make such visits shall bear all costs of such visits.

Article 5

FINANCE

(a) The Ministry represents that it has expended more than 12.5 million DMl to construct the Wiehl Large-Scale Experimental Plant and to provide the large heat pump installation at the Esslingen project. Additionally, under the experimental prosramme planned by the Ministry, approximately 1 million DM will be expended tor instrumentation and data acquisition systems and an additional 1 million DM per year will be expended for salaries of project technical personnel and test set up and modification work. In consideration of these investments by the German side. the total funding support partici- 
pation of the United States Energy Research and Development Administration (the "U.S. ERDA") for the duration of the Programme shall consist of an overall cash contribution of $\$ 240,000$. The contribution of each Contracting Party to any additional joint experiments, which shall be tunded in common. shall be agreed by the Joint Working Party.

(b)

The aforementioned cash contribution of U.S. ERDA shall be made in U.S. dollars. and shall be due and payable within 90 days after the date on which the Joint Working Party, pursuant to Article $3(c)$, adopts Annex I hereto. The contribution shall be paid to ETS. Such contribution shall be carried on the books of the Operating Agent as part of the Project Budget, shall be solely for use in the Programme. and shall be used by the Operating Agent tor no other purpose.

(c) Subject to the Project Budget and to the overall direction of the Joint Working Party. budget planning and financial management of the Project shall be the responsibility ot the Operating Agent. Notwithstanding the toregoing

(1) The Operating Agent shall. in maintaining books and records covering operation of the Project. employ a system of accounts in accordance with accounting principles generally accepted in the Federal Republic of Germany;

(2) The Operating Agent shall maintain complete, separate tinancial records which shall clearly account tor all tunds and property coming into the custody or possession of the Operating Agent in connection with the Project. All such records shall be maintained for at least three years from the date of termination of the Project:

(3) Each Contracting Party shall have the right. at its sole cost and discretion, to audit the accounts of the Project to assure that its contribution thereto has been utilized in accordance with this Agreement. No Contracting Party shall be entitled to conduct more thun one such uudit in any calendar year;

(4) The Operating Agent shall pay all taxes and similar impositions imposed by national or local governments and incurred by it in connection with the Project.

(d) Each Contracting Party shall bear all costs of its participation in the Project other than the common costs funded by the Project Budget.

Article 6

PROCUREMENT PROCEDURES

(a) The Operating Agent shall have power to enter into agreements for the appointment of consultants. construction of plant and procurement of materials in the 
interest of the Project provided that such agreements are allowed for in the Project Budget and by the provisions of this Agreement.

(b) The Operating Agent shall procure quotations and tenders, and let and administer all agreements for the construction of plant or procurement of materials in accordance with the Ministry's document "BewGr - DMBW", issued on 1st September, 1972.

\section{Article 7}

\section{INFORMATION AND INTELLECTUAL PROPERTY}

(a) The publication, distribution, handling, protection and ownership of information and intellectual property arising trom the additional joint experiments shall be determined by the Joint Working Party in conformity with this Agreement.

(b) Subject only to restriction applying to patents and copyrights, the Contracting Parties shall have the right to publish all information provided to or arising from additional joint experiments except proprietary intormation. Proprietary information shall not be accepted for or utilized in additional joint experiments without express approval of the Joint Working Party, except for proprietary information associated with the Esslingen and Wiehl Programmes.

For the purposes of this Article. proprietary information shall mean intormation of a confidential narure such as trade secrets and know-how (for example, computer programmes, design procedures and techniques, chemical composition of materials, or manufacturing methods, processes, or treatments) which is appropriately marked. provided such information:

(1) Is not generally known or publicly available from other sources;

(2) Has not previously been made available by the owner to others without obligation concerning its confidentiality; or

(3) Is not already in the possession of the recipient Contracting Parties without obligation concerning its confidentiality.

The Operating Agent and the Contracting. Parties shall take all necessary measures in accordance with this Article. the laws of their respective countries and international law to protect proprietary information.

(c) The Operating Agent shall provide the reports listed in Annex II and reports of all work performed and information developed under additional joint experiments without restriction to each Contracting Party. Each Contracting Party shall be entitled to the following additional information:

(1) Information related to the Esslingen and Wiehl Programmes which has not been held confidential by ETS and the FRG, without restriction; and 
(2) Proprietary information related to the Esslingen and Wiehl Programmes for use only in relation to each Contracting Party's research and development programmes.

(d) ETS shall license proprietary information related to the Esslingen and Wiehl Programmes and which has been utilized in the Project:

(1) Royalty-tree to the Government of each Contracting Party for governmental use in its country only; and

(2) On reasonable terms and conditions to the Contracting Parties, their Governments and nationals of their countries designated by the Contracting Parties for use in all countries.

(e) Each Contracting Party agrees to license, on reasonable terms and conditions. all patents owned or controlled by it which are useful in practising the results of the Project and have been utilized in the Project, to the Contracting Parties, their Governments and the nationals of their countries designated by the Contracting Parties for use in all countries.

(f) Patents owned or controlled, in whole or in part. by parties other than Contracting Parties may be procured by or licensed to the Operating Agent tor use in additional joint experiments only with express approval of and under terms and conditions stipulated by the Joint Working Party.

(g) Inventions made or conceived in the course of or under the Project (arising inventions) shall be identified promptly and reported by the Operating Agent along with a recommendation of the countries in which patent applications should be filed. The Joint Working Party shall establish procedures for processing such recommendations to determine where and when patent applications will be filed at the expense of the Project.

Information regarding inventions on which patent protection is to be obtained shall not be published or publicly disclosed by the Operating Agent or the Contracting Parties until a patent application has been filed in any of the countries of the Contracting Parties. provided. however. that this restriction on publication or disclosure shall nor extend beyond six months from the date of reporting of the invention. It shall be the responsibility of the Operating Agent to appropriately mark Project reports which disclose inventions that have not been appropriately protected by the filing of a patent application.

(h) Except as otherwise agreed upon by the Contracting Parties for additional joint experiments, patents obtained on inventions arising trom the Project shall be owned by:

(1). Each Contracting Party in its own country, subject to a nonexclusive. irrevocable, royalty-free licence to the other Contracting Parties and their Governments, and on reasonable terms and conditions to the nationals of their countries designated by the Contracting Party; and

(2) ETS in all other countries, subject to a nonexclusive, irrevocable, royaltyfree licence to the other Contracting Parties and their Governments, and 
on reasonable terms and conditions to the nationals of their countries designated by the Contracting Party.

(i) The Operating Agent shall take appropriate measures necessary to protect copyrightable material generated under the Project. Copyrights obtained shall be the property of the Operating Agent for the benefit of the Contracting. Parties, provided. however, that the Contracting Parties may reproduce and distribute such material, but shall not publish it with a view to profit.

(j) Each Contracting Party and the Operating Agent will, without prejudice to any rights of inventors or authors under its national laws, take all necessary steps to provide the co-operation from its authors and inventors required to carry out the provisions of this Article. Each Contracting Party will assume the responsibility to pay awards or compensation required to be paid to its employees according to the laws of its country.

(k) The Joint Working Party may establish guidelines to determine what constitutes a "national" of a Contracting Party. Disputes that cannot be settled by the Joint Working Party shall be settled under Article 9 (d).

\section{Article 8}

\section{LEGAL RESPONSIBILITY AND INSURANCE}

(a) The Operating Agent shall ise all reasonable skill and care in carrying out its duties under this Agreement and shall be responsible for ensuring that the Project is conducted in accordance with all relevant laws and regulations. Except as otherwise provided in this Article, the cost of all damage to property and all legal liabilities. claims. actions, costs and expenses connected therewith, shall be borne by the Project Budget.

(b)

The Operating Agent shall carry such liability, fre and other insurance as the Joint. Working Party may direct. The cost of obtaining and maintaining insurance shall be charged to the Project Budget.

(c) The Operating Agent shall be liable in its capacity of Operating Agent to indemnify the Contracting Parties against the cost of any dimage to property and against all legal liabilities, actions, claims, costs and expenses connected therewith to the extent that they:

(1) Result from the failure of the Operating Agent to maintain any such insurance as it is required to maintain under paragraph $(b)$ above; or

(2) Result from the gross negligence or wilful misconduct of any of the Operating Agent's employees or otficers carrying out its duties under this Agreement.

(d) The obligations of each of the Contracting Parties (other than iny obligations to make payment of any monies as hereinbefore provided) shall be suspended tor any 
period during which such Contracting Party is prevented or substantially hindered from complying therewith in whole or part by any cause beyond its control including, but not limited to, acts of God, unavoidable accidents, laws, rules. regulations or orders or any national, state, governmental or local authority, acts of war or conditions arising out of or attributable to war, strikes. lockouts or other disputes with workpeople. shortages of materials, equipment or labour or shortages of or delays in transportation; the Contracting Party so prevented or hindered shall give notice to the other Contracting Parties promptly after the start and finish of such prevention or hindrance.

\section{Article 9}

\section{LEGISLATIVE PROVISIONS}

(a) Each Contracting Party shall, within the framework of the applicable, existing legislation, use its best endeavours to facilitate the accomplishment of formalities involved in the movement of persons, the importation of materials and equipment and the transfer of currency which shall be required to operate the Project.

(b) The participation of each Contracting Party in the Project shall be subject to the appropriation of funds by the appropriate governmental authority and to the laws and regulations applicable to the Contracting Party, including but not limited to. laws establishing prohibitions upon the payment of commissions. percentages. brokerage or contingent fees to persons retained to solicit government contracts, and upon any share of such contracts accruing to governmental officials.

(c) The Project shall in.its operations take account of the Guiding Principles for Co-operation in the Field of Energy Research and Development adopted by the Governing Board of the Agency, and any modification thereto as well as other decisions of the Governing Board in that tield. The termination or modification of those Guiding Principles shall not affect this Agreement and this Agreement shall continue in torce in accordance with its terms.

(d) Prior to submitting any dispute to a court of competent jurisdiction. the Contracting Parties shall attempt to settle such dispute by negotiation or other agreed mode of settlement. It is anticipated that any law proceedings will normally take place at Essen, Federal Republic of Germany; however, nothing shall preclude a Contracting Party from submitting any dispute to any court of competent jurisdiction.

(e) Any Contracting Party may request permission to provide specialized equipment or materials for testing in the facilities at Wiehl and Esslingen. Such requests shall be made to the Joint Working Party which shall establish the terms and conditions (including charges) to be applicable to such tests. Any charges received as a result of such tests shall be credited to the Project Budget. 
Article 10

\section{ADDITION AND WITHDRAWAL OF CONTRACTING PARTIES}

(a) Participatiun in the Project as a Contracting Party shall be open at all times to the government of any Agency Participating Country (or a national agency, public organisation, private corporation. company or other entity designated by such government) which requests participation in the Project, signs this Agreement and assumes the rights and obligations of a Contracting Party. Such participation shall be effective upon the adoption of consequential amendments to this Agreement.

(b) The governments of other Members of the Organisation for Economic Cooperation and Development may. on the proposal of the Joint Working Party, be invited by the Governing Board of the Agency to participate in the Project by signing this Agreement, and to assume the rights and obligations of a Contracting Party (or to designate a national agency, public corporation. private corporation, company or other entity to do so). Such participation shall be effective upon the adoption of consequential amendments to this Agreement.

(c) The European Communities may take part in the Project in accordance with arrangements to be made with the Joint Working Party. Such participation shall be effective upon the adoption of consequential amendments of this Agreement.

(d) It shall be a condition of admission of any new Contracting Party under Articles $10(a)$ or $10(b)$ above or participation under Article $10(c)$ above that the Contracting Party shall contribute in accordance with rules laid down by the Joint Working Party, an appropriate proportion of the expenditure of the Project prior to the date of. such admission.

(e) Any Contracting Party may withdraw from this Agreement at any time with the agreement of the Joint Working Party. The withdrawal of any Party shall not affect the rights and obligations of the Contracting Parties under Article 7. A withdrawing Contracting Party shall notify the Agency of its withdrawal.

Article II

REDUCTION OF PROGRAMME

In the event that the Programme described in Annex I for the entire five-yedr period (or any part thereol) is substantially reduced in scope by the ETS (or at the direction of the Ministry), the Contracting Parties shall negotiate with a view to determining whether the cash contribution made by the U.S. ERDA hereunder should be retunded in whole or in part, in accordance with the principle that the aforesaid cash contribution represents an expectation on the part of the U.S. ERDA that the full Programme as contemplated in Annex I shall be performed. 


\section{FINAL PROVISIONS}

(a) This Agreement shall remain in torce tor an initial period of five years trom the date hereof and shall continue in force thereafter if the Contracting Parties so decide. If the Contracting Parties enter into a comprehensive Implementing Agreement covering a number of tasks in the field of energy conservation research and development. they will endeavour to include the present Project in such Implementing Agreement.

(b)

The Operating Agent may in addition to the provisions laid down in Article $2(c)$ and $6(a)$ enter into agreements in the interest of the Project in accordance ivith rules laid down by the Joint Working Party. Such agreements may provide for exchanges of intormation, scientific and technical personnel, associated with the work of the Project and other matters agreed by the Joint Working Party.

(c) Nothing in this Agreement shall be regarded as constituting a partnership between the Contracting Parties or any of them.

(d) Any notice or information required to be served or given to a Contracting Party under this Agreement shall be addressed to the designated representative of the Contracting Party nominated to the Joint Working Party and if sent by first class telex or cable shall be deemed to be duly given 24 hours after being dispatched.

(e) Subject to the provisions of Article 7, all assets of the Project shall, except as contemplated in Article 9 (e), be owned by the Operating Agent and shall be retained by the Operating Agent upon termination of this Agreement.

(f) This Agreement may be amended at any time by the Contracting Parties. Such amendments shall come into force in a manner determined by the Contracting Parties.

(g) The original of this Agreement shall be deposited with the Executive Director of the Agency and a certified copy thereot shall be turnished to each Contracting Party. A copy of this Agreement shall be furnished to each Agency Participating Country, to each Member country of the Organisation for Economic Co-operation and Development and to the European Communities.

Done in Bonn, this 28th day of June, 1976 : 
For the ENERGIETECHNIK GMBH STUDIENGESELLSCHAFT FÜR

ENERGIEUMWANDLUNG-

FortLEITUNG UND-ANWENDUNG

(proposed by the Federal Republic of Germany):
MEYSENBURG

STOY

FOR THE ENERGY RESEARCH AND

Frank E. CASh, JR. DEVELOPMENT ADMINISTRATION

for and on behalf of the Government of the United States of America: 


\section{ANNEX [}

TO BE INSERTED HERE WHEN AGREED BETWEEN THE CONTRACTING PARTIES, AS PROVIDED IN ARTICLE $3(C)$. 


\begin{abstract}
ANNEX II
The following deliverables should be supplied to the Contracting Parties by the Operating Agent:

(a) Wieht Large-Scale Experimental Plant

(1) Preliminary report of winter operating season-due in January of each year;

(2) Full report of winter operating season-Jue in May of each year;

(3) Preliminary report of summer operating season-due in July of each year;

(4) Full report of summer operating season-due in October of each year.

(b) Esstingen Project

(1) Semi-annual report of evaluation of Joint Project operations for the periods of Ist July through 3 lst December-due in January of each year.

(2) Semi-annual report of evaluation of Joint Project operations for the periods of lst January through 30 th June, and of Ist July through 30 th June-due in July of each year.
\end{abstract}


The Legal Advisor of the International Energy Agency hereby certifies that the present copy conforms to the original text deposited with the Executive Director of the International Energy Agency.

Paris,

THE LEgal AdVISOR:

RICHARD F. SCOTT 
INTERNATIONAL ENERGY AGENCY

IMPLEMENTING AGREEMENT FOR A PROGRAMME OF RESEARCH AND DEVELOPMENT ON ENERGY CONSERVATION THROUGH ENERGY CASCADING 
THIS PAGE

\section{WAS INTENTIONALLY LEFT BLANK}




\section{IMPLEMENTING AGREEMENT FOR A PROGRAMME OF RESEARCH AND DEVELOPMENT ON ENERGY CONSERVATION THROUGH ENERGY CASCADING}

Aricle 1

OBjectives

Article ?

IDENTIFICATION ANO INITIATION OI TASKS

Iricile i

The Executive Committel

Aricle +

The Operiting hgents

- rricle 5

sricle 6 
Arricle 7

INFORMation and INTEll.ectual Property

Article 8

LEGAL RESPONSIBILITY ANO INSURANCE

Article 9

Legislative Provisions

Article 10

admission and Withorawal. of Contracting Partifs

Aricle 11

Final Provisions

ANIVEX I

Common Study on Energy Cisciding;: Estabilisiling Priorities

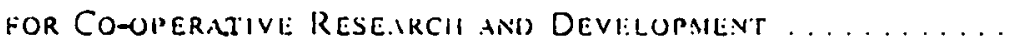




\title{
IMPLEMENTING AGREEMENT FOR A PROGRAMME OF RESEARCH AND DEVELOPMENT ON ENERGY CONSERVATION THROUGH ENERGY CASCADING
}

\author{
The Contracting Parties
}

Considerivg that the Contracting Parties: being either governments or international organisations or parties designated by their respective governments pursuant to Article III of the Guiding Principles for Co-operation in the Field of Energy Rosearch and Development adopted by the Governing Board of the International Energy Agency (the "Agency") on 28ch July. 1975. wish to take part in the establishmene and operation of a Programme of Rescarch and Develupment on Encrgy Conservation through Energy Cascading (the "Programme") as provided in this Agrcentent:

CONSIDERING that the Contracting Parties which are governments and the governments of the other Contracting Parties (rcterred to collectivaly as the "Governnicnts") participate in the Agency and have agreed in Article $+l$ of the Agrecment on an Intcr. national Energy Program (the "I.E.P. Agreement") to undertake national programmes in the areas set out in Article 42 of the l.E.P. Agrcement. including research and devel. opment on energy conservation in which lield the Programme will be carricd out:

Consideriag that in the Governing Board of the Agency on 16th Warch. 1977 the Governments approved the Programme as a special activity under Article 65 of the I.E.P. Agreement;

CONSIDERING; that the Agency has recognised the sstablishment of the Programme as an important component of international co-nperation in the field of energy conservation research and development:

HAVE AGREED as follows:

Article 1

OBJECTIVES

(a) Scope of detivity. The Programme to bic carried out by the Contracting: Parties within the framework of this Agreenent shall consise of co-nperative rescarch. devclopment. demonstrations and exchanges of infurmation regurding encrgy conscrvation through energy casciding. 
Programme by undertaking one or more tasks (the "Task" or "Tasks") each of which will be upen to participation by two or more Contracting Parties as provided in Article 2 hereot. The Cuntracting Parties. which participate in a particular Task are, for the purposes of that Task, refiored to in this Agreement is "Purticipants".

(c) Task Co-ordination and Co-operation. The Contracting Parties shall cooperate in co-ordinating the work of the various $T$ atsks and shall endeavour. on the basis of an appropriate sharing or burdens and benctics. to encourage co-operation among Participants engaged in the various Tasts with the objective of alvancing the research and development activities of all Contracting Parties in the tield of ener@y cunservation through energy cascading.

\section{Article?}

\section{IDENTIFICATION AIVD INITIATION OF TASKS}

(a) Identification. The Tasks undertaken by Participants are idencitied in the Annexes to this Agreement. At the time of signing this Agreement, eath Contracting Party shall confirm its intention to participate in une or more $T$ asks by giving the Exccutive Director of the Agency a Notice of Participation in the relevant Annex or Annexes and the Operating Agent for each Task shall give the Executive Director of the Agency a Notice of Acceptance of the Task Annex. Therealiter, edch Task shall be curried out in accordance with the procedures set forth in Articles 2 to 11 hereof. unless otherwisc specifically provided in the applicable Annex.

(b) Initiation of Addirional Tasks. Additional Tast's maly be initialed by any Contracting Party according to the following procedure:

(1) A Contracting Party wishing to initiate a new Task shall present to one or more Contracting Parties tor approval at uratt Annex. similar in form to the Annexes attached hereto. containing it description of the scope of work and condicions of the Task proposid (n) be pertormed:

(2) Whenever two or more Contracting Pirties ugree to undertake a new Task. they shall submit the Urait Annex ror approval by the Executive Committee pursuant to Article 3(e) (2) hereot: the spproved dratt Annex shall beconle part of this Agrcencent: Vutice of Participation in the Tast by Contracting Partics and acospance by the Operating tgent shall be communicaled to the Exccutive Directore in the manner provided in paragraph (a) above:

(3) In carrying out the various Tasks. Participants shall co-ordinate their activities in order to arvoid duplication of ativities.

(c) Application of Tast Amexes. Eald Annex shall be binding only upon the Participants therein and upon the Operating. Agent. for that Tast. and shall not allect the rights or obligations of other Contracting Parties. 
Article 3

\section{THE EXECUTIVE COMMITTEE}

(a) Supervisory Control. Control of the Programme shall be vested in the Executive Committee constituted under this Article.

(b) Memhership. The Executive Committes shall consist of one nember designated by each Contracting Party; each Contracting Party shall also designate an altcrnute member to serve on the Executive Committee in the event that its designated member is unable to do so.

(c) Responsithilitics. The Exccutive Committee shall:

(1) Adopt for each year, acting by unanimity, the Programme of Work. and Budget if foreseen. for each Task. logether with an indicative programme of work and budget for the following two years: the Executive Conmittee may, as required, make adjustments within the framework of the Programme of Work and Budget:

(2) Make such rules and regulations as may be required for the sound management of the Tasks. including financial rules as provided in Article 6 hereof;

(3) Carry out the other functions conferred upon it by this dgreement and the Annexes herero:" and

(4) Consider any matters submitted to it by any of the Operating Agents or by any Contracting Party.

(d) Precedure. The Executive Committes shall carry out its responsibilitics in accordance with the lollowing procedures:

(1) The Executive Committee shall each year elect a Chaiman and nne or more Vice-Chairmen:

(2) The Executive Committee may establish such subsidiary bodics and rules of procedure as are required for its proper functioning. A representitive of the Agency and a representative of each Operating Agent (in its capacity as such) may attend meetings of the Executive Conmittee and its subsidiary bodies in an idvisory capacity:

(3) The Executive Committee shall meer in regthlar session twice cich vear: a special meeting shall be convenced upon the reyuest of any Contracting Party which can demonstrate the need herefor:

(4) Meetings of the Executive Committes shall be held at such time and in such office or offices as may be designated by the Comimiltee; 
(5) At least twenty-eight days before each meeting of the Executive Committee, notice of the time. place and purpose of the meeting shall be given to each Contracting Party and to other persons or entities entitled to attend the meeting; notice need not be given to any person or entity otherwise entitled thereto if notice is waived before or after the meeting;

(6) The quorum for the transaction of business in meetings of the Executive Committee shall be one-half of the members plus one (less any resulting. fraction) provided that any action retating to a particular Tush shall require a quorum as aioresaid of members or alternate members designated by the Participants in that Task.

\section{Voting.}

(1) When the Executive Committee adopts a decision or recommendation for or concerning a particular Task. the Executive Committee shall act:

(i) When unaninity is required under this Agreement: by agrcement of those members or alternate members which were designated by the Participants in that Tusk and which are present and voting:

(ii) When no express voting provision is made in this Agreement: by majority yoce of those members or alternate members which were designated by the Participants in that Task and which are present and voting;

(2) In all other cases in which this Agreement expressly requires the Executive Committec to act by unanimity. this shall require the agreement of each member or alternite nember present and voting, and in respect of ail other decisions and recommendations for which no express voting provision is malde in this Agrement. the Exccutive Committe shall act by a majority vote of the members or alternate members present and voting. If a governmene has designated more than one Coneracting Party to this Agreement. those Contracting Partics may cast only one vote under this pardyraph:

(3) The decisions and recommendations referred to in paragraphs (1) and (2) above may, with the agreement of each member or alternate member entitled to act thereon, be made by mail, telex or cable without the necessity for calling a meeting. Such action shall be taken by unanimicy or majority of such members as in at meeting. The Chairman of the Executive Committee shall ensure that all inembers are intormed of each decision or recommendation miade pursuant (1) this paragraph.

(f). Reports. The Executive Committe shall. at least annually, provide the Agency with periodic reports on the progress of the Programme. 


\section{Article 4}

\section{THE OPERATING AGENTS}

(a) Designation. Participants shall designate in the rclevant Annex an Operating Agent for each Task. References in this Agreement to the Operating Agent shall apply to each Uperating Agent in respect of the lask for which it is responsible.

(b) Scope of Authority to Act on Behalf of Participants. Subject to the provisions of the applicable Annex:

(1) All legal acts required to carry out each Task shall be performed on behalf of the Participants by the Operating Agent for the Task:

(2) The Operating Agent shall hold. for the benefit of the Participants. the legal title to all property rights which may accrue to or be acquired for the Tusk.

The Operating Agent shill operate the Tas' under its supervision and responsibility. subject to this Agreement. in accordance with the law of the country of the Operating Agent.

(c) Reimhursements of Couss. The Excoutive Committec maly provide that expenses and costs incurred by an Operating Agent in acting as such pursuant to this Agreement shall be reimbursed to the Operating Agent from funds made available by the Participants pursuant to Article 6 hereof.

(d) Replacement. Should the Executive Committee wish to replace in Operating Agent with another government or entity. the Exccutive Committec may. acting by unanimity and with the consent of such gnvernment of entity. replace the initial Operateng Agent. References in this Agreement to the "Operating Agent" shall inctude any government or entity appointed to replace the original Operating Agent under this paragraph.

(e) Resignetrion. An Optating Agent shall have the right to resign alt any time, by giving six months written notice to that elfoct to the Exccutive Comnittes. provided that:

(1) A Participant. or cntity designated by a Participant. is at such time willing to assume the duties and obligations of the Operating Agent and so notifics the Executive Committec and the other Participants to that effect, in writing. not less than thres montls in advance of the effective date of such resignation; and

(2) Such Participant or entity is approved by the Executive Committee. acting by unanimity.

(f) Accounring. An Opcrating regent which is replaced or which resigns as Operating Agent shall provide the Exccutive Committe with an accounting of any monies and other assets which it may have collected or acquired for the Task in the course of carrying out its responsibilities as Operating Agent. 
(g) Transfer of Rights. In the event that another Operating Agent is appointed under paragraph (d) or (e) above, the Operating Agent shall transfer to such replacement Operating Agent any property rights which it may hold on behalf or the Task.

\section{Article $S$}

\section{ADMINISTRATION AND STAFF}

(a) Administration of Tasks. Each Operating Agent shall be responsible to the Executive Committee for implementing its designated Task in accordance with this Agreement, the applicable Task Annex, and the decisions of the Executive Committee.

(b) Information and Reports. Each Operating Agent shall furnish to the Executive Committee such information concerning the Task as the Committee may request and shall each year submit, noc later than two months alter the end of the financial year. a report on the status of the Task.

(c) Staff. It shall be the responsibility of the Operating Agent to retain such staff as may be required to carry out its designated Tusk in accordance with rules determined by the Executive Committee. The Operating Agent may also, as required. utilise the services of personnel employed by other Participants (or organisations or other entities designated by Contracting Parties) and made available to the Operating Agent by second. ment or otherwise. Such personnel shall be remunerated by their respective employers and shall, except as provided in this Article, be subject to their employers' conditions of service. The Contracting Parties shall be entitled to claim the appropriate cost of such remuneration or to receive an appropriate credit for such cost as part of the Budget of the Task, in accordance with Article $6(f)(6)$ hereot.

\section{Article 6}

\section{FINANCE}

(a) Individual Obligations. Each Contracting Party shall bear the costs it incurs in carrying out this Agreement, including the costs of formulating or transmitting reports and of reimbursing its employees for travel and orher per liem expenses incurred in connection with work carried out on the respective Tasks. unless provision is made for such costs to be reimbursed from common funds as provided in paragraph ( $g$ ) below.

(b) Common Financial Obligations. Participants wishing to share the costs of a particular Task shall agree in the appropriate Task Annex to do so. The apportionment of contributions to such costs (whether in the form of cish. services rendered, intellectual property or the supply of materials) and the use of such contributions shall be governed by the regulations and decisions made pursuant to this Article by the Executive Committee. 
(c)

Rules of Procurement. Expenditure. The Executive Committee. acting by unanimity, may make such regulations as are required for the sound financial management of each Task including, where necessary:

(1) Establishment of budgetary and procurement procedures to be used by the Operating Agent in making payments from any common funds which may be maintained by Participants for the account of the Task or in making contracts on behalf of the Participants:

(2) Establishment of minimum levels of expenditure for which Executive Committee approval shall be required, including expenditure involving payment of monies to the Operating Agent for other than routine salary and administrative expenses previously approved by the Executive Committee in the budget process.

In the expenditure of common funds. the Operating tgent shall take into account the necessity of ensuring a fair distribution of such expenditure in the Participants countries. where this is Eutly compatible with the most efficient technical and rinancial management of the Task.

(d) Crediting of Income to Budget. Any income which accrues irom a Task shall be credited to the Budget of that Task.

(e) Accomming. The system of accounts employed by the Operating Agcnt shall be in accordance with accounting principles generally accepted in the country of the Operating Agent and consistently applied.

(f)

Programme of Work and Budger. Keeping of Acerumes. Should Participants agree to maintain common funds for the payment of obligations under a Programme of Work and Budget of the Task. accounts shall be maintained as follows unless otherwise decided by the Executive Committee, acting by unanimity:

(1) The financial year of the Task shall correspond to the linancial vear of the Operating Agent;

(2) The Operating Agent shall each yeạr prepare and submit on the Execurive Committe for approval a Jralt Programme of Work and Budget. together with an indicative programmic of work and budget for the following two years. noc later than three months betore the beginning of each financial year:

(3) The Operating Agrent shall matintain complete. scparate financial rccords which shall clearly account for all lunds and property coming inco the custody or possession of the Operating Agent in connection with the Task;

(4) Not later than three months atter the close of each tinancial year the Operating Agent shull submit to auditors selected by the Executive Committee for audit the annual accounts maintained tor the Task: upon completion of the annual audit, the Operating Agent shall present the 
accounts together with the auditors' report to the Executive Committee for approval;

(5) All books of account and records maintained by the Operating Agent shall be preserved for at least three years from the date of termination of the Task;

(6) Where provided in the relevant Annex, a Participant supplying. services, materials or intellectual property to the Task shill be entitled to a credit, determined by the Executive Committee, acting by unanimity, against its contribution (or to compensation, if the value of such services, materials or intellectual property exceeds the amount of the Participant's contribution); such credits for services of staff shall be calculated on an agreed scale approved by the Executive Committee and include all payroll-related costs.

(g) Contribution to Commun. Funds. Should Participants agree to establish common funds under the annual Programme of Work and Budget for a Task, any rinancial contributions due from Participants in a Tusk shall be paid to the Operating Agent in the currency of the country of the Operating Agent at such times and upon such other conditions as the Executive Committee, acting by unanimity, shall determine. provided however that:

(1) Contributions received by the Operating Agent shall be used solely in accordance with the Programme of Work anci Budget for the Task:

(2) The Operating Agent shall be under no obligation 10 carry out any work on the Task until contributions amounting to at least fifty per cent (in cash terms) of the total due at any one time have been received.

(h) Ancillary Services. Ancillary scrvices may, as agreed between the Executive Committee and the Operating Agent, be provided by that Operating Agtent tor the operacion of a Task and the costs of such services, including overhealds connected therewith. maly be met from budgeted funds of that Task.

(i) Taxes. The Operacing Agent shall pay all taxes and similar impositions (other than caxes on income) imposed by nationat or local governments and incurred by it in connection with a Task, as expenditure incurred in the operation of that Task under the Budget; the Operating Agent shall, however, endeuvour to ubtain all possible excmptions from such taxes.

(j) Audit. Each Participant shall have the right, at its sole cost. to audit the accounts of any work in a Task for which common funds are mainiained on the following terms:

(1) The Operating Agent shall provide the other Participants with an opportunity to participate in such audits on a cost-shared basis;

(2) Accounts and records relating to activities of the Operating Agent other than those conducted for the Task shall be excluded trom such audit. 
but if the Participant concerned requires verification of charges to the Budget representing services rendered to the Task by the Operating Agent, it may at its own cost request and obtain an audit certinicate in this respect from the auditors of the Operating Agent;

(3) Not more than one such audit shall be required in any financial year;

(4) Any such audit shall be carried out by not more than three representatives of the Participants.

Article 7

\section{INFORMATION AND INTELLECTUAL PROPERTY}

It is expested that for each Task agreed to pursuant to this Agreement. the applicable Annex will contain iniormation and intellectual property provisions. The General Guidelines Concerning Iniomation and Intellectual Property, approved by the Governing Board of the Agency on 21 st November, 1975, shall be taken into account in developing such. provisions.

\section{Article 8}

\section{LEGAL RESPONSIBILITY AND INSURANCE}

(a) Liability of Operating Agent. The Operating Agent shall use all reasonable skill and care in carrying out its duties under this Agreement in accordance with all applicable laws and regulations. Except as orherwise provided in this Article. the cost of all damage to property, and all expenses associated with claims, actions and ocher cosis arising from work undertaken with common tunds ior a Task shall be charged to the Budget of that Task; such costs and expenses arising trom ocher work undertaken for a Task shall be charged to the Budget of that Task if the Task Annex so provides or the Executive Committes. acting by unanimity, so decides.

(b) Insurance. The Operating Agent shall propose to the Executive Committee all necessary liability. fire and other insurance. and shall carry such insurance as the Executive Committee may direct. The cost of ootaining and maintaining insurance shall be charged to the Budget of the Task.

(c) Indemnification of Contracting Purties. The Operasing A gent shall be liable. in its capacity as such. to indemnity Participants against the cost of any damage to property and all legal liabilities. actions. claims. costs and expenses connected therewith to the extent that they: 
(1) Result from the failure of the Operating Agent to maintain such insurance as it may be required to maintain under paragraph $(h)$ above; or

(2) Result from the gross negligence or wilful misconduct of any officers or employees of the Operating Agent in carrying out their duties under this Agreement.

\section{Article 9}

\section{LEGISLATIVE PROVISIONS}

(a) Accomplishment of Formulitics. Each Participant shall, within the frame. work of applicable legislation. use its best endeavours to facilicate the accomplishment of formalities involved in the movement of persons. the importation of malterials and equipment and the transter of curroncy which shall be required to conduct the Task in which it is engaged.

(b) Applicable Laws. In carrying out this Agresment and its Annexes, the Contracting Parties shall be subject to the appropriation of funds by the apprepriate governmental authority, where necessalry. and to the constitution. laws and regulations applicable to the respective Contracting Partics, including. but not limiced (w). latvs establishing prohibitions upon the payment of commissions. percentages. brokcrage or contingent lees to persons retained to solicit governmental contracts and upon any share of such contraces accruing to governmental officials.

(c) Decisions of Agency Governing Bourd. Participants in the various Tasks shall take account, as appropriate, of the Guiding Principles for Co-operation in the Fie!d of Energy Research and Development, and any modification thereot, as well as ocher decisions of the Governing Board of the Agency in that tield. The termination of the Guiding Principles shall not affect this Agreement. which shall remain in force in accordance with the terms hereot.

(d) Settlement of Disputes. Any dispute amon@ the Contracting Partics concerning the interpretation or the application of this Agrcement which is noc scteled by negotiation or other agreed mode of settlement. shall be reterred to a tribunal of three arbitrators to be chosen by the Contracting Parties concerned who shall also choose the Chairman of the tribunal. Should the Contracting Parties concerned fail to agree upon the composition of the tribunal or the selection of its Chairman, the President of the International Court of Justice shall, at the request of any of the Contracting Parties concerned, exercise those responsibilities. The rribunal shall decide any such dispute by reference to the terms of this Agreement and any applicable laws and regulations. and its decision on a question of tact shall be linal and binding on the Contralcting Partics. Operating Agents which are not Contracting Parties shall be regurded as Contracting Parties for the purpose of this paragraph. 


\section{ADMISSION AND WITHDRAWAL OF CONTRACTING PARTIES}

(a) Admission of New Contracting Parties: Agency Countries. Upon the invitation of the Executive Committee, acting by unanimity, admission to this Agreement shall be open to the government of any Agency Participating Country for a national agency, public organisation. private corporition. company or other entity designated by such government), which signs or accedes to this Agreement, accepts the rights and obligations of a Contracting Party, and is accepted for participation in at least one Task by the Participants in that Tusk, acting by unanimity. Such admission of a Contracting Party shall become effective upon the signature of this Agreement by the new Contracting Party or its accession thereto and its giving Notice of Participation in one or more Annexes and the adoption of any consequential amendments thereto.

(b) Admission of New Contracting Parties: Other OECD Countries. The government of any Member of the Organisation for Economic Co-operation and Development which does not participate in the Agency may, on the proposal of the Executive Committee. acting by unanimity, be invited by the Governing Board of the Agency to become a Contracting Party to this Agrcement (or to designate a national agency. public organisation. private corporation, company or other entity to do so). under the conditions stated in paragraph (a) above.

(c) Participation by the European Communities. The European Communitios may participate in this Agreement in accordance with arrangements to be made by the Executive Committee, acting by unanimity.

(d) Admission of $N e w$ Participants in Tusks.s. Any Contracting Party maly. with the agreement of the Participants in a Task. acting by unanimity. become a Participant in that Task. Such participation shall become drective upon the Conerating Party's giving the Executive Director of the Agency a Notice of Participation in the appropriate Tast Annex and the aduption of conscyuential amendments thereto.

(e) Contributions. The Executive Committe may require, as a condition to admission to participation. that the new Contracting Party or new Participant shall contribute (in the form of cash. services or materials) an appropriate proportion of the prior budget expenditure of any Task in which it participates.

(f) Replacement of Contracting Parties. With the atreement of the Exccutive Committee. acting by unanimity. and upon the request of a government. a Contracting Party designated by that government may be replaced by another party. In the event of such replacement. the replacement party shall assume the rights and obligations of at Contracting Party as provided in paragraph (a) above and in accordance with the procedure provided therein.

Withdiancal. Any Contracting Party maly withdraw from this Agroument or from any Task either with the agreement of the Executive Committee. acting by unanimity. 
or by giving twelve months written Notice of Withdrawal to the Executive Director of the Agency, such Notice to be given not less than two years atter the date hereot. The withdrawal of a Contracting Party under this paragraph shall not affect the rights and obligations of the other Contracting Parties; except that. where the other Contrating Parties have contributed to common funds for a Task. their proportionalc shares in the Task Budget shall be adjusted to take account of such withdriwal.

(h) Changes of Sratus of Contracting Parcy. A Contracting Party ocher than a government or an international organisation shatl forthwith notify the Excoutive Conmittee of any significant change in its status ur ownership. wr of its becoming bankrupt or entering into liquidation. The Executive Commited shall detcrmine whether any such shange in status of a Contracting Party significantly allects the incersts of the oflace Contracting Parties: if the Executive Committee so determinus. then. unlsis the Exicutive Committes. acting upōn the unanimous decision of the ofher Contracting Partics. ocherwise argrees:

(1) That Contracting Party shall be deemed to have withdrawn from the Agrement under paragraph $(: \because)$ abous on a date 10 be tixed by the Executive Committee: and

(2) The Executive Committe shall invile the government which designated that Coneracting Party to designale. within a periogl of three monchs of the withdraval of that Contracting Party, a different encity to become a Contracting Party: if approved by the Executive Committee. acting by unanimity, such entity shall become a Contrateng Party with erfect from the date on which it signs or accedes to this Agreement and gives the Executive Director of the Ayency a Notice of Participation in one or more Annexus.

(i) Failure to Fulfil Coneracual Obligations. Any Contracting Party which fuils to fultil its obligations under this Agreoment within sixty days aller its receipt of notice specifying the nature of such failure and invoking this paragraph. maly be decmed by the Executive Committes, acting by unanimity, to have withdrawn from this Agreement.

Article 11

\section{FINAL PROVISIONS}

(a) Term of agreement. This Agreenent shall remain in force for an initial period of three years from the date hereof. and shall continue in force thereatice unless and until the Executive Committee, acting by unanimity, decides on its termination.

(b)

Legal Relationship of Contracting Partirs and Participants. Nothing in this Agreement shall be regarded as constituting a partnership becween any of the Cuntracting Parties or Participants.

(c) Termination. U'pon termination of this Agrement, or any Annex to this Agreement, the Executive Committo, actinฏ by unanimity, shall arrange for the liçuidation 
of the assets of the Task or Tasks. In the event of such liquidation. the Executive Committee shall. so far as practicable. distribute the assets of the Task. or the proceeds therefrom, in proportion to the contributions which the Participants have made from the beginning of the operation of the Task, and for that purpose shall take into account the contributions and any outstanding obligations of former Contracting Parties. Disputes with a former Contracting Party about the proportion allocated to it under this paragraph shall be settled under Article 9 (d) hercof. for which purpose a former Contracting Party shall be regarded as a Contracting Party.

(d)

Amendment: This Agreement maly be amended at any time by the Exccutive Committee. acting by unanimity, and any Anncx to this Agrecment may be anended at any time by the Executive Committe. acting by unanimity of the Participants in the Task to which the Annex refers. Such amendments shall come into force in a manner determined by the Executive Committee. acting under the voting rule applicable to the decision to adopt the amendment.

(e) Deposit. The original of this Agreement shall be deposited with the Executive - Director of the Agency and a certitied copy thereof shall be furnished to sach Contracting Party. A copy of this Agrecment shall be furnished to each Agency Participating Country. to each Member country of the Orgunisation for Economic Co-operation and Development and to the Europcan Communitics.

Done in Paris. this 16th day of March. 1977. 
For the Republic of Austria:

For the Kernforschuncsaivlage Jülich G.m.b.H. (designated by the Government of Germany):

For the National Sivedish Board for Enercy Solrce Developinent (NE)

(designated by the Government of Sweden):

For the Office Fédéral de la Scteince

ET DE LA RECHERCHE

du Départe:nent Fédéral de l'intérteur

tor and on behalf of

the Government of Switzerland:

For the Uivited States Energy Research anid Development adoministration for ind on behalf of the Government of the United States of America: 


\section{Aniex $l$ \\ COMIMON STUDY ON ENERGY CASCADING: \\ ESTABLISHING PRIORITIES FOR CO-OPERATIVE RESEARCH \\ AND DEVELOPMENT}

\section{Definition and Objective}

(a) Definition. Energy cascading is the use of presently wasted energy. usually heat. to serve end uses such as clectricity generation. process heating or space heating that would otherwise be served by primary energy suurces.

(b) Objective. The objective of this Task is to provide an overall programme plan for snhancing the chances for technical and commercial success of rescarch and development projects related to the four energy cascading topic areas:

(1) All Electric Systems:

(2) Combincd Systems:

(3) All Heat Systems:

(4) Tocal Systems.

Examples which may be of specitic intcrest for consideration are:

- The Treble Rankine Cycic Process:

- The Total Integrated Energy System:

- Recovery of Industrial Flue Gas Heac with Brayron Cycle:

- Rankine Engine to Recover Heat from a Diesol Truck Engine.

Detailed background information on the Common Study is contained in Dncument IEA/CRD(76)40, dated 14th January, 1977.

\section{Means}

A jointly-tunded Common Study ivill be undertaken whose scope of work will include the following elements:

(a) Preliminary martict research will be conducted in detemine wirere the greatest needs exist in the industrial. commercial and residential maltects:

(b) A survey of state-of-the-art technology will be made to ensure that all relevant developments will be considered: 
(c) For each technology/process that appears to tit market needs. a preliminary economic analysis will be made. These analyses will be consistently applied so as to allow eventual cost-benetit techniques to be employed tor comparing alternative approalches:

(d) To evaluate the success potential of individual projects. each technology/ process that appears to tit market needs will be investigated for potential barriers to commercialisation. The barrier areas for consideration shall include but not be linited to the following: sechnical. institutional. societal. environmental, economic:

(e) Programme priorities for co-operative reseurch and development for each topic area will be specified on the basis of the outcomes of the first four steps and will include a plan for eventual technology transter:

(f) The responsibilities of each Participant in the atorementioned elements of the Cummon Study will be detined in the detailed work plan the Operating Agent ivill submit (1) the Exccutive Committe pursulant (1) paratgraph 3 below.

\section{Responsibilities of the Operuting tgent}

(a) The Operating Agent, with the assistance of lle other Participants will develop an overall detailed work plan. including meloselolosy and schedule. This plan will be submitted to the Exccutio Committe for approval within three months of the starting day of this Task. This starting waly of this Task will be considered to have uccurred thirty days atrer ivorice of Participacion in this Annex has been given by Paticipants whose cumulative proportions of the annual contribucion exceed 50 per cent.

(b) The Operating Agent will be responsible for incergrating all results into tinal reports and documentation. When approprialc. the leports will include proposed new Task inncxes to accomplish additional aclivities.

(c) The Operating Agent will arrange periodic nectings of experes in encrgy cascading to bring about collaboralion in this lich.

\section{Funding}

(a) The expenditure incurred in the operation of this Task shall be jointly borne by the Participants, as provided in Article 6 (g) of the Agreement, in the proportions determined as provided below. Such expenditure is not expected to exceed $\$ 250.000$ per year at October 1976 price livels and exchange rates, and may not sxceed such level except upon the unanimous

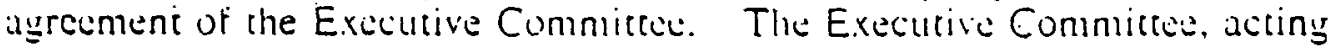
by unanimity. shall adjust the ligure refierred to in this pallagraph al least annually to lake account of changes in sxchange rates and changing price levels in the country of the Operating Agent to ensuce that the necessalty real resources will continue to be available 10 operate the joudy. It signiticant changes in such exchange rates or price levels occur, the Executive Commitcos. acting by unanimity, shall considel whether to adjust the programme of work ro the available funds. 
(b) The Agency Scale of Contributions shall be used to determine financial contributions to the Common Study. For this purpose the Agency percentages of the Participants are to be grided up proportionately so that the sum will be 100 per cent.

If the Agency Scale of Contributions is not applicable to a Participant (e.g. the European Communities), the Executive Committee. acting by unanimity, shall fix a percentage for this Participant.

(c) After the initial two-year period. the Executive Committee shall. acting by unanimity, agree the proportions in which expenditures incurred in the operation of the Task shall be borne by the Participants for each succeeding period.

\section{Time Period}

This Annex shall remain in force for an initial period of two years from the date hereot, and shall continue in force there:after unless and until the Executive Committee, acting by unanimity. decides on its tcrmination.

6. Operating Agent

United States Energy. Research and Development Administration.

\section{Information and Intellectual Property}

(a) Executive Commitree's Powers. The publication. distribution. handling, protection. and ownership of intormation and incellectual property arising from this Allmex / to the IEA Implementing Agrcomint for a Programme of $R$ and $D$ on Energy Conservacion through Encrgy Cascading (hereinatiter

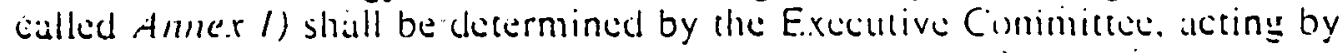
unanimity: in contormity with this Agresment.

(h) Right to Publish. Subject only to copyright restrictions. de Ammer I Participants shall have the right to publish all intormation provided to or arising from thlnex / exceps proprictary information.

(c) Proprieiary liformation. The Ammer / Participants shall tatie all necessary measures in accordance with this paragraph. Wh laws of their esspective countries and international law to protect proprictary intormation. For the purposes of this Annex, proprictary information shall mean information of a confidential nature such as tride secrets and hnow-liow fior example, computer programmes. design procedures and lechniques. chemical com. position of materials, or manuficturing methods. processes. or dreatments) which is appropriately marked. provided such information:

(1) Is not generally known or publicly available from other sources:

(2.) Has not previously been made avalibble by the owner to others without obligation concerning its contidentialicy; or 
(3) Is not already in the possession of the recipient fimlex / Participant without obligation concerning its contidentiality.

It shall be the responsibility of each Participant supplyirg proprietary information to identify the information as such and (1) ensure thate it is appropriately marked.

(d) Production of Relevant Information by Governments. The Operating Agent should encourage the governmints of all Agency Participating Countries to make available or to identify to the Operating Agent all published or otherwise freely available intornation known to them that is relevant to the Task.

(e) Production of Available Information hy Participants. Each Participant agrees to provide to the Operating Agent all previously existing informution. and intormation developed independently of the Tis.sk. which is necded by the Operitting Agent 10 culrry out its lunctions in this Tisk and which is treely at the disposal of the Participant and the transmission of which is nut subject to any contractual andior legal limitations:

(1) If no substancial cost is incured by the Participant in miking such intormation available. at no charge (o) dhe Task chercfor:

(2) If substantial costs must be incurred by lae Participant a make such

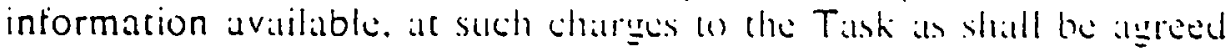
between the Operating Agent and the Participant with the approval of the Exciutive Committes.

(f) Use of Confidential Informarion. If a Participant has access to contidential

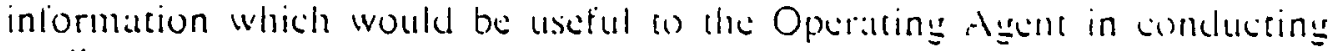
studies. assessments. anailyses. or evaluations, such information may be communicaled to the Operating Agene but shall mot become part of exports or other documentation. nor be communicaled we the ofler Participants except as may be agreed between the Operalting Agente and de Participane which supplies such information.

(g) Acquisition of Iniormation for the Tust. Each Participant shall inform

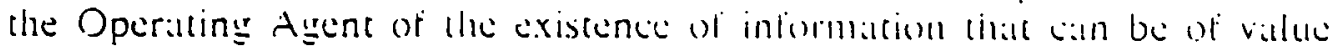
to the Task. but which is nos ficely available. and the Participant shall endeavour to make the information availathle to the Taisk under reasonable conditions. in which event the Executive Cimmilles may. acting by unanimity. decide to acquire such intormation.

(h) Reports on Work Performed under the Tusk. The Operating A Aene stiall provide reports of ill work performed under the Tish and the results thereof, including studies. asscssments. analyscs. evaluations and wher documentation. but excluding propristary intormation. to the Exsutio Committie.

(i) Copyright The Executive Commitces or any member appointed by it. may take appropriate méasures necessary to protect copyrightable material 
generated under this Task. Copyrights obcained shall be the property of the Operating Agent. provided. however. that Annex / Participants may reproduce and distribute such material. but shall not publish it with a view to profit, except as otherwise directed by the Executive Committee.

(j) Authors. Each Anne.r I Participant will. without prejudice to any rights of authors under its national laws. take necessary steps to provide the co-operation from its authors required to carry out the provisions of this paragraph. Each Alner / Participant will assume the responsibility to paly awards or compensation required to be paid to its employees according to the laws of its country.

\section{Additional Provisions}

Each Participant shall be encouraged to nominate an individual to assist the Operating Agent in the management of this Task. Financial arrangements for the travel. per diem and salary costs of such individuals will be decided by the Executive Committee, acting by unanimity.

\section{Results}

The results of these co-operative activities will be:

(a) A report for each technology analysed containing the following:

(1) Description of technology:

(2) Technical potential:

(3) Implomentin! industrics:

(4) Economic potential:

(5) Implementation study:

(6) Descripcion of $R$ and $D$ requircments:

(7) Proposed $R$ and $D$ plian:

(8) Proposed follow-un cosoperative projects:

(b) A summary report at the complection of the Common Study providing an integrated over-vicw of the technologies analysed. and describing all specilic co-operative $R$ and $D$ follow-on projects identilied during the Common Study. The report will contain a catalogute of the cost. performance and market data developed on cascading technologies during the Common Study.

Each Participant will be entitled to receive a copy of each of the reports on the results of the co-operative activities in this Task. 
10. Participants in this Task

The Contracting Parties which are Participants in this Task are the following:

The Republic of Austria.

The Kernforschungsaniage Jülich G.m.b.H. (Germany),

The National Swedish Board for Energy Source Development (Sweden),

The Otfice Fédéral de la Science et de la Recherche du Département Fédéral de l'Intérieur (Switzerland),

The United Scates Energy Research and Development Administration (United States of Americin). 


\section{INTERNATIONAL ENERGY AGENCY}

IMPLEMENTING AGREEMIENT

FOR THE ESTABLISHIIENT OF A PROJECT TO OEMONSTRATE AND PROMOTE THE COMBINED APPLICATION OF THE SCIENCE OF EKISTICS AND ADVANCED ENERGY SYSTEMS

\section{The Contracting Parties}

CONSIDERING that the Contracting Parties, being either governments or parties designated by their respective governments pursuant to Article III of the Guiding Frinciples for Co-operation in the Field of Energy Research and Development adopted by the Governing Board of the International Energy Agency (the "Agency") on 28th Juiy, 1975, wish to take part in the establishment and operetion of a Project to Demonstrate and Promote the Combined Application of the Science of Ekistic and Advanced Energy Systems (the "Project") as provided in this Agreement;

CONSIDERING that the Contracting Parties which are governments and the governments of the other Contracting Parties (reierred to collectively as the "Covernments") participata in the Agency and have agreed in Article 41 of the Agreement on an Internationai Energy Program (the "I.E.P. Agroement") to undertake national programies in the areas set out in Article 42 of the I.E.P. Agresment, including the arez of research and development in energy conservation;

CONSIDERING that in the Governing Board of the Agency on July 28 th 1975 the Governments approved the Project as a special activity under Article 65 of the L.E.P. Agresment;

CONSIDERING that the Agency has recognized the establishment of the Project as an important component of international cooperation in the field of energy conservation research and development;

HAVE AGREED as fOllows: 
Article 1

OBJECTIVES

Introduction

In order to achieve maximum conservation of energy on a community scale, the analytical and design tools and methods traditionaliy used by the urban design and energy systems professions must be reiocused upon the energy considerations in human settlements and combined for joint application by teams consisting of both professions to the problems of human settlements. This project will develop such a practical and widely applicable tool, consisting of a community design methodology and ekisticenergy analytical matrix. Ekistics is a Greek word for the science of human settlements as developed in its modern form by Constantine Doxiades. It offers a detailed analytical matrix of the functional and scale relationships in human settlements, ideal for correlation of energy parameters and synthesis of a generic design and analysis tcol and methodology for. use by urban designers and engineers to maximize energy conservation on a community scale.

Project Objectives

1. Sponsor international cooperation in the area of cormunity development based on the combined application of the science of ekistics and advances community energy systems.

2. Oevelop a practical and wideiy applicable methodology for community desisn. and analysis as a tool for achievement of maximized energy conservation in a resources-limited environment. This methodology in its generic form and through the accompanying guidelines must be suitable for genera? transferability and use in the countries of the Participating Parties.

3. Organize and conduct an international conference in the summer of 1977 on ekistics and innovative community energy systems to encourage ongoing international excinange of information and collaboration in this field.

4. At a future time, by agreement of the Participating Parties, the methodology and related outputs developed under this project may be apolied for a demonstration of the ekistic-energy development of a specific site. 
Article 2

SPECIFICATION OF TASKS

(a) Specific tasks shall be conducted by Participating Parties in accordance with this Agreement, and with annexes hereto. Each proposed annex shall be submittad to the. Executive Cormittae for approval, and shall contain:

(1) A complete description of the scope of work to be carried out by the Participating Parties and the time period for performance of the task;

(2) A designation of a Task Operating Agent who shall have primary responsibility for performance of the task;

(3) A complete description of the functions to be performed by the Task Operating Agent;

(4) An initial budget for the task, together with a specific statement of the funds (if any) to be provided by each of the Participating Parties for periormance of the task and procedures for adopting subsequent budgets for the tas'k;

(5) Provisions specifying the treatment to be afforded to information and intellectual property used in connection with, or developed as a result of the conduct of the task;

(6) Specific provisions on the procurement policies to be adhered to by the Task Operating Agent in periorming the task, together with a statement of the jurisdiction whose laws will'be applicable to the performance of the task;

(7) A statement of the number and irequency of reports to be submitted by the Task. Operating Agent to the Executive Committee.

(b) Upon receipt by the Executive Comittee of a proposed task, it shall notify all Contracting Parties thereof. Upon approval of the proposed task by the Executive Conmittee, it may be executed by the Participating Parties (and by the Task Operating Agent, which shall agree to carry out the function conferred upon $i t$ ) and shall thereupon become an Annex to this Agreement. 
(c) Each Annex shall, unless otherwise provided therein, be subject to the provisions of this Agreement. The provisions of each Annex shall be binding only upon the Participating Parties thereto and to the Task Operating Agent, and shall not affect the rights or obligations of other Contracting Parties to this Agreement.

(d) Each Annex may, with the approval of the Executive Committee, be amended by the Participating Parties thereto. 
Article 3

\section{THE OPERATING AGENTS}

(a) All legal acts required to operate Tasks under this Project shall be performed on behalf of the Particioating Parties by the appropriate Task Operating Agent, which shall, for the benefit of the Participating Parties, be the legal owner of all property rights which may be acquired for the Task or which snall accrue to the Task in carrying out its objectives, subject to Article 7 and relevant Annex provisions regarding Information and Intellectual Property. The Task Operating Agents shall operate the Tasks under their supervision and responsibility, subject to this Agrsement, and unless otherwise provided in the relevant Annex, in accordanca with the law of the country of the Task Operating Agent.

(b) The Task Operating Agents shall have the right to rasign as Task Operating Agents at any time, by giving six months written notice to that effect to the Participating Parties, provided that:

(1) A Contracting Party, or entity proposed by a Contracting Party, is at such time willing to assume the duties and obligations of the Task Operating Acent and so notifies the Participating Parties and the other Contracting Partias in writing not less than three months in advance of the effective data of the Task Operating Agent's resignation; and

(2) The relevant Annex is appropriately amended.

(c) In the event that another Task Operating Agent is appointéd under Paragraph (b) above, the Task Operating Agent shall transfer to such replacement Task Operating Agent all property rights which it may have acquired under Paragraph (a) above.

(d) The Task Operating Agents shall be reimbursed from the funds made available by the Participating Parties pursuant to the relevant Annex for its expenses and costs associated with actions taken in accordance with this Agreement. The Task Operating Agents shall without prejudice to the provisions of Article $6(c)$ receive no fee or other emolument apart from such reimbursement.

(e) The Task Operating Aģents shall have po'wer to enter into agreements for the appointment of consultants, construction of plant, and procurement of materials in the interest of a task provided that such agreements are allowed for in the Task Bucget and by the provisions of the Task Annex. 
(f) The Task Operating Agents shall procure quotations and tenders, and let and administer all agreements for the construction of plant or procurement of materials in accordance with the applicable procurement procedures as specified in the Annex. 
Article 4

THE EXECUTTVE COMMITTEE

(a) Subject to the direction of the Participating Parties with respect to each Task, overall control of the Project shall be vested in an Executive Comittee constituted in accordance with this Article.

(b) The Executive Committee shall consist of one member designated by each Contracting Party; each Contracting Party shall also designate an alternate member who shall represent the Contracting Party if the member is unable to do so. Each Contracting Party shall inform the Executive Cormittee in writing of all designations under this paragraph. The Executive Comittee sha11:

(1) Approve each year the Programme of Work of the Project, toçether with an indicative programe of work and budget for the following two years; the Executive Committee may, as required, make adjustments within the framework of the Programme of Work and Budget;

(2) Make such rules and regulations as may be required for the sound management of the Tasks, including iinancial rules as provided in Article $6(c)$;

(3) Consider any matters submitted to it by the Task Operating Agents or any Contracting Party; and.

(4) Carry out the other functions conferred upon it by this Agreement and the applicable Annex.

(c) The Executive Committes shall each year elect a Chairman and one or mors Vice-Chairmen.

(d) The Executive Committee may establish such subsidiary bodies and rulas of procedure as are required for the proper functioning of the Committses. A representative of the Agency and a representative of each Task Operating Agent (in its capacity as such) may attend meetings of the Executive Committae and its subsidiary bodies in an advisory capacity.

(e) The Executive Committee shall meet in regular session twica each year; in extraordinary circumstances a special meeting shall be convened upon the request of a Contracting Party which can demonstrate the need therefor.

(f) At least twenty-eight days before each meeting of the Executive Comittis notice of the time, place and purpose of the mesting shall be given to 
each Contracting Party and to other persons or entities entitled to attend the meeting; notice need not be given to any person or entity otherwise entitled thereto if notice is aived before or after the mesting. The quorum for the transaction of business in meetings of the Executive Committee shall be one-half of the members plus one (less any resulting iraction).

(g) With the agreement of each Contracting Party, a decision or recommendation may be made by telex or cable without the necessity for calling a meeting. The Chairman of the Executive Conmitiee shall have the responsibility of ensuring that all Contracting Parties are informed of each decision or recommendation made pursuant to this paragraph.

(h) Where this Agresment requires the Executive Committee to act by unanimity, this shall require the agreement of each member or alternate member present and voting at the mesting at which the decision is taken. The Executive Comittae shall adopt decisions and recommendations, for which no express voting provision is made in this Agreement, by majority vote of the members or alternate members present and voting, provided that any decision affecting the conduct of a particular Task sha!l require the aifirmative vote of each Contracting Party which is a Participating Party with respect to that Task.

(i) The Executive Committee sha17, at least annually, provide the Agency with periodic reports on the progress of the Task. 


\section{Article 5}

\section{ADMINISTRATION AND STAFF}

(a) Each Task Operating Agent shall be responsible to the Executive Comittee and to the Participating Parties for the operation of the Task in accordance with this Agreement and its applicable annexes, the annual Programe of work and Budget, decisions of the Executive Comittee and the regulations of the establishment at which the work is carried out.

(b) Each Task Operatini Agent shall suppiy to the Executive Conmittes such information concerning the progress of the Task as the Committes may request and shall each year submit, not iatar than two months after the and of the financial year, a report on the progress of the Task to the Executive Committes.

(c) The staff for such Task shall be selected by the Task Operating Agent in accordance with rules determined by the Executive Committee and shall be responsible to the Operating Agent. The Participating Parties (or organizations or other entities designated by Contracting Parties) may propose personnel to work on the staff; and such stafi, if selected, shall be made availaole, by secondment or otherwise, to the Task.

(d) Staff members shall be remunerated by their respective employers and shall, except es provided in this Agreement or in applicable appendices, be subject to their employers' conditions oi service. 


\section{Article 6}

\section{FINANCE}

(a) The specific financial obligations of Participating Parties shall be specified in each Annex.

(b) Any income accruing from the performance of a Task shall be credited to the budget of that Task.

(c) The Executive Committee, acting by unanimity, shall make such rules and regulations as may be required for the sount financial management of the Project. These rules shall, unless otherwise provided in a specific Annex, apply to all Tasks performed under the Project, and shall:

(1) Establish procurement procedures to be used by the Task Operating Agents in making contracts or otherwise expending funds for the Tasks;

(2) Establish the level of expenditure for which Exacutive Committee approval and/or approval by each Participating Party in a specific Task will be required, including expenditure invclving payment of monies to the Task Operating Agents for other than routine salary and administrative expenses previously approved in the Budget process;

(3) Require that contributions received by the Task Operating Agent shall be used solely in accordance with the Programe of Work and Budget.

(d) The system of accounts employed by the Task Operating Agents shall be in accordance with accounting principles generally accepted in the country of the Task Operating Agent and consistantly applied. Each Operating Agent shall maintain completa, separate financiai records which shall clearly account for all funds and property coming into the custody or possession of the Task Operating Agent in connection with the performance of the Tasks.

(e) Unless otherwise provided in a specific Annex:

(1) The financial year of the Tas'k shall correspond to the financial year of the Task Operating Agent;

(2) Each Task Operating Agent shall each year propare and, with the concurrence of the Participating Parties to that Task, sutmit 
to the Executive Cormittee for approval a draft programme of work and budget, together with an indicative progranme of work and budget for the following two years, not later than three months before the beginning of each financial year;

(3) Not later than three months after the close of each financial year, each Task Operating Agent shall submit for audit the annual accounts of the Tas'k in a form approved by the Executive Committee to auditors selected by the Executive Cormittee and shall present the accounts together with the auditors' report to the Executive Cormittee for approval;

(4) All books of account and records maintained by the Task Operating Agent shall be preserved for at least three years from the date of termination of the Task.

(f) Each Contracting Party shall bear all costs of its participation in the Project.

(g) Each Participating Party shall heve the right, at its sole cost, to audit the accounts of the Task on the following terms:

(1) The Participating Party shall provide the other Contracting Parties with en opportunity to participate in such audits on a cost-shared basis;

(2) The accounts and records in respect of the Task Operating Agent's activities other than those for the Task shall be excluded from such audit, but if the Contracting Party concerned requires verificiation of charges to the sudget representing services rendered to the Task by the Task Operating Agent, it may at its own cost request and obtain an audit certiificate in this respect from the Task Operating Agent's external auditors;

(3) Not more than one such audit shall be required for any Task in any financial year. 


\section{Article 7}

\section{INFORMATION AND INTELLECTUAL PROPERTY}

It is expected that each Task agreed to pursuant to this Agreement will, in its particular Annex, specify the provisions on information and intellectual property to be applicable therato. In general, the General Guidelines concerning Information and Intellectual Property, (IEA Document (IEA/SLT/75) 58, 3d Rev.), shall be taken into account in developing each such Annex. 
Article 8

LEGAL RESPONSIBILITY AND INSURANCE

(a) Each Task Operating Agent shall use all reasonable skill and care in carrying out its duties under this Agreement and relevant Annexes and shall be responsible for ensuring that the Task is conducted in accordance with all applicable laws and regulations. Except as otherwise provided in this Agreement or its Arnexes, the cost of all damage to property and all legal liabilities, claims, actions, costs and expenses connected therewith shall be charged to the Budget of the'relevant Task or Tasks.

(b) Each Task Operating Agent shall propose to the Executive Committae necessary liability, fire and other insurance. The Tas' Operating Agent shall carry such insurance as the Executive Committes may direct. The cost of obtaining and maintaining insurance shall be charged to the sudget of the Task.

(c) Each Task Operating Agent shall be liable, in its capacity as Task Operating Agent, to idemnify the contracting Parties against the cost of any damage to property and against all legal liabilities, actions, claims, costs and expenses connected therewith to the extent that they:

(1) Result from the failure of the Task Operating Agent to maintain any such insurance it is required to maintain under paragraph (b) above; or

(2) Result from the gross negligence or wiliul misconduct of any of the Task Operating Agent's employees or officars Carrying out its duties under this Agreement and rleevant Annexes. 


\section{Article 9}

\section{LEGISLATIVE PROVISIONS}

(a) Each Contracting Party shall, within the framework of applicable legislation, usa its best endeavours to facilitate the accomplishment of formalities involved in the movement of persons, the importation of materials and equipment and the transier of currency which shall be required to conduct a Task.

(b) The participation of each Contracting Party in the Project and in any Task shall be subject to the appropriation of funds by the appropriate governmenta? authority, where necessary, and to the constitution, laws and requiations applicable to the contracting Party, including, but not limitad to, laws establishing prohibitions upon the payment of commissions, percentages, brokerage or contingent fees to persons retained to solicit governmental contracts, and upon any share of such contracts accruing to governmental oificials.

(c) Each Task shall in its operations take account, as aporopriate, of the Guiding Principles for Cooperation in the Field of Energy Research and.Development, and any modification thereof', as well as other decisions of the Governing Board oi the Agency in that field. The temination of those Guiding Principles shall not affect this Agresment which shall rema in in force in accordance with the terms hereof.

(d) Any dispute among two or more Contracting Parties concerning the interpretation or the application of this Agresment or its Annexes which is nöt settled by negotiation or other agreed mode of settlement shal1 be referred to a tribunal of three arbitrators to be chosen by the Contracting Parties concerned who shall also choose the Chaiman of the tribunal. Should the Contracting Parties concerned fail to agree upon the composition of the tribunal or the selection of the Chairman, the President of the International Court of Justice shall, at the request of any of the Contracting Parties concerned, exercise those responsibilities. The tribunal shall decide any such dispute by reference to the terms of this Agreement and any applicable laws and regulations, and its decision on a question of fact shall be final and binding on the contracting Parties concerned. Each Task Operating Agent shall be regarded as a Contracting Party for the purposes of this paragrapn where the dispute involves performance of a Task for which it is Task Operating Agent. 


\section{Article 10}

\section{ADOITION AND WITHORAWAL OF CONTRACTING PARTIES}

(a) Upon the invitation of the Executive Committee, acting by unanimity, participation in the Project as a Contracting Party shall be open to the government of any Agency Participating Country (or a national agency, public organization, private corporation, company or other entity proposed by such government), which signs this Agreement and assumes the rights and obligations of a Contracting Party. Such participation shall be effective upon the adoption by the Executive Comittes of consequential. amendments to this Agreement.

(b) The government of any other Member of the Organization for Economic Cooperation and Development may, on the proposal of the Executive Committee, acting by unanimity, be invited by the Governing soard of the Agency to participate in the Project as a Contracting Party (or to propose a national agency, public organization, private corporation, company, or other entity to do so), to sign this Agreement, and to assume the rights and obligations of a Contracting Party. Such participation shall be efiective upon the adoption by the Executive Comittee of consequential amendments to this Agreement.

(c) The European Communities may participate in the Project in accordance with arrangements to be made with the Executive Committee, acting by unanimity.

(d) It shall be a condition of participation in any specific Task of any new Contracting Party under paragraph (a) or (b) above, or participation under paragraph (c) above, that the Contracting Party or participant shall contribute, in accordance with rules laid down by the Executive Committee, an appropriate proportion of the expenditure of the Task prior to the date of such participation.

(e) With the agreement of the Executive Committas, acting by unanimity, and upon the request of a Government, a Contracting Party proposed by that Government may be replaced by enother party. The replacement party shall sign this Agreement and assume the rights and obligations of a Contracting Party.

(f) Any Contracting Perty may withdra'w from this Agreement, or from any specific tasks agreed to by annex, at any time with the agreement of the Executive Committes, acting by unanimity, or by giving twelve month written notice to that effect to the Executive Commitiee, such notica to be given not earlier. than two years aiter the date hereaf. The withdrawal of a Contracting Party under this paragraph 
shall not affect the rights and obligations of the continuing Contracting Parties, except that the proportionate shares of any affected Task 8udget shall be adjusted to take account of such withdrawa1.

(g) A Contracting Party serving as a Task Operating Agent which withdraws from this Agreement under paragraph ( $f$ ) above, shall cease to be the Operating Agent and shall account to the Executive Committee, unless the Executive Comittee, acting by unanimity, agrees to retain the former Contracting Party as Task Operating. Agent.

(h) A Contracting Party other than a Government shall forthwith notify the Executive Comittee of any significant change in its status or ownership or of its becoming bankrupt or entering into liquidation. The Executive Committae shall detarmine whether any change in status or ownership or bankrupicy or liquidation of a Contracting Party significantly affects the interests of the other Contracting Parties; if the Executive Conmittee so determines, then, unless the Executive Committee, acting upon the unanimous decision of the other Contracting Parties, otherwise agrees:

(1) That Contracting Party shall be deemed to have withdrawn from the Agreement under paragraph ( $f$ ) above on a date to be fixed by the Executive Committee; and

(2) The Executive Committee shall invite the Government which proposed that Contracting Party to propose (within a period of three months of the withdrawal of that Contracting Party) a different entity to become a Contracting Party and, if approved by the Executive Comitiee, acting by unianimity, such entity shall become a Contracting Party with eifect irom the date on which it signs this Agreement and assumes the rights and obligations of a Contracting Party.

(i) Any Contracting Party which fails to fulfill its obligations under this Agreement within sixty days aiter its receipt of notice invoking this paragraph and speciiying the nature of those obligations, may be deemed by the Executive Cormittee, acting upon the unanimous decision of the other contracting Parties, to have withdrawn from this Agreement. 


\section{Article 11}

\section{FINAL PROVISIONS}

(a) This Agreement shall remain in force for an initial period of seven. years from the date hereof and shall continue in force thereafter unless and until the Executive Committee, acting by unanimity, decides on its termination.

(b) Nothing in this Agreement or its annexes shall be regarded as constituting a partnership between the Contracting Parties or any of them.

(c) Upon termination of this Agreement, or any annex to this Agreement, the Executive Committee acting by unanimity shall decide upon the liquidation of the assats of the Task in whole or part and any distribution which might be made to the present and former contracting Parties. The executive Comittes shali, so far as practicable, distribute the assets of the Task, or the proceeds therefrom, in proportion to the contributions which the Participating Parties have made from the beginning of the operation of the Task, and for that purpose shall take into account the contributions and any outstanding obligations of former Contracting Parties. Ois putes with a former contracting Party about the proportion allocatad to it under this paragraph shall be settled under Article $g(d)$ and for that purpose a former Contracting Party shall be regarded as a Contracting Party.

(d) This Agreement may be amended at any time upon the unanimous agreement of the Contracting Parties. Such amendments shall come into force in a manner detarmined by the unanimous agreement of the Contracting Parties.

(e) The original of this Agreement shall be deposited with the Executive Director of the Agency, and a certified copy thereof shail be iurnished to each Contracting Party. A copy of this Agreement shall be furnished to each Agency Participating Country, to each ihember country of the Organization for Economic Cooperation and Development and to the European Communities. 


\section{ANNEX A}

\section{AGREEMENT}

\section{Between}

THE ENERGY RESEARCH AND DEVELOPMENT ADMINISTRATION ( ERDA) OF THE UNITED STATES OF AMERICA

\section{And}

THE NATIONAL ENERGY COUNCIL OF THE MINISTRY OF COORDINATION OF THE REPUBLIC GF. GREECE

For a Task

Titled: "Development of a Methodology for Combined Application of the Science of Ekistics and Advanced Community Energy Systems"

Under the

INTERNATIONAL ENERGY AGENCY

IMPLEMUNTING AGREEMENT

For the establishment of a project to demonstrate and promote the combined application of the Science of Existics and Advanced Energy Systems. 
I. Introduction

A. Background

In order to achieve maximum conservation of energy on a commurity scale, the analytical and design tools and methods traditionally used by the urban design and energy systems professions must be refocused upon the energy considerations in human settlements and combined for joint application by teams consisting of both professions to the problems of human settlements. This task will develop such a practical and widely applicable tool, consisting of a community design methodology and ekistic-energy analytical matrix. Ekistics is a Greek word for the science of human settlements as developed in its modern form by Constantine Doxiades. It offers a detailed analytical matrix of the functional and scale relationships in human settlements, ideal for correlation of energy parameters and synthesis of a generic design and analysis tool and methodology for use by urban designers and engineers to maximize energy conservation on a community scale.

B. Task Objectives

1. Sponsor international cooperation in the area of community development based on the combined application of the science of ekistics and advanced community energy systems.

2. Develop a .practical and ividely applicable methodology for community design and analysis as a tool for achievement of maximized energy conservation in a resources-limited environment. This methodology in. its generic form and through the accompanying guidelines must be suitable for immediate transferability and use in the U.S. environment.

3. Organize and conduct an intarnational conference in the sumer of 1977 on ekistics and innovative community energy systems to encourage on-going international exchange of information and collaboration in this field.

4. At a future time, by mutual agreement, the methodology and related outputs developed under this task may be applied for a demonstration of the ekistic-energy cevelopment of a specific site. 
II. Specification of Task

Develop a Methodology for Combined Application of the Science of Existics and Advanced Community Energy Systems.

A. Subtask 1: Oevelooment of Methodolooy, Scope of Work

1. General Requirements

The designated Operating Agent will de:elop a practical and universally transferable methodology for energy conserving community planning in a resources-limited environment based on ekistics and the use of advanced community energy systems. Practicality and transferability shall be assured by development of the methodology through step-by-step appiication of the ekistic matrix, and the energy parameters thereof, to the generic realities and pctentials of a test-case site translated to the general case for widespread transferability. The Operating Agent shall prepare a report of all work covered in this Scope of Work, with particular emphasis on a clear presentation of the practical and transferable methodology developed, within 12 months from the entry into force of this Annex as a deliverable to the U.S. ERDA.

2. Specific. work items in Subtask 1 include:

a. - Detailed work management plan and budget for subtasks 1 and 2 and test-case site selection rationale recommendation. A report on these items shall be submitted to the Executfve Committee for review and approval prior to proceeding with other work items.

b. Preliminary formulation of the methodology to be used and refined during application to the site. The methodology will include the use of -

(1) ekistic matrixes, including energy parameters

2) parameters of advanced energy systems

(3) socio-economic feasibility criteria

(4) engineering-economic feasibility criteria

(5) planning framework for economic and existic land-use development

(6) procedures for choosing a balanced existic-energy economic development 
c. Methodology development tasks:

(1) Inventory and evaluation of potential natural resources of the sita, including hydroiogical and insolation surveys; define process for the general casse.

(2) Societal definition of human resources and needs, including analyses of local socio-economic structure; define process for the genera? case.

(3) Analysis and definition of economic deveiopment potentials of the site; define process for the general case.

d. Development of socio-economic and engineering-economic feasibility criteria, guidelines, and limiting conditions for the general case and the site.

e. Application of the preliminary methodology to the site to produce altsrnative preliminary land-use and economic development master plans. These plans will display alternative ways of using natural and human resources to exploit economic development potential, assuming availability of required energy and water at the site. Energy consuming end-use services required will be specified by amount and type. Refine preliminary methodology for the general case.

f. Development of a community energy and utilities suppiy system that fully supports each alternative mastar olan. These systems will give full coverage to traditional energy sources and to use of solar and other non-depletable forms of energy. They will be based on maximum community-wide energy eificiency from energy production through conversion, distribution, and end-use. In this work item the Operating Agent will borrow and adapt ongoing work under EROA's Advanced Technology Mix Energy Systems (ATilES) Program. Refine preliminary methodology for the general case.

g. Development of a recommended mastar pian for full development of the site, including cost estimates and a preliminar: engineering description of the energy system winich will serve it. Define process for the general case. 
h. Development and presentation of a phased development plan for implementation of the master plan, complete with budget for economic and social investment for each phase and with recommended organizational approaches. Define process for the general case.

i. Documentation of the complete methodology as refined by application to the site, including illustrations, examples and instructions adequate for generalized use by urban planners, engineers and related professionals.

8. Subtask 2: International Conference on Ekistics and Innovative Community Eneray Systems

1. The Operating Agent, shall undertake and carry out an international conference on ekistics and innovative community energy systems in Athens, in the summer of 1977. The conference shall be co-sponsored by the National Energy Council and ERDA. This conference will encourage international exchange of information and collaboration on apolications of ekistics and advanced energy systems to new and old communities. Subjects to be covered include -

a. Technological and scientific developments in ekistics, urban planning, and community energy systems.

b. Government projects for regional economic development which.can profit from ekistics planning techniques and advanced energy systems.

2. The widest possible participation by countries in the confersns: shall be sought, and a wide scope of presentations by these representatives shall be encouraged as long as they relate to the main subjects of the conierenca.

3. The Operating Agent, shall undertake all activities required to successfuily convene and carry out the conference, including the preparation and dissemination of printad proceedings of the conference. The Executive Committee shall approve the detailed budget for the conference, the guidelines for international participation and the detailed agenda of the conierenca 
III. Designation and Specific Outies of the Ooerating Acent

A. The National Energy Council of the Ministry of Coordination of the Republic of Greece is designated the Operating Agent for this Task.

B. The specific duties of the Operating Agent are as follows:

1. Provide full project management services for accomplishment of. work as specified in the Task Specification and the Task Schedule.

2. In accordance with the Task Schedule, submit to the Executive Committes for aporoval a detailed work management olan and budget including identification of energy and ekistics consultants to be used in Subtask 1 and organization to be assigned execution of Subtask 2.

3. Ensure delivery of the work products to the Participating Parties in accordence with the Task Schedule. Submit the Subtask $I$ final report and the conference proceedings to the Executive Committee.

IV. Obligation of the Energy Research and Develocment Administration TERDA) of U.S.A.

A. ERDA shall, within two months from the signing of this Agreement provide the Operating Agent with relevant information on those advanced community energy systams, derivable from ERQA RO\&D programs, which could have potential application compatible with the nature and general requirements of the test-case site.

8. During the course of the Project ERDA will provide information, guidance and comments concerning the energy systams corisidered under the Task.

C. Following completion of work item II.A.2.e, ERDA personnel associated with the ATMES program shall consult with counterpart personnel of the Operating Agent with the objective ci selecting and defining the community energy system to serve each of the a) ternative land use/development plans. 
V. Task Management and Task Schedule

\section{A. Task Management}

1. Supervision of the Task shall be vested in a Executive Committee as constituted herein and decisions reached by the Executive Committee shall be binding on the Operating Agent and each Participating Party.

2. The Executive Comittee shall consist of one representative designateo by each of the Participating Parties. Each member of the Executive Committee may appoint technical or other advisers. Each Participating Party shall inform the other Participating Parties in writing oi all designations under this paragraph:

3. The Executive Committes shall evaluate performance of work and Task results by the Operating Agent, and shall take such actions as are necessary for the efiective managenent of the Task in accordance with the Task Schedule.

4. The Executive Comittes shall adopt the detailed Task Budget and detailed work management plan and shall make such rules and regulations as may be required for the sound management of the Task.

5. Members of the Executive Committee shall be remunerated by their respective employers and shall be subject to their employers conditions of service.

6. Each member of the Executive Committee shall have one vote, and all decisions shall be by unanimity.

7. The Executive Cormittee shall meet in regular session at least twice annually during the duration of the Task; each Participating Party shall have the right to raquest additiona? sessions. Meetings of the Executive Committee shall be held at such locations as may be mutually agreed upon. All members of the Executive Commities shall be present to produce a quorum for the transaction of business in meetings of the Executive Cc.... mittee. With the agreement of each representative in the Executive Committee, a decision or recommendation may be made by Telex or cable without the necessity for calling a meeting. 
B. Task Schedule

The Operating Agent undertakes the obligation to complete and submit to the participating Parties all work related to the Project within twelve (12) months from the signing of this Task Agreement.

The Operating Agent will follow the following time schedule:

\section{PHASE 1}

Within thirty (30) days from the signing of the respective contract the Operating Agent must submit to the Executive Committee.

a. A detailed work management plan and budget for the Task.

b. Data and recommendations for the selection of a specific test-case site for the development of the Methodology.

The approval and/or any comments by the Executive Committee on the first phase must be communicated in writing to the Operating Agent no later than thirty (30) days from the date of its submission.

\section{PHASE 2}

Within four (4) months from the date of the written approval to the Operating Agent of the work of Phase 1 the Operating Agent must complete and submit the following items of work to the Executive Comnittes.

a. Completa definition of the preliminary methodology for the combined Existic-Energy methods with a briei description of it.

b. Alternative land-use and economic development schemes.

c. Definition of necessary end-use energy consuming services by type and quantity and of other servicas required by the community.

d. Presentation of Alternative Plans for joint selection of the suitable energy system that covers the repuirements of each land-use and economic deveiopment plan. 
e. Preparation and Program for the organization of an International Conference on Ekistics and Innovative Community Energy Systems.

The approval and/or any comrents by the Executive Committee on the material of the Second Phase must be communicated in writing to the Operating Agent within twenty (20) days from the fulfillment by the Operating. Agent of all the obligations of the Second Phase.

3. PHASE 3

Within four (4) months from the date of the written approval or of any comments by the Executive Committee to the Operating Agent on the material of the sacond phase the Operating Agent must complete and submit the following items of work:

a. Complete workable, analytic ekistic-energy matrix and methods and design methodology to incorporate complete, specific, community energy and recycling systans, for the land-use economic development schemes.

b. Justified choice of the preferred land-use economic development scheme and ekistic-energy development master plan.

c. Organize and hold International Conference in Greece on existics and innovative community energy systems.

The approval and/or any comments of the Executive Committes on the material of the Third Phase must be communicatad in writing to the Operating Agent within tiventy (20) days from the fulfillment by the Operating Agent oi all the obligations of the Third Phase.

\section{PHASE 4}

Within one (1) month from the date of the written approval or of any comments by the Executive Committee to the Operating Agent on the material of the Third Phase the Operating figent must:

a. Submit the Final Text of the Subtask No. 1 Report as particularly called for in subparagraphs. II.A.l and II.A.2. $i$ above in English and Greek and in thirty (30) 
copies in each language. Also the Operating Agent must within thirty (30) days from the date of the submission of the Final Text of this Report submit to the Executive Committee thirty. (30). copies in English and thirty (30) copies in Greek of the Final Text of this Report in the form of a General Report including the drawings developed under the Tas' as 'well as thirity (30) copies of a Summary Report with respective drawings in English and thirty (30) copies in Greek of the same Summary Report.

b. Within two (2) months from the date of the end of the International Conferance the Operating Agent must publish and distribute to the participants the Proceedings of the Conference in Engli.sh.

VI. Financial Terms for the Task

1. The expenditure incurred in the operation of this Task for one year shall be borne by the Participating parties in the proportions appearing below. Such expenditure is not expected to exceed $\$ 200,000$ at October, 1976, price levels and exchange rates, and may not excsed such level except upon the unanimous agreement of the Executive Comnittee. The Executive Committee acting by unanimity, shall adjust the figure referred to in this paragraph at hali-yearly intervals to take account of changes in exchange rates and changing price levels in the country of the Operating Agent to ensure that the necessary real resources will continue to be available to periorm the task. If significant changes in such exchange rates or price leveis occur, the Executive Comittes, acting by unanimity, shall consider whether to adjust the program of work to the available funds. The financial year of the Task shall correspond to the financial year of the U.S. ERDA.

2. Specific financial proportions for each Contracting Party to the Task.

\section{Participating Party}

U.S. Energy Researci \& Cevelopment Administration (ERDA)

National Energy Council of the Ministry of Coordination of the Republic of Greece
Proportion

$75 \%$

25\% 
3. The percentages above will be revised if other IEA member countries express interest in participating in this Annex.

4. The payment of the expenses for each phase of this Project will be prepaid by the Participating Parties in their proportion to a special account of the Public Investments of the Ministry of Coordination of the Republic of Greece. Prepayment of the U.S. ERDA financial proportion shall be made as follows: $20 \%$ of the proportion within fifteen (15) days following signing of this agreement; $80 \%$ of the proportion within fifteen (15) days following approval of the detailed work management plan and budget by the Executive Committee.

VII. Procurement Procedures

The Operating Agent shall competitively procure necessary contractor services for Subtasks 1 and 2 in accordance with the standard procurement procedures normally required for procurement of similar services by the Operating Agent. The laws of Greece shall be applicable.

VIII. Time Period for which this Annex will Remain in Efiect

One year, subject to extension by the Executive Committee for. work slippage as approved by the Executive Comittee.

IX. Patents and Intellectual Prooerty

A. The publication, distribution, handling, protection and ownership of information and intellectual property arising from this task shall be determined by the Executive Committes in conformity with this Agreement.

8. Subject only to restriction applying to patents and copyrights, the Participating Parties shall have the right to publish all information provided to or arising from this task excapt proprietary information. Proprietary information snall not be accepted for or utilized in this Task without express approval of the Executive Committee.

For the purpose of this Section IX, proprietary information shall mean information of a confidential nature such as trade secrets and know-how (for example, computer programes, design procedures and techniques, chemical composition of materials, or manufacturing methods, processes, or treatments) which is appropriately marked, provided such iniormation: 
1. Is not generally known or publicly ayailable from other sources;

2. Has not previously been made available by the owner to other without obligation concerning its confidentiality; and

3. Is not already in the possession of the recipient Participating Parties without obligation concerning its coniidentiality.

The Operating Agent and the Participating Parties shall take all necessary measures in accordance with this Section IX, the laws of their respective countries and international law to protect proprietary information.

C. The Operating Agent shall provide the raports requirad in this Annex without restriction to each Participating Party. Each Participating Party shall be entitled to the following additional information: information: prior to the reginning of the task
1. Information related to the task which has not been held conEf Givizino fidentialiby the operating Agent, its subcontra Subject to the approval deseribed in $\mid X \quad B$,

2. Aroprietary information of the Operating Agent or the Participating Parties related to the task for use only in relation to each Participating Party's research and development programmes.

D. The U.S. ERDA shall license proprietary information ralated to the task and which has been utilized in the task:

1. Royalty-free to the Government of each Participating Party for governmental use in its country only; and

2. On reasonable terms and conditions to the Participating Parties, their Governments and nationals of their countries designated by the Participating Parties ior use in all countries.

E. Each Participating Party agrees to license, on reasonable terms and conditions, all patents owned or controlled by it which are useful in practicing the results of the task and have been utilized in the task, to the Participating Parties, their Governments and the nationals of their countries designated by the Participating Parties for use in all countries. 
F. Patents owned or controlled, in whole or in part, by parties other than Participating Parties may be procured by or licensed to the Operating Agent for use in the task only with express approval of and under terms and conditions stipulated by the Executive Committee.

G. Inventions made or concaived in the course of or under the Task (arising inventions) shall be identified promptly and reported by the Operating Agent along with a recommendation of the countries in which patent applications should be ijled. The Executive Committee shall establish procedures

for processing such recommendations to determine where and when patent applications will be filed at the expense of the task.

Information regarding inventions on which patent protection is to be obtained shall not be published or publicly disclosed by the Operating Acent or the Participating Parties until a patent apolication has been filed in any of the countries of the Participating Parties, provided, however, that this restriction on publication or disclosure shall not extend beyond six months from the date of reporting of the invention. It shall be the responsibility of the Operating Agent to eppropriately mark task reports which disclose inventions thet have not been appropriately protected by the filing of a patent application.

H. Patents obtained on inventions arising from the task shall be owned by:

1. Each Participating Party in its own country, subject to a nonexclusive, irrevocable, royalty-iree licence to the other Participating Parties the nationals of their countries designated by the Participating Party; and

2. U.S. ERDA in all countries, subject to a nonexclusive, irrevocable, royalty-free licence to the other Participating Parties and their Governments, and on reasonable terms and conditions to the nationals of their countries designated by the Participating Party.

I. The Operating Agent shall take appropriate measures necessary to protect copyrightabie matarial generated under the Task. Copyrights obtained shall be the property of the Operating agent for the beneitit of the Participating Parties, provided, however, that the Participating Parties may reproduce and distribute such material, but shall not publish it with a view to profit. 
J. Each Participating Party and the Operating Agent will, without prejudice to any rights of inventors or authors under its national laws, take all necessary steps to provide the cooperation from its authors and inventors required to carry out the provisions of this Section. Each Participating Party will assume the responsibility to pay awards or compensation raquired to be paid to its employees according to the laws of its country.

K. The Executive Committee may establish guidelines to determine what constitutes a "national" of a Participating Party. Disputes that cannot be settled by the Executive Commitiae shall be settled under Article $g(d)$ of the Implementing Agrement for the Establishment of a Project to Demonstrate and Promote the Combined Application of the Science of Existics and Advanced Energy Systems. 
14

Done in Washington, O. C. this 29 th day of October, 1976.

For the National Energy Council of the Ministry of Coordination for and on behalf of the Government of the Republic of Greece.

(Authority for execution of this

Agreement is provided by Presidential

Decree issued on the basis of

Article 4 Paragraph 1 of Law 84/1975).

Elis P. Gyttopouls

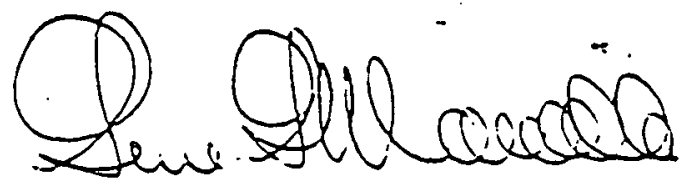

For the Energy Research and Development Administration for and on behalf of the Government of the United States of America. (Authority for execution of this agreement is provided by the Energy Reorganization Act of 1974, P.L. $93-438)$. 
INTERNATIONAL ENERGY AGENCY

\section{IMPLEMENTING AGREEMENT}

FOR A PROGRAMIME OF RESEARCH

AND DEVELOPMENT ON THE APPLICATION

OF HEAT PUMP SYSTEMS

TO ENERGY CONSERVATION 
INTERNATIONAL ENERGY AGENCY

\title{
IMPLEMENTING AGREEMENT
}

\author{
FOR A PROGRAMME OF RESEARCH \\ AND DEVELOPMENT ON THE APPLICATION \\ OF HEAT PUMP SYSTEMS \\ TO ENERGY CONSERVATION
}

TABLE OF CONTENTS

PREAMBLE

Aricle 1

OBjectives

Hricle :

The Executive Committee

Aricle 3

ThE OPERATING AGENT

Article $t$

AOMINISTRATION AiND STAFF

9

Aricle 5

Finaivce

Aricle 6

Information and INTElifectlal. Property 
Article $T$

LEGAL RESPONSIBIIITY .................... 12

Arricle $s$

Legisl.tive Provisions . . . . . . . . . . . . . . . . . 13

Aricle 9

AOMISSION AND WITHORALAL OF CONTRACTINC PARTIES

Aricle 10

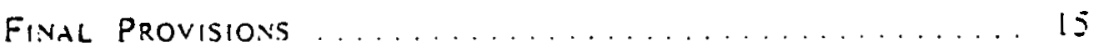

ANNEX

Heat Plimp Systens ivith Thermal: Storatie ......... it 


\section{IMPLEMENTING AGREEMENT \\ FOR A PROGRAMME OF RESEARCH \\ AND DEVELOPMENT ON THE A.PPLICATION \\ OF HEAT PUMP SYSTEMS \\ TO ENERGY CONSERVATION}

The Contracting Parties

ConstDering that the Contracting Parties. being either governments or international organisations or parties designated by their respective governments pursuant to Article III of the Guiding Principles for Co-operation in the Field of Energy Research and Development adopted by the Governing Board of the International Energy Agency (the "Agency") on 28th July. 1975, wish to take part in the establishment and operation of a Programme of Research and Development on the Application of Heat Pump Systems to Energy Conservation (the "Programme") as provided in this Agreement:

Considerivg that the Contracting Parties which are governments and the governments of the other Contracting Parties. (referred to collectively as the "Governments") participate in the Agency and have agreed in Article 41 of the Agreement on an International Energy Program (the "I.E.P. Agreement") to undertake national programmes in the areas set out in Article +2 of the I.E.P. Agreement. including research and development on energy conservation in which field the Programme will be carried out;

Considering that in the Governing Board of the Agency on 28th July. 1975. the Governments approved the. Programme as a special activity under Article 65 of the I.E.P. Agreement; 


\section{PAGES 2 to 5 WERE INTENTIONALLY LEFT BLANK}


CONSIDERING that the Agency hus recognised the establishment of the Programme as an important component of international co-operation in the field of energy conservation research and development;

HAVE AGREED as follows:

Article 1

OBJECTIVES

(a) Scope of Activiry. The Programme to be carried out by the Contracting Parties within the tramework of this Agreement shall consist of co-operative research. development. demonstrations and exchanges of information regarding the application of heat pump systems to energy conservation.

(b) Method of Implementation. Each Contracting Party shall implement the Programme by undertaking one or more Tusks as provided in the attached Annex.

(c) Task Co-ordination and Co-operation. The Contracting Parties shall cooperate in co-ordinating the work of the various Tasks in the attached Annex and in advancing the research and development activities of all Contracting Parties in the field of energy conservation.

(d) Additional Tasks. Additional Tasks may be joined to the Programme by amendment of the attached Annex to this Agreement as provided in Article $10(\mathrm{c})$ hereto.

Aricle?

\section{THE EXECUTIVE COMMITTEE}

(a) Supervisory Control. Control of the Programme shall be vested in the Executive Committee constituted under this Article.

(b) Membership. The Executive Committee shall consist of one member designated by each Contracting Party: each Contracting Party shall also designate an alternate member to serve on the Executive Committee in the event that its designated member is unable to do so.

(c) Responsibilities. The Executive Committee shall:

(1). Adopt for each year, acting by unanimity, the Programme of Work for the Tasks of the attached Annex. together with an indicative programme of work for the following two years: the Executive Committee may, as 
required. make adjustments within the framework of the Programme of Work;

(2) Make such rules and regulations as may be required for the sound management of the Tasks:

(3) Carry out the other functions conferred upon it by this Agreement and the Annex hereto; and

(4) Consider any matters submitted to it by the Operating Agent or by any Contracting Party.

(d) Procedure. The Executive Committee shall carry out its responsibilities in accordance with the following procedures:

(1) The Executive Committee shall each year elect a Chairman and one or more Vice-Chairmen:

(2) The Executive Committee may establish such subsidiary bodies and rules of procedure as are required for its proper tunctioning. A representative of the Agency may artend meetings of the Executive Committee and its subsidiary bodies in an advisory capacity:

(3). The Executive Committee shall meet in regular session twice each year: a special meeting shall be convened upon the request of any Contracting Party which can demonstrate the need therefor:

(4) Meetings of the Executive Committee shall be held at such time and in such office or offices as may be designated by the Committee;

(5) At least twenty-eight days betore each meeting of the Executive Committee, notice of the time. place and purpose of the meeting shall be given to each Contracting Party and to other persons or entities entitled to attend the meeting; notice need not be given to any person or entity otherwise entitled thereto if notice is waived betore or after the meeting:

(6) The quorum for the transaction of business in meetings of the Executive Committee shall be one-hulf of the members plus one (less any resulting (iraction).

Voting.

(1) Where this Agreement requires the Executive Committee to act by unanimity. this shall require the agreement of each member or alternate member present and voting at the meeting at which the decision is taken. The Executive Committee shall adopt decisions and recommendations, for which no express voting provision is made in this Agreement, by majority vote of the members or alternate members present and voting; 
(2) With the agreement of each Contracting Party a decision or recommendation may be made by telex or cable without the necessity for calling a meeting. The Chairman of the Executive Committee shall have the responsibility of ensuring that all Contracting Patties are intormed of each decision or recommendation made pursuant to this paragraph.

(f) Reports. The Executive Committee shall. at least annually. provide the Agency with periodic reports on the progress of the Programme.

Aricle 3

THE OPERATING AGENT

(a) Desighation. An Operating Agent is designated in the Annex hereto.

(b) Scope of Authority to Act on Behalf of Contracting Parties. Subject to the provisions of Article 6 hereot. the Operating Agent shall pertorm all legal acts required to carry out its functions as detined in the tnnex hereto.

(c). Replacement. A Contracting Party may. with the consent of the Executive Committee. acting by unanimity. designate another entity as Operacing tigent in place of the Contracting Party or other Operating Agent designated by it. The adoption of any consequential amendments to this Ayrement and the tnnex hereto as well as the arrangements for transter of the Operating Agent's responsibilities shall require a decision of the Executive Committee. acting by uninimity.

(d) Resignation. The Operating Agent shall have the right to resign at any time. by giving six months written notice to that effect to the Executive Committee. provided that:

(1) A Contracting Party. or enticy designated by a Contracting Party. is at such time willing to assume the duties and obligations of the Operating Agent and so notities the Executive Committee and the ocher Contracting Parties to that effect. in writing. noc less than three months in advance of the effective date of such resignation; and

(2) Such Contracting Party or entity is approved by the Executive Committee, acting by unanimity. 


\section{Article 4 \\ ADMINISTRATION AND STAFF}

(a) Administration of Tasks. The Operating Agent shall be responsible to the Executive Committee for implementing its responsibilities in accordance with this Agreement, the Annex hereto and the decisions of the Executive Committee.

(b) Information and Reports. The Operating Agent shall furnish to the Executive Committee such information concerning the Annex hereto as the Committee may request and shall each year submit. not later than two months after the end of the financial year, a report on the status of the Annex hereto.

(c) Staff. It shall be the responsibility of the Operating Agent to retain such staff as may be required to carry out its responsibilities in accordance with rules determined by the Executive Committee. The Operating Agent may also, as required. utilise the services of personnel employed by other Contracting Parties (or organisations or other entities designated by Contracting Parties) and made available to the Operating Agent by secondment or otherwise. subject to arrangements to be agreed between the Contracting Party and the employer of such personnel.

Article 5

FINANCE

(a)

Research Costs.

(1) Each Contracting Party shall be responsible tor providing the financial resources necessary to carry out its research responsibilities under the Annex hereto. The Contracting Parties minimum levels of expenditure under the Programme shall be as follows:

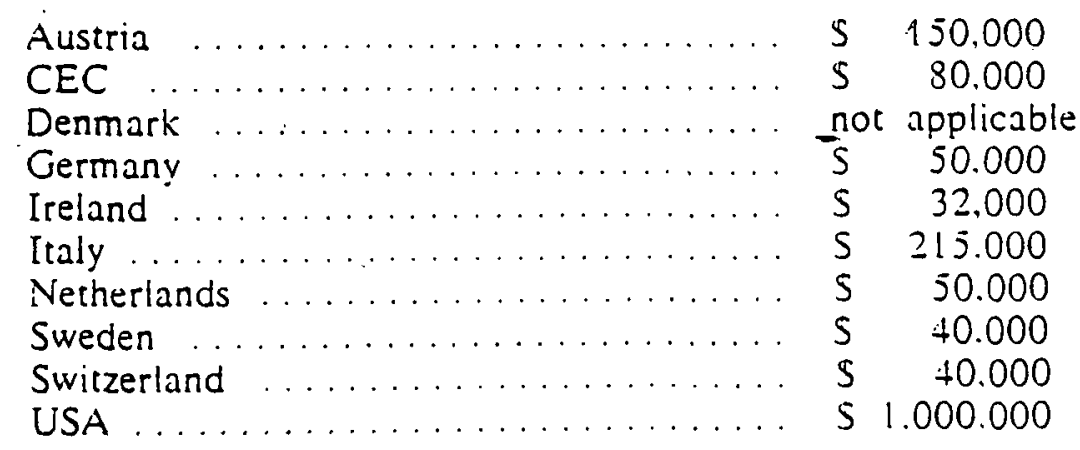


(2) The Executive Committee. acting by unanimity, shall adjust the tigures referred to in this paragraph at half-yearly intervals to take account of changing price levels in the country of each Contracting Party to ensure that the necessary real resources will continue to be available to conduct the work called for. If significant changes in such price levels occur. the Executive Committee. acting by unanimity. shall consider whether to adjust the Programme of Work to the available funds:

(3) Alter the initial three-year period and any succeeding three-year period. the Executive Committee shall. acting by unanimity. agree upon the levels of expenditure referred to in sub-paragraph (1) above for each succeeding three-year period.

(b) Other Costs. Each Contracting Party shall also bear all other costs it incurs in carrying out this Agreement. including the costs of formulating or transmitting reports and of reimbursing its emplovees for travel and ocher per diem expenses incurred in connection with work carried out on the respective Tasks.

(c) Financial Statement. 'Not later than three months aime the close of each financial year each Contracting Party shall submit to the Executive Committee a detailed financial statement concerning expenditure for the Tash during the financial year. Each Contracting Party shall make available such additional financial intormation un expenditure for the Task as the Executive Commictee may reasonably request in order to ensure that each Task is being carried out in accordance with this Agreement.

Article 6

INFORMATION AND INTELLECTUAL PROPERTY

(a) Executive Commirtee's Powers. The publication. distribution. handling. protection and ownership of intormation and intellectual property arising irom acrivities conducted under this Agreemenc shall be determined by the Executive Committee, acting by unanimity. in conformity with this Airreement.

(b) Right to Publish. Subject only to patents and copyright restrictions ot this Agreement. the Contracting Parties shall have the right to publish all information provided to or arising irom the Programme except proprietary intormation. but they shall not publish it with a view to profit except as the Executive Committee. acting by unanimity. may agree or provide by rule. All that intormation shall be available without charge to the Contracting Parties.

(c) Proprietary Intormation. The Contracting Parties shall take all necessary measures in accordance, with this Article. the laws of their respective countries and international law to protect proprietary intormation. For the purposes of this Agreement. proprietary information shall mean intormation of a contidential nature such as trade secrets and know-how (for example. computer programmes. design procedures and 
techniques. chemical composition of materia!s. or manufacturing methods. processes, or treatments) which is appropriately marked. provided such intormation:

(1) Is not generally known or publicly available from other sources:

(2) Has not previously been made available by the owner to others without obligation concerning its confidentiality; and

(3) Is not already in the possession of the recipient Contracting Party without obligation concerning its confidentiality.

It shall be the responsibility of each Contracting Party supplying proprietary information to identify the information as such and to ensure that it is appropriately marked.

(d) Production of Relevant Information by Governments. The Operating Agent should encourage the governments of all Agency Participating Countries to make available or to identify to the Operating Agent all published or otherwise treeiv available intormation known to them that is relevant to the Tasks in the attached Annex. The Contracting Parties should notity the Operating Agent of all pre-existing information. and information developed independently of the Tasks known to them which is relevant to the Tasks and which can be made available to the Tasks without contractual or legal limitations.

(e) Reports on Programme Work. Reports containing arising information and pre-existing information necessary for and used in each Task. including proprietary information. shall be provided to each Contracting Party by the Contracting Party performing the Task. It shall be the responsibility of each Contracting Party to identify intormation which qualifies as proprietary information under this Article and ensure that it is appropriately marked. The Operating Agent shall provide summary reports of work performed under the Annex hereto and the results thereof (arising intormation), other than proprietary information. to the Executive Committee.

(f) License of Proprietary Information. Each Cuntracting Party agrees to license all pre-existing proprietary intormation necessary for and used in its Task which it owns or controls and all arising proprietary intormation to the Contracting Parties. their governments. and the nationals of their respective countries designated by them:

(1) Royalty-free tor use in their country only; and

(2) On reasonable terms and conditions for use in all other countries.

Each Contracting Party agrees to license all such arising proprietary information to all Agency Participating Councries on reasonable terms and conditions for use in their own country in order to meet their energy needs.

(g) License of Patents Needed for Task. Patents solely owned ur controlled by a Contracting Party which are needed for use in each Task shall be licensed to the Task Contracting Party tor use in the Task only at no cost to such Contracting Party. If such patents are partially owned or controlled by a Concracting Party, then efforts shall 
be made by the Contracting Party to reduce or eliminate as possible the benefit that might accrue to it.

(h) Arising linventions. Inventions made or conceived in the course of or under any Task (arising inventions) shall be owned in all countries by the inventing Contracting Party. Intormation regarding inventions on which patent protection is to be obtained by the Contracting Party shall not be published or publicly disclosed by the other Contracting Parties until a patent application has been filed. provided. however. that this restriction on publication or disclosure shall not extend beyond six months from the diate of receipt of such information. It shall be the responsibility of the inventing Contracting Party to appropriately mark reports which disclose inventions that hatie not been appropriately protected by the filing of a patent applicition.

(i) License of Inventions. Each Contracting Party agrees to license all preexisting inventions covered by patents owned or controlled by it which are necessary for practising the results of its Task and which have been utilised in the Task. and all arising inventions to the Contracting Parties. their guvernments and the nationals ot their respective countries designated by them:

(1) Royalty-tree for use in their country only: and

(2) On reasonable terms and conditions for use in all other countries.

Each Contracting Party agrees to license all such arising inventions to all Agency Participating Countries on redsonable terms and conditions for use in their own country in order 10 meet their energy needs.

(i) Copyright. The Operating Agent or cach Coneracting Party tor its own Task results may take appropriate measures necessary to protect copyrightable material generated under any Tisk. Copyrights obtained shall be the property of that Contracting Party or the Operating Agent, provided. however. that Contricting Parties maly reproduce and distribute such material, but shall not publish it with a view to profit.

(k) Inentors and futhors. Each Contracting Party will. without prejudice to any rights of inventors or authors under its national laws. takc all necessary steps to provide the co-operation trom its authors and inventors required to carry out the provisions of this Article. Each Contracting Party will assume the responsibility to paly alvards or compensation required to be paid to its amplovees according to the latvs of its counery.

(1) Determination "! "Vuriomal". The Contracting Parties may establish gruidelines to determine what constitutes a "national" of a Contrateting Party. Disputes that cannot be scteled by the Contracting Partics shall be setted under Article $S(d)$ of this Implementing Agreement.

\section{Article 7}

\section{LEGAL RESPONSIBILITY}

No Contracting Party shall be liable to compensite or contribute to any other Contracting Party tor any loss or damage sutfered in the course of carrying out the Programme. 
Article 8

\section{LEGISLATIVE PROVISIONS}

(a) Accomplishment of Formalities. Each Contracting Party shall. within the framework of applicable legislation. use its best endeavours to facilitate the accomplishment of formalities involived in the movement of persons. the importation of materials and equipment and the transter of currency which shall be required to conduct any Task or Tasks in which it is engaged.

(b) Applicable Laws. In carrying out this Agreement and the various Tasks in the Annex hereto. the Contracting Parties shall be subject to the appropriation of funds by the appropriate governmental authority. where necessary. and to the constitution. laws and regulations applicable to the respective Concracting Parties. including. but not limited to, laws establishing prohibitions upon the puyment of commissions. percentages, brokerage or contingent fees to persons retained to solicit governmental contracts and upon any share of such contracts accruing to government officials.

(c) Decisions of Agency Governing Board. The Contracting Parties shall take account. as appropriate. of the Guiding Principles for Co-operation in the Field of Energy Research and Development. and any modification thereof. as well as other derisions of the Governing Board of the Agency in that tield. The termination of the Guiding $i$ rinciptes shall not affect this Agreement. which shall remain in torce in accordance with the terms hereof.

(d) Settlement of Disputes. Any dispute umong the Contracting Parties cuilcerning the interpretation or the application of this Agreement which is not settled by negotiution or orher agreed mode of settlement. shall be referred to a tribunal of three arbitrators to be chosen by the Contracting Parties concerned who shall also choose the Chairman of the tribunal. Should the Contracting Parties concerned tail to agree upon the composition of the tribunal or the selection of its Chairman. the President of the International Court of Justice shill. at the request of any of the Contracting Parties concerned. exercise those responsibilities. The tribunal shall decide any such dispute by reterence to the teims of this Agreement and any applicable laws and regulations. and its decision on question of tact shall be finat and binding on the Contracting Parties.

Article 9

ADMISSION AND WITHDRAWAL OF CONTRACTING PARTIES

(a) Admission of iVew Contracting Parties: Agency Countries. Úpon the invitation of the Executive Committee. acting by unanimity. admission to the Agreement shall be open to the government of any Agency Participating Country (or a national agency. public organisation. private corporation. company or other entity designated by such government), which signs or accedes to this Agreement. accepts the rights and obligations of a 
Contracting Party and agrees to carry our at least one Task defined in the Annex hereto. Such admission of a Contracting Party shall become effective upon the signature of this Agreement by the new Contracting Party or its accession thereto and the adoption of any consequential amendments thereto.

(b) Admission of $V$ ew Contracting Parties: Other OECD Countries. The government of any Member of the Organisation for Economic Co-operation and Development which does not participate in the Agency may. on the proposal of the Executive Commitree. acting by unanimity. be invited by the Governing Board of the Agency to become a Contracting Party to this Agreement (or to designate a national agency. public urganisation. private corporation. company. or other entity to do so). under the conditions stated in paragraph (a) above.

(c) Participation by the European? Communities. The European Communities may participate in this Agreement in accordance with arrangements to be made by the Executive Committee. actin@ by unanimity.

(d) Contributions. The Executive Committe may require. as a condition to admission to participation. that the new Contracting Party accept obligations which are designed to compensate the Contracting Parties as appropriate for their prior contribucions to the Programme.

(e) Replacement of Contracting Parties. With the agreement of the Executive Committee. acting by unanimity. and upon the request of a government. a Contracting Party designated by that government mily be replaced by another party. In the event of such replacement, the replacement party shall assume the rights and obligations of a Contracting Party as provided in paragraph (a) above and in accurdance with the procedure provided therein.

(f) Withdrawal. Any Contracting Party may withdraw trom this Agreement either with the agreement of the Executive Cummittee. acting by unanimity. or by giving twelve months written Votice of Withdrawal to the Executive Director of the Agency. such Votice to be given not less than two years after the date hereot. The withurawal of a Contracting Party under this paragraph shall not affect the rights and ubligations of the ocher Contracting Parties.

(g) Change of Status of Comtracting Party. A Cuntracting Party other than a government or an international organisation shall torthwith notify the Executive Committee of any significant change in its status or ownership. or of its becoming bankrupt or entering into liquidation. The Executive Committee shall determine whether any such change in status of a Contracting Party significantly affects the interests of the other Contracting Parties; if the Executive Committee so determines. then. unless the Executive Committee. acting upon the unanimous decision of the other Contracting Parties. urherwise agrees:

(1) That Contracting Party shall be deemed to have wichdrawn trom the Agreement under pardgraph (i) above on a date to be tixed by the Executive Committee: and

(2) The Executive Committee shall invite the government which designated that Contracting Party to designite. within a period of three months of the withdrawal of that Contracting Party. a different entity to become 
a Contracting Party: it approved by the Executive Committee. acting by unanimity, such entity shall become il Contracting Party with effect from the date on which it signs or accedes to this Agreement.

(h) Failure to Fulfil Contractual Obligations. Any Contracting Party which fails to fulfil its obligations under this Agreement within sixty days after its receipt of notice specifying the nature of such failure and invoking this paragraph, may be deemed by the Executive Committee. acting by unanimity, to have withdrawn from this Agreement.

\section{Article 10}

\section{FINAL PROVISIONS}

(a) Term of Agreement. This Agreement shall remain in force for an initial period of three years from the date hereof. and shall continue in force thereafter unless and until the Executive Committee, acting by unanimity, decides on its termination.

(b) Legal Relationship of Contracting Parties. Nothing in this Agreement shall be regarded as constituting a partnership between dny of the Contracting Parties.

(c) Amendment. This Agreement and the Annex hereto may be amended at any time by the Executive Committee. acting by unanimity. Such amendments shall come into force in a manner determined by the Executive Committee. acting by unanimity.

(d) Deposit. The original of this Agreement shall be deposited with the Executive Director of the Agency and a certified copy thereot shall be furnished to each Contracting Party. A copy of this Agreement shall be turnished to each Agency Participating Country. to each Vember country of the Organisation for Economic Co-speration and Deveiopment and to the European Communities.

Done in Paris, this 16 th day of March. 1977. 
For the Republic of Austria:

For the MINISTRY OF Trade aNo INDLSTRY

for and on behalf of the Government of Denmark:

For the Ker.veorschtivgsailatge Jülich G.m.b.H. (designated by the Government of Germany):

For the Consiglio Nazionale DELLE RICERCHE (designated by the Government of Italy):

For the Government of Ireland:

For the SWEDISH COUNCIL FOR BUILDING RESE.ARCH !designated by the Government of Sweden):

For the Office fédéral de la Science ET DE LA RECHERCHE DU DÉParteiment FÉdéral de L'INTÉrIeUR for and on behalf of the Government of Switzerland:

For the United States Evergy Research and Developinent Administration for and on behalf of the Government of the United States of America: 


\section{AVIVEX \\ HEAT PUMP SYSTEMS WITH THERMAL STORAGE}

\section{Objectives}

The objectives of this Programme are to conduct theoretical and experimental development programmes in the area of heat pump systems. and to provide a central collection. collation and distribution centre for the exchange of information in the field of heat pump systems and for the preparation and execution of research and development in that field.

This Programme will be limited to heat pump systems with thermal storage for the generation of heat for non-industrial purposes. such as domestic space and water hearing using the compression cycle. and will thus exclude the absorption cycle.

\section{Means}

Each Concracting Party will carry ouc the specitic Task or Taskis indicated for the Contracting Party and defined in paragraph 3 of this Annex. relating to the demonstration of a heat pump sustem with thermal storidre.

The Contracting Parties will also collect and exchange data recirding development programmes in the heat pump tield including work being undertakion in the research. testing. design. evaluation. production and application of heal pump systems. including directly related hardivare.

\section{Responsihilities of Contractin!: Partices}

Task 11) AUSTRIA: "Minergy.House $V_{0}$. 1" at Schönau nedr Viennal utilising an air-to-tvater heat pump for spalce and residential water heating. Oucdoor air is used ats at heat source. This heat is transferred to and extracicd from the storing subsoil by means of an ateratod gravel bed.

(2) CEC: $\quad$ A project providing operational experience with electrically driven heat pump systems combined with heat storage.

(3). DeNMARK: Evaluation of the projects contributed by the other Participating Cuuntries.

Preparation and publication ut reports lin co-operation with the Operuting Agent).

(4) GervanY: Heat pump system with wateríce latent hat storage for a home on the Rhine near Karlsrube: and a project using an earth-heating pump with switching capatity to external air. 
(5) - IRELAND:

(6) ITALY:

(8) SWEDEN:

(9) SWITZERLAND:

(10) LSA:
Air source heat pump system with short-term water-storage units to meet possible space and water heating requirements of a typical domestic unit.

Demonstration ot a heat pump system operated by an independent poiver generator (diesel engine). Design and construction of prototype organic fluid turbine prime mover. In both cases the heat pump systems are supplemented by heat recovered from the power generator.

(7) Netherlaivos: Thermodynamic studies of different heat pump systems; experiments involving process control instrumented heat pumps in inhabited residential houses: and technical and economic reasibility studies.

At least one project with a heat pump in connection with a thermal storitge system within the national solar energy programme. National demonstration projects with heat pumps for residential houses using different heat sources.

Heat pump application with warm water storage using the ground as heall sualce for spacs hedting by Berner Krattiverke $A G$.

A project designed to demonstrute the capability of the Annual Cycle Energy System (ACES) at Oak Ridge Niationa! Laboratory. Oak Ridgre. Tennessece. The principal component of this systen is an insulated tank of water which serves as at thermal storage bin. In winter. heat is obtained by a healt pump. which also curns the water in the bin into ice. over a period of months. In summer. the chilled water is used to provide alir conditioning without the operation of the heat pump compressur.

4. Operating. Agent

Republic of Austria.

\section{Specific Responsibilities of the Operating tegent}

(a) Within ninety (90) days of the entry into torce of this Annex. the Operating Agent will. after consulting edch Cuncracting Party. prepare and submit to the Executive Committee tor its approval a detailed Programme of Work on the torm and the scope of the data and reports required trom each Contracting Party regarding its project tor calendar year 1977. By Ist December of each vear thereatter the Operating Agent shall submit a Programme of Wurk for the following year. The Programmes of Work will be adopted by the Executive Committee. acting by unanimity.

(b) The Operating Agent will ensure that a mechanism exists for Contracting Parties to contact the originators of work undertaken for the Programme. 
(c) The Operating Agent may plan and propose to the Executive Committee the holding of meetings of experts on heat pump systems with thermal storage to bring about further collaboration in this field.

\section{Funding}

Funding shall be borne by the Contracting Parties in accordance with Article $5(a)$ (1) of the Agreement. 
INTERNATIONAL ENERGY AGENCY

\section{IMPLEMENTING AGREEMENT FOR A PROGRAMIME OF RESEARCH AND DEVELOPMENT ON ENERGY CONSERVATION IN HEAT TRANSFER AND HEAT EXCHANGERS}


THIS PAGE

\section{WAS INTENTIONALLY LEFT BLANK}




\section{IMPLEMENTING AGREEMENT FOR A PROGRAMME OF RESEARCH AND DEVELOPMENT ON ENERGY CONSERVATION IN HEAT TRANSFER AND HEAT EXCHANGERS}

TABLE OF CONTENTS

PREAMBLE

Articte I

OBSECTIVES

j

Aricile :-

IDENTIFICATION ANO INITIATION OF TASkS

Aricle ;

Tia Executive Comimitee

Arricle +

THE OPERATING AGENTS

Arricle 5

ADMINISTRATION AND STAl:F

Aricte 6 
Arriele 7

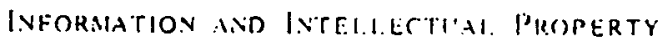

Arricle s

LEGAL RESPONSIBILITY a.NO INSURANTE

Aricle 9

Legislative Provisions

Artirle 10

ADMISSION AVD WITHORAWAL UH CUNIRACTING PARTIFS

Hricle 11

Final Provisions

\section{ANNEXES}

Annex I

Extended Surface Heat Transfer

Arnex $/ 1$

The Optimal Design of Heat Exchanger Networks

Anner $\mid I I$

Heat Exchanger Tube Vibration 


\section{IMPLEMENTING AGREEMENT FOR A PROGRAMME OF RESEARCH AND DEVELOPMENT ON ENERGY CONSERVATION IN HEAT TRANSFER AND HEAT EXCHANGERS}

The Contracting Parties

Covsurkive; that the Contracting Partics, being either governments br international organisations or parties designaled by their respectic governments pursuant to

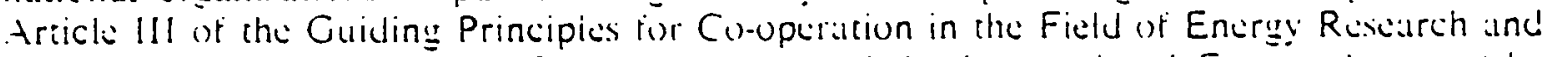
Development adoped by the Gowerning Bodrd ot the International Energy Agency dethe "Agensy") on 28ch July. 1975. wish to take part in the cstablishment and opcration of is Programme of Research and Development on Energy Conservation in Heat Transter and Heat Exchangers ("the Proyramme") as provided in this Agreement:

Constl)epase that the Contracting Parties which are governments and the govern-

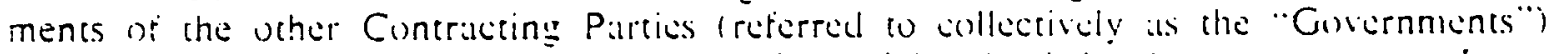
participale in the Agency and have dagreed in Article -1 of the Agrement on an Internationdi Energe Program (the "l.E.P. Agreement") (o undertaki national programmes in the areas set out in Article $\$ 2$ of the I.E.P. Agresment. including rescarch and deselopment on encrg: conservation in which field the Programme will be carried out:

CONSIDERING that in the Governing Bourd of the Agency on 16th . March. 1977 the Gurernments approved the Programme as a special activity under trtick 65 wi the I.E.P. turrement:

ConsIDERING; that the Agency has recugnised the establishment vi the Programme as an important component of incernational a)-(o)peration in the tield of energy consirtition research and development:

HAVE AGREED as follows:

Article 1

\section{OBJECTIVES}

(a) Scope of atcivity. The Progranme to be carricd out by the Coneracting Parties within the framework of this Agrement shall consist of co-operatice rescarch. development. demonstrations and exchanges of information regarding energy consicruation in heat transter and heat exchangers. 
(h) Wethed of Implementation. The Contracting Partics shall implement the Programme by undertaking une or more tasks (the "Task" or "Tusks") each of which will be upen lo participation by two or more Contracting Partics as provided in Articke 2 hercot. The Contracting Partics which participalc in at parricular Task alre. for the purposes of that Tast. referred os in this Agreement ds "Participants".

(c) Tusk Conerdination and Co-operation. The Contracting Partics shall couperate in co-ordinating the work of the various Tatsts and shall endeilvour. on the bas of an appropriate sharing of burdens and benclits. (1) encourige cov-operation among Participants engaged in the burious Tasks with the objective of alvancing the research and development activities of all Contracting Parties in the field of energy conservation in heat transter and heat exchangers.

Article ?

\section{IDENTIFICATION AND INITIATION OF TASKS}

(a) Identification. The Tastis undertaken by Participants are identitied in the Annexes to this Agreement. At the time of signing this Agreenknt. salch Concracting Party shall confirm its intention to participate in une or more Tusks by giving the Executive Director of the Agency a Notice of Participation in the relevant tnnex or tnnexes and the Operating Agent for each Task shall give the Executive Director of the Agency a Votice of Acceptance of the Task Annex. Thereulicr. auch Tush shall be carricd out in accordance with the procedures set forth in Articles 21011 hercot. unless ocherwise spociricully provided in the applicable Annex.

(h) Iniriarion of Addiriomal Tasks. Additional Taskis may be iniciatcal by any Contracting Party according to the following procedure:

(1) A Contracting Party wishing to initiate a new Task shall present (1) one or more Contracting Parties for approval a draft tnnex. similar in form to the Annexes attached hereto. containin: a description of the scope of work and conditions of the Tash proposed (1) be pertormed:

(2) Whenever two or more Contracting Parties agree to undertake at new Task. they shall submit the uraft Annex for approval by the Executive Committee pursuant to Article 3 (e) (2) horcot: the approved dralt Annex shall become part of this forecement: Vurfice of Participation in the Task by Contracting Parties and acceptance by the Operating Agent whall be communicated (o) the Exccutive Director in the manner provided in paragraph (a) above:

(3) In carrying out the various Tasks. Participants shall co-urdinate their activities in order to aroid duplication of activities.

(c) Application of Task fmexes. Eilch Annex shall be binding only upon the Participants therein and upon the Operating Agent for that Task. and shall not affect the rights or obligations of other Contracting Parties. 


\section{Article 3}

\section{THE EXECUTIVE COMMITTEE}

(a) Supervisory Control. Control of the Programme shall be vested in the Executive Committee constituted under this Article.

(b) Membership. The Executive Committee shall consist of one member desitnated by each Contracting Party; each Contracting Party shall also designate an alcernate member to serve on the Executive Committee in the event that its designated member is unable to do so.

(c) Responsibilities. The Executive Committee shall:

(1) Adopr for each year. acting by ununimity, the Programme of Work. and Budget if foreseen. tor each Task, cogether with an indicative programme of work and budget for the following (wo yedrs: the Executive Committee may, as required. make adjustments within the tramework of the Programme of Work and Budget:

(2) Make such rules and regulations as may be required for the snund management of the Tasks. including tinancial rules as provided in Article $h$ hereof:

(3) Carry out the ocher functions conferred upon it by this Agre:ment and the Annexes hereto: and

(4) Consider any matters submitted to it by any of the Operuiting Agents or by any Contracting Party.

(d) Procedure. The Excicutive Committee shall curry out its responsibilitices in accordance with the tollowing procedures:

(1) The Executive Committee shall each year elect a Chairman and wne or more Vice-Chairmen:

(2) The Executive Committee may escablish such subsidiary hodici, and rules of procedure as are required for its proper functionin:. A refresentutive of the Agency and a representative of each Operating Agent lir its capacity as such) may attend meetings of the Executive i un!mitle and its subsidiary bodies in an advisory capacity:

(3) The Executive Committee shall meet in rewalar session iwici rach year: a special meeting shall be convertied upon the request of any contrituing Party which can demonstrite the need therefor:

(4) Meetings of the Executive Committee shall be held at sach time and in such office or offices as may be designated by the Cummitie: 
(5) At least twenty-eight days before each meeting of the Executive Committee. notice of the time. place and purpose of the meeting shall be given to each Coneracting Party and to other persons or entities entitled to attend the meeting: nutice need not be given to any person or entity otherwise entitled thercto $i \hat{i}$ notice is waved betore or atter tho meeting;

16) The quorum for the transaction of business in mcetings of the Executive Committee shall be one-hallf of the memoers plus une lless any resulting fraction) provided that any action relating (o) : particular Task shall require a quorum as atoresaid of members or alternate members designated by the Participants in that Task.

(1) When the Executive Committe alopts a decision or recommenuation for or concerning a particular Tush. the Executive Committee shall act:

(i) When unanimity is required under this Agrement: by aprecment of those members or alternate members which were designaled by the Participants in that Tusk and which are present and voting:

(ii) When no express boring provision is mids in this Agrowment: by majority vote of those members or alternate nembers which were designated by the Patricipants in that Task and shich are proxine and voting;

(2) In all other wases in which this terrentent cxpossly reyuires the Executive Commictee to aci by unanimity. this shatil reyuire the atereement of each member or alternate member present and woting. and in rispect of all other decisions and reconmendutions for which no express voring:provision is matde in this Agreentent. the Exicutio Commitite shall act by a majority vote of the members or alcernate members present and voting. If a government has designated more dhan one Contracting Party to this Agreement. chose Contracting Partics may cast unly onc vote under this pardigrapin:

(3) The decisions and recommendations reterred (o in paragraphs (1) and (2) above may. with the agreement af each member or allernate member entitled to act thereon. be made by muil. elex or cable without the necessity for calling a meting. Such action shal be taken by unanimity or majority of such members as in a meering. The Chairman of the Executive Committee shall ensure that all mombers are intormed of each decision or resommendation made pursuanc (1) this paragrapin.

(f) Reports. The Executive Committce shall, at kist annually provide the Agency with periodic reports on the progress of the Programme. 


\section{Article 4 \\ THE OPERATING AGENTS}

(a) Designation. Participants shall designale in the relevant Annex an Operating Agent for auch Tistk. Reterences in this Agrcement to the Operating Agent shall apply to adch Operating Agent in respect of the Tist for which it is responsible.

ih) Scope of Authority of Act on Behalf of Participants. Subject to the provisions of the applicable Annex:

(1) All legal acts required to carry out each Task shall be performed on behalf ot the Participants by the Operating Agent for the Task:

(2) The Operating Agent shall hold. for the benefit of the Participants. the legal title to all property rights which may accrue to or be acquired for the Tusk.

The Operating Agent shall operate the Tas' under its supervision and responsibility. subject to this Agreement. in uccordance with the law of the country of the Operating. Agent.

(c) Reimbursements of Costs. The Excoutive Commitec may provide that expenses and costs incurred by an Operating Agent in acting as such pursuant to this Agreement shall be reimbursed to the Operating Agent from funds made available by the Participants pursuant to Article 6 hereot.

(d) Replacement. Should the Executive Committes wish to replace an Operating Agent with another governmient or entity. the Exccutive Committe maly. acting by unanimity and with the consiont of such grovernment or entity. replace the initial Operating Agent. References in this Agrcement to the "Operatin" Agent" shatl include any gerernment or entity appointed to replace the origina! Operatin” Agent under this parayraph.

(e) Resignation. An Operating Agent shall have the right (u) resign all any time. by giving six months written notice to that effect to the Executive Committed. provided that:

(1) A Participant. or encicy Jesignaled by a Participant. is att such timle willing to assume the duties and obligations of the Operating Agent and so notifies the Executive Committee and the other Participants to that effect. in writing. not less than three months in advance of the effective date of such resignation; and

(2) Such Participant or entity is approved by the Executive Committee. acting by unanimity.

(if) Accounting. An Operating Agent which is replaced or which resigns as Operating Agent shall provide the Executive Committee with an accounting of any monies and other assets which it may have collected or acquired for the Task in the course of carrying out its responsibilities as Operating Agent. 
(g) Transfer of Rights. In the event that another Operating Agent is appointed under paragraph (d) or (e) above, the Operating Agent shall transfer to such replacement Operating Agent any property rights which it may hold on behalf oi the Task.

(h) Information and Reports. Each Operating Agent shall furnish to the Executive Committee such information concerning the Task as the Committee may request and shall each year submit, not later than two months after the end of the financial year, a report on the status of the Task.

\section{Article 5}

\section{ADMINISTRATION AND STAFF}

(a) Administration of Tasks. Each Operating Agent shall be responsible to the Executive Committee for implementing its designated Task in accordance with this Agreement, the applicable Task Annex, and the decisions of the Executive Committee.

(b) Staff. It shail be the responsibility of the Operating Agent to retain such staff as may be required to carry out its designated Task in accordance with rules determined by the Executive Committee. The Operating Agent may also. as required. utilise the services of personnel employed by other Participants (or organisations or other entities designated by Contracting Parties) and made available to the Operating Agent by secondment or otherwise. Such personnel shall be remunerated by their respective employers and shall. except as provided in this Article. be subject to their employers conditions of service. The Contracting Parties shall be entitled to claim the appropriate cost of such remuneration or to receive an appropriate credit for such cost as part of the Budget of the Task, in accordance with Article $6(f)(6)$ hereot.

Article 6

\section{FINANCE}

(a) Individual Obligations. Each Contracting Party shall bear the costs it incurs in carrying out this Agreement. including the costs of formulating or transmitting reports and of reimbursing its employees for travel and ocher per diem expenses incurred in connection with work carried out on the respective Tasks. unless provision is made for such costs to be reimbursed irom common funds as provided in paragraph $(g$ ) betow.

(b) Common Financial Obligations. Participants wishing to share the costs of a particular Task shall agree in the appropriate Task Annex to do so. The apportionment of contributions to such costs (whether in the form of cash. services rendered. intellectual property or the supply of materials) and the use of such contributions shall be governed by the regulations and desisions made pursuant to this Article by the Executive Committee. 
(c) Financial Rules, Expenditure. The Executive Committee, acting by unanimity, may make such regulations as are required for the sound financial managemenc of each Task including, where necessary:

(1) Establishment of budgetary and procurement procedures to be used by the Operating Agent in making payments from any common lunds which may be maintained by Participants for the account of the Task or in making contracts on behalf of the Participants:

(2) Establishment of minimum levels of expenditure for which Executive Committee approval shall be required. including expendicure involving payment of monies to the Operating Agent for vther than routine salary and administrative expenses previously approved by the Executivi Committee in the budget process.

In the expenditure of common funds. the Operating Agrent shall take into account the necessity of ensuring a fidir distribution of such expendicure in the Participants countries. where this is fully compatible with the most efficient technical and tinancial management of the Task.

(a) Crediting of lncome to Budeet. Any income which accrues from a Task shall be credited to the Budget of that Task.

(e) Accounting. The system of accounts emploved by the Operating tyent shall be in accordance with accounting principles gencrally accepted in the councry of the Operating Agent and consistently applied.

(i) Programme of Work and Buderet. Keeping af ficommes. Should Participants agree to maintain common funds for the pibment of obligations under a Programme of Work and Budget of the Tusk. accounts shull be muintained as folluws unless ocherwise decided by the Executive Committee, acting by unanimity:

(1) The financial year of the Task shall correspond to the tinancial year of the Operating Agent;

(2) The Operating Agent shull each year prepare and submit w the Executive Committee for approval a draft Programme of Work and Budget. cogether with an indicacive programme of work and budget for the following two years. noc later thun three munths betore the beginning of each tinancial year:

(3) The Operating Agent shall maintain complete. separde tinancial records which shall clearly accounc for all funds and property coming into the custody or possession of the Operating Agrent in connec' in with the Task;

(4) Not later than three months after the close of each iniuciui year the Operating Agent shall submit to auditors selected by the Executive Committee tor audit the annual accounts maintained for the Task: upon completion of the annual audit. the Operating Agent shall present the 
accounts together with the auditors' report to the Executive Committee for approval:

(5) All books of account and records maintained by thic Operating Agent shall be preserved for at least three years firom the date of terminution of the Task;

(6) Where provided in the relevant Annex. a Participant supplying services. materials or intellectual property to the Task shall be entitled to a credit. determined by the Executive Committee. acting by unanimity. against its contribution tor to compensation. if the value of such services. materials or inteflectual property exceeds the amount of the Participant's contribution): such credits for services of staff shall be calculated on an agreed scale approved by the Executite Commictee and include all payroll-related costs.

(g) Contriburion to Common Famds. Should Participants auree to escablish common funds under the annual Programme of Work and Budget for a Tusk. any financial contributions due from Participants in a Tusk shall be paid to the Operating Agent in the currency of the country of the Operating Agent at such times and upon such other conditions as the Executive Committee. acting by unanimity. shall determine. pruvided however that:

(1) Contributions received by the Operating. Agent shall be used solely in accordance with the Programme of Work and Budget for ihe Tas'.:

(2). The Operating Agent shall be under no obligation to carry nut any work on the Task until contributions amounting to at least hitty per cent (in cash terms) of the total due at any one time have been received.

(h) Ancillary Services. Ancillary scrvices muy. as agroed between the Executive Committee and the Operating Agent, be provided by that Operating Agent fur the operation of a Task and the costs of such services. including overheads connected therewith. may be met from budgeted tunds of that Task.

(i) Taxes. The Operating Agent shall pav all taxcs and similar impositions (other than taxes on income) imposed by national or local governments and incurred by it in connection with a Task. as expenditure incurred in the operation of that Task under the Budget: the Operating Agent shall. however. endejvour to vbtain all possible exemptions from such taxes.

(i) Audit. Each Participunt shall have the right. at its sole cost. to iudit the accounts of any work in a Task for which common funds are maintained on the following terms:

(1) The Operating Agent shall provide the other Participints with an opportunity to participate in such audits on a cost-shared basis:

(2) Accounts and records relating to activities of the Operating Agent other than those conducted for the Task shall be excluded from such audit. 
but if the Participant concerned requires verification of charges to the Budget representing services rendered to the Task by the Operating Agent, it may at its own cost request and obtain an audit certificate in this respect from the auditors of the Operating Agent:

(3) Not more than one such audit shall be required in any financial year;

(4) Any such audit shall be carried out by not more than three representatives of the Participants.

Article 7

INFORMATION AND INTELLECTLAL PROPERTY

It is expected that for each Task agreed to pursuant to this Agreement. the applicable Annex will contain information and intellectual property provisions. The General Guidelines Concerning Intormation and Intellectual Property. approved by the Governing Board of the Agency on 21st November. 1975. shall be taken into account in developing such provisions.

Article 8

\section{LEGAL RESPONSIBILITY AND INSURANCE}

(a) Liahilitv of Operating Agent. The Operating Agent shall use all reasonable skill and care in carrying out its duties under this Agreement in accordance with all applicable laws and regulations. Except as otherwise provided in this Article. the cost of all damage to property, and all expenses associated with claims. actions and other costs arising from work undertaken with common funds for a Task shall be charged to the Budget of that Task; such costs and expenses arising from other work undertakion for a Task shall be charged to the Budget of that Task if the Task Annex so provides or the Executive Committee. acting by unanimity, so decides.

(b) Insurance. The Operating Agent shall propose to the Exccutive Committec all necessary liability. fire and other insurance. and shall carry such insurance is the Executive Committee may direct. The cost of obtaining and maintaining insurance shall be charged to the Budget of the Task.

(c) Indemnification of Contracting Partices. The Operating Agent shall be liable. in its capacity as such. to indemnify Participants against the cost of any damage to property and all legal liabilities. actions. claims, costs and expenses connected therewith to the extent that they: 
(1) Result from the failure of the Operating Agent to maintain such insurance as it may be required to muintain under parạ̣raph ( $h$ ) above: or

(2) Result from the gross negligence or wilful misconduct of any officers or employees of the Operiting Agent in carrying out their duties under this Agreement.

\section{Arricle 9}

\section{LEGISLATIVE PROVISIONS}

(a) Accomplishment of Formalities. Edch Participant shall request the appropriate authorities of its country (or its Member States in the case of an international organisation) to use their best endedvours. within the framework of applicable legislation. to facilitate the accomplishment of tormalities involved in the movement of persons, the importation of materials and equipment and the transfer of currency which shail be required to conduct the Task in which it is engaged.

(b) Applicahle Laws. In carrying out this Agrcement and its Annexus. the Contracting Parties shall be subject to the appropriation of funds by the appropriale governmental authority, where necessary. and to the constitution. laws and regulations applicable to the respective Contracting Parties. including. but not limited to. laws establishing prohibitions upon the payment of commissions. percentages, brokerage or contingent tees to persons retained to solicit governmental contracts and upon any share of such contracts accruing to governmental officials.

(c) Decisions of Agency Governing Board. Participants in the various Tasks shall take account, as appropriate, of the Guiding Principles for Co-operation in the Field of Energy Research and Development, and any modification thereot. as well as ocher decisions of the Goveming Board of the Agency in that field. The termination of the Guiding Principles shall not affect this Agreement. which shall remain in torce in accordance with the terms hereot.

(d)

Settlemeint of Disputes. Any dispute among the Cuntracting Parties concerming the interpretation or the application of this Agreement which is not setcled by negotiation or other agreed mode of settlement, shall be referred to a tribunal of three arbitrators to be chosen by the Contracting Parties concerned who shall also choose the Chairman of the tribunal. Should the Contracting Parties concerned iail to agree upon the composition of the tribunal or the selection of its Chairman. the President of the International Court of Justice shall. at the request of any of the Contracting Parties concerned, exercise those responsibilities. The tribunal shall decide any such dispute by reference to the terms of this Agreement and any applicable laws and regulations. and its decision on a question of lact shall be tinal and binding on the Contracting Parties. Operating Agents which are not Contracting Parties shall be regarded as Contracting Parties for the purpose of this paragraph. 
Article 10

\section{ADMISSION AND WITHDRAWAL OF CONTRACTING PARTIES}

(a) Admission of New Contracting Parties: Agency Countries. Upon the invitation of the Executive Committee, acting by unanimity, admission to this Agreement shall be open to the government of any Agency Participating Country lor a national agency, public organisation, private corporation. company or other entity designated by such government), which signs or accedes to this Agreement. accepts the rights and obligations of a Contracting Party, and is accepted for participation in at least one Task by the Participants in that Task. acting by unanimity. Such admission of a Contracting Party shall become effective upon the signature of this Agreement by the new Contracting Party or its accession thereto and its giving votice of Participacion in one or more Annexes and the adoption of any consequential amendments thereto.

(b) Admission of New Contracting Parties: Other OECD Countries. The government of any Member of the Organisation for Economic Co-operation and Development which does not participate in the Ayency may, on the proposal of the Executive Committee. acting by unanimity, be invited by the Governing Board of the Agency to become a Contracting Party to this Agreement for to designate a national agency. public organisation. private corporation. company or other entity to do sol. under the conditions stated in paragraph (a) above.

(c) Participation by the European Communitics. The European Cummunities may participate in this Agreement in accordance with arrangements to be made by the Executive Committee. acting by ununimity.

(d) Admission of New Participants in Tasks. Any Contracting Party muy. with the agreement of the Participants in a Task. acting by unanimity. become a Paricipant in that Task. Such participation shall become effective upon the Contracting Parly's givin: the Executive Director of the Agency a Votice of Participation in the appropriate $T$ ash Annex and the adoption of conscyuential amendments thereto.

(e) Contributions. The Exccutive Committce may require. as a condition in admission to participation. that the new Contracting Parcy or new Purticipant slaall contribute (in the form of cush. services or materials) an appropriate proportion of the prior budget expenditure of any Task in which it participates.

(f) Replacement of Contracting Parties. With the atgreement of the Execucive Committee. acting by unanimity. and upon the reguest of a government. a concraciing Party designated by that government may be replaced by another party. In ithe everi. of such replacement. the replacement party shall assume the rights and obligations of a Contracting Party as provided in paragraph $(a)$ above and in accordance with the procosurt provided therein.

(g) Withdrawal. Any Contracting Party muy withdraw from this Agremeti: or from any Task either with the agreement of the Executive Committee. acting by unanirrity. 
or by giving twelve months written Notice of Withdrawal to the Executive Director of the Agency, such Notice to be given not less than one year after the date hereof. The withdrawal of a Contracting Party under this paraigraph shall not alfect ihe rights and obligations of the other Contracting Partics: except that. where the wher Contracting Parties hate contributed to common funds for a Task. thicir propurtionalle shares in the Talsk Budger shall be adjusted to take account of such withdrawal.

(h) Changes of Siaress of Contracting Parry. A Contriatinge Party ocher than a government or an international organisation siball forthwith notify the Exocutise Committes

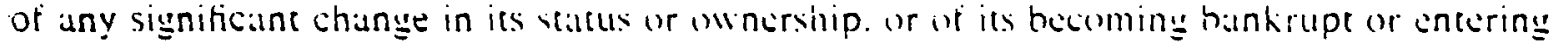
into liquidation. The Executio Conmiste: shall decomine whether any such shange in

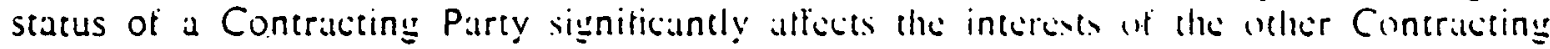
Parties: if the Executivis Committe so determines. then. unlest the Exisutide Comnittes. acting upon the unanimuus decision of the ather Contrating Partics. ofherwise anges:

(1) That Contracting Party siball be deemed to halis withdriwn from the

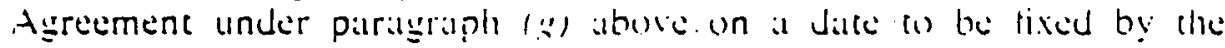
Executive Committee: ind

12) The Executive Commitce shall invite the gorernmenc which desiznated

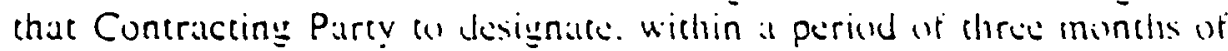
the withdrawal of that Cuntracting Party. a different entity to becume a Contracting Party: if approved by the Executive Committee. actin: by unanimity. such entity shall become a Contracting Party with offect from the date on which it signs or accedes to this Agrcement and gives the Executive Director of the Agency a Votice of Participation in une or more Annexes.

(i) Failure on Fulfil Contractual Obligations. Any Contractings Party which tails to fultil its obligations under this Agreement within sixty days alter its receipt of notice specifying the nature of such failure and invoking this paragraph. may be deemed by the Executive Committee. acting by unanimity, to have withdrawn from this Agrcemen.

\section{Article 11}

\section{FINAL PROVISIONS}

(a). Term of agreement. This Agreement shall remain' in force for an initial period of three years from the date hereof. and shall continue in torce therealter unless and until the Executive Committee, acting by unanimity. decides on its termination.

(b) Legal Relationship of Contracring Parties and Participants. Nothing in this Agreement shall be regarded as constituting a partnership between any of the Contracting Parties or Participants.

(c) Termination. Lpon termination of this Agreement. or any Annex to this Agreement. the Executive Committee. acting by unanimity. shall arrange for the liquidation 
of: the assets of the Task or Tasks. In the event of such liquidution. the Executive Committee shall. so far as practicuble. distribute the assets of the Tash. or the proceeds therefrom. in proportion to the contributions which the Participants have mude from the beginning of the operation of the Task. and for that purpose shall take into account the contributions and anv outstanding obligations of former Contracting Parties. Disputes with a former Contracting Party about the proportion allocited to it under this paragraph shall be settled under Article 9 (d) hereot. for which purpose d tormer Coneractin: Purty shall be regarded as a Contracting Party.

(d) Amendment. This Agreement may be amended at any time by the Executive Committee. acting by unanimity. and any Annex to this Agrcement maty be amended at any time by the Executive Committee. atting by unanimity of the Participants in the Task to which the Annex reters. Such amendments shall come into forcs in a manner determined by the Exccutive Committee. alcting under the voting rule appliciable to tice decision to adopt the amendment.

(ej) : Deposit. The original of this Agreement shall be deposited with the Executive Director of the Agency and a certitied copy thereot shall be furnished to each Contracting Purty. A copy or this Agrecment shall be furnished (1) such Agency Participating Country. to each Vlember country of the Organisation for Economic Conperation and Develupment and to the European Communities.

Done in Paris, this 28th day of June, 1977. 
For the National Swedish Board

for Techical Development

(designated by the Government of Sweden):

For the Office fédéral de la Science

ET DE LA RECHERCHE

DU Départeiment FÉdéral de l'INTÉrieur

for and on behalf of

the Government of Switzerland:

For the UNITED KINGDOM ATOMIC

ENERCY AUTHORITY (designated by

the Government of the United Kingdom

of Great Britain and Northern Ireland):

For the UnITED STATES ENERGy

RESEARCh aNd DEVElOpMENT ADMINISTRation

for and on behalf of the Government of

the United States of America: 
Annex l

EXTENDED SURFACE HEAT TRANSFER

\section{Background and Objectives}

(a) Background. Extended surfaces are used widely in waste heat recovery systems, in recovery of heat from combustion products. in industrial heat exchangers and many domestic applications. In all of these operations, increased efficiency leads automatically to increased energy conservation. but the increase of efficiency can also give rise to smaller plant units, thus enhancing tlexibility in optimising heat recovery. The concept is not new and a large amount of work has been done on the various contiguracions under clean conditions, though there is insufficient data on operational problems such as fouling and humidity effects. However, modern experimental and theoretical methods may now lead to the identification of new. improved surfaces and the need for greater attention to energy conservation may lead to wider applications of extended surfaces.

(b)

Objectives. The objectives of this Task are:

(1) To use modern experimental and analycical techniques to gain a better lundamental understanding of extended surface heat transfer. These techniques could include laser anemometry: intrared thermometry. holographic methods. turbulent flow modetling methods. and numerical solutions. of the conjugated conduction and convection problems:

(2) To produce new data on extended surface systems. allowing better system desienn. This data would include noc only heat transier and pressure Jrop data. but also daca un operational problems such as humidity. ising. particulate fouling and pulsations: and

(3) To attempt to develop new forms of extended surface systems bearing in mind particularty their application and the problems of manufacturing.

2. Means

The work performed under this Task shall consist of three Subtasks as follows:

(a) Sublask 1: Mechanistic studies of the performance of extended surface heat transfer systems. (Responsible Participant: National Swedish Board for Technical Develupment). This part of the work will be aimed at improving understanding of extended surface heat transfer (lirom bodics with limited heat conductivity) to enable better design. The work will include theoretical and experimental studies of the conjugated convection and conduction problem including intrared measurements of timperature distribution. Studies of other mechanistic aspects of extended surface heat transfier may be in. cluded in this Task. as agreed by the Executive Commitree.

(b) Sublask 2: Studies of the performance of practical extended surface sistems. IResponsible Participant: United Kingdom Atomic. Energy Authority). This programme will include the following studies:

(1) Studies of finned cube heac transfer. boch with high and low fin cubing:

(2) Studies of tube-in-plate heat exchangers:

(3) Studies of the performance of air-cooled heat exchangers in various conditions of humidity. and under conditions in which icing of the heat exchangers can vicur: 
(4) Particulate fouling of finned tube systems: and

(5) Effect of pulsations on heat transfer co-efficients and other aspects of pertiormance in extended surface systems.

(c) Subtask 3: Analvtical and experimental investigation of finned tube bundle liquid-gas heat exchangers, and analytical prediction of the heat transfer and pressure loss characteristics of finned tube bundle water-air heat exchangers with counter-cross fow for dry cooling tower or related applications. (Responsible Participant: Office Fédejal de la Science et de la Recherche du Département Féderal de I'Inte. rieur (Sivitzerland), acting through the Institue Fejderal de Recherches en matiere de Rejacteurs). The lollowing work will be sarried out:

(1) Development of relevant theoretical models and computer codes:

(2) Parametric sensitivity studies:

(3) Optimisation of heat exchanger geometry (possible uptimisation critcrion - minimum cotal couling tower investment costs):

(4) Performance tests of commercial and optimised heat exchangers in a special wind iunnel combined with a water loup:

15) Air velocity and temperature distribution measurements: and

16) Experimental optimisation of the heat exchanger arrangement in the couling cowir.

\section{Specific. Responsibilities of the Operating tgent}

Within ninety (90) days of the entry into iorce of this Annex. the Operating Alent will. alter consulting each Participant. prepare and submit to the Executive Cummillec for its approwal a detailed Programme of Work on the form and the scope of the data and reports required from tach Participallt regarding its Subtask for calendar year 1977. By lst December of each year thercatier the Operitiing Agent shall submit a Programme of Work for the following vear. The Programme ut Work including the links between the mectanistic studies (Subtask 1) and the more applied studics in ithis Subtast.. ivill be adopted by the Executive Committee. acting by unanimicy.

\section{Time Schedule}

The duration of this Task shall be three years. It may be extended by decisiun of the Exclutive Commitce. acting by unanimity.

\section{Funding}

\section{Research Cosis}

(1) Each Participant shall be responsible for providing the financial resources nectssalry to carry out ies research responsibilities under this Annex. The Participants minimum levels of expenditure under the Task shall be as follows:

Nacional Swedish Board for Technical Develupnine SwK +50.000

Office Federal de la Science et de la Recherche du

Departement Fèderal de linterieur (Switzerland)

SFr 250.000

United Kingdom Aromic Energy Authority.

at April 1977 exchange rates and money values. 
(2) The Executive Committee. acting by unanimity. shall adjust the nigures referred $t o$ in this paragraph at half-yearly intervals to take account of changing price levels in the country of each Participant to ensure that the necessary real resuurces will continute to be available to conduct the work called for. If significant changes in such price levels occur. the Executive Committee. acting by unanimicy. shall consider whether to adjust the Programme of Work to the available funds.

(b) Other Costs. Each Participant shall also bear all other costs it incurs in carrying vut this Annex. including the costs of formulating or transmitting reports and of reimbursing its emplovetes for travel and ocher per diem expenses incurred in connection with work earried uut un the respecilic Tisks.

(c) Financial Statement. Not later than three months after the close of each finuncial yeur esach Participant shall submit to the Execuiive Committee a detailed financial statement concerning expenditures for the Task during the financial year. Each Participane shall make available such actditional tinancial intiormation on expenditure for the Task as the Executive Committee may reasonably reyuest in order to ensure that the Task is being carried out in accordance with this Agresment.

\section{h.. Operating Agent}

United Kingdom Atomic Energy Authority.

\section{i. Information and Intellectual Property}

(a) Executive Commitree's Powers. The publication. distribution. handling. procection and uwnership of information and intellectual property arising from activities conducted under this thenex $I$ to the IEA Implementing Agreement for a Programme of Research and Development un Energy Cunser. vation in Heat Transter and Heat Exchangers (hereinatiter called Annex /) shall be detcrmined by the Executive Committee. acting by unanimity. in conformity with this Agreement.

(b)

Right to Publish. Subject only to patents and copyright restrictions. the Annex I Participants shall have the right 10 publish all iniormation provided to ur arising irom Annex $l$ except proprietary infor. mation. but they shall not publish it with a view to profit except as the Executive Committee. acting by unanimity. mav agree or provide by rule. All that information shall be available without charge to the Participants.

(c)

Proprietary Injormation. The Annex / Participants shall take all necessary medsures in accordance with this paragraph. the laws of their respective countries and international luw to protect proprietary intormation. For the purposes of this Annex proprietary iniormation shall mean iniormation of a corifidential natupe such as trade secrets and know-how (for example. cumputer programmes. design procedures and techniques. chemical composition. of materials. or manulacturing methods. processes. or treatments) which is appropriately marked. provided such information:

(1) Is not generally known or publicly available from other sources:

(2) Has not previously been made available by the uwner to uthers withuut ubligation concerning its contidentiality: and

(3) Is not already in the possession of the recipient Annex / Participant without ubligation concerning its confidentiality.

Proprietary intormation shall not be accepted for or utilised in the Task without express approvial of the Participants. It shall be the responsibility of each Participant suppiying proprietary inturmation to identity the information as such and to ensure ihat it is appropriately marked. 
(d) Production of Relevant Information by. Governments. The Responsible Participant should encourage the governments of all Agency Participating Countries to make available or to idencify to the Responsible Participant all published or otherwise freely available information known to them that is relevant to the Subtask. The Participants should notify the Responsible Participant of all pre existing information, and information developed independently of the Subtask. known to them which is relevant to the Subtask and which can be made available to the Subtask without contractual or legal limitations.

(e) Reports on Programme Work. Each Responsible Participant shall provide repurts of all work performed under its Subtask and the results thereof (arising information). ocher. than proprietary information. to the Executive Committee. Reports containing arising intormation and pre-existing intiormation necessary for and used in each Subtask. including proprietary inturmarion. shall be provided to each Annex I Participant by the Annex / Participant performing the Subtask. It shall be the respunsibility of each Participant to identify information which qualifics as proprietary intormation under this Annex and ensure that it is appropriately marked.

(1) License of Proprietary Information. Each Participant agress to license inll pre-txisting proprictary intormation. necessary for and used in its Subcask. Which it uwns or controls and all arising proprietary information to the Annex / Participants. their governments. And the nationals of their respective countries designated by them:

(1) Royalty-free for use in their country only: and

12) On reasonable terms and conditions for use in all vcher countrics.

Each Participant agurees to license all such arising proprietary intormation to all Agency Participating Coun. tries on reasonable terms and conditions for use in their own country in order to mee: their energy needs.

(g) License of Patents Veeded for Task. Patents solety owned ur cuncrolled by thnex I Participants which are needed for use in a Subcask shall be licensed to the Responsibie Participanc for use in the Subtask only at no cost to such Participant. If such patents are partially owned or cuntrulled by a Participant. then efforts shall be made by the Participant to reduce or etiminate as possible the benerit that might accrue to it.

(h) Arising Inventions. Inventions made or conceived in the course of or under any Subtask (arising inventions) shall be owned in all countries by the inventing Participant. Intiormatiun regarding inventions on which patent protection is to be vbtained by the Participanc shall noc be published ur pubticly disclosed by the other Participants until a pacent application has been filed. provided. huwever. that this restriction on publication or disclosure shall not extend beyond six months from the date of receipt of such information. It shall be the responsibility of the inventing Participant to appropriatcly murk reports which disclose inventions that have not been appropriately protected by the tiling of a patent applicacion.

(i) License of Inventions. Each Participant agrees to license all pre-cxisting inventions covered by patents owned or conirolled by it which are necessary for practising the results ut its Subcask and which have been utitised in the Subtask. and ail arising inventions to the Antex / Participants. their govern. ments. and the nationals of their respective countries designated by them:

\section{(1) Royalty-free for use in their country only: and}

(2) On reasonable terms and conditions for use in all other councries.

Each Participant agrees to license all such arising inventions to all Agency Participating Cuuntrics un reasonable terms and conditions for use in their own country in order to meet iheir energy needs.

(j) Copyright. The Operating Agent or each Participant lor its uwn Subcask resuits maly laks appropriate measures necessary to protect copyrightable material generated under any Subtask. Cupyrights obtained shall be the property of that Participant or the Operating Agent. provided. huwever, that t/lnnex $/$ Participants may reproduce and distribute such material. but shall not publish ir with a vicw to prorii. 
Inventors and Authors. Each Annex / Participant will. withuut prejudice to any rights of inventors or authors under its national laws. take all necessary steps to provide the co-operation liom its authors and inventors required to carry out the provisions of this Article. Each Anner / Purticipant will assume the responsibility to pay awards or compensation required to be paid to its employces alccurding to the laws of its country.

(1) Determination of "National". The Executive Commitce may establish guidelines to determine what constitutes a "national" of a Participant. Disputes that cannot be settled by the Executive Cummittes shall be settled under Article $y(d)$ of the Agreement.

\section{Results}

The results of these co-operative activities will be:

(a) Brief progress reports on the project will be presented twice yearly and the project discussed in detail annually at a meeting of the Executive Cummicter: and

(b) A final report on the three year projest in ail Subcask areas will be prepared and sub. mitted in dratt to the Executive Cummittee by the Opurating Aggent with the assistance of the ocher Participants.

Each Participant will be entitled to receive a copy of each of the reports un the results of the co-vperative activities in this Task.

\section{Participants in the Task}

The Cuntracting Parties which are Participants in this Task are the following:

The National Swedish Board for Technical Develupment

The Otfice Federal de la Science et de la Recherche du Dipartement Fidiral de l"Interieur (Switzeriand)

The United Kingdom Atomic Energy Auchority 
Annex $/ 1$

THE OPTIMAL DESIGN OF HEAT EXCHANGER NETWORKS

\section{Background and Objectives}

(a) Background. In many chemical and metallurgical processes it is esscntial to re:surer and recycle energy. The most important part of this energy recovery is by way of heat transtiur betwen the ourgoing hot and incoming cold streams. Cumplete heat recovery is only possible by having inrinite surtace area and. even in that case. irreversible energy losses will still occur due to pressure drups in the system. Obviously. the best design must be the result of a careful uptimisation taking account of the costs involved. including the cost benefit of energy saving. Though cost factors will rule out many energy cunservation possibilities. opportunities for energy conservation shouid not be missed in default of adequille cuols ior benefit analysis. The aim of this programme will be to examine the available touls and assess their vability.

Objectives. The objectives of this Task are:

(1) To develop a better understanding of the techniques already emploved in inclustry. and also those which might be available from universicy and vither suurcis:

(2) Through practical studies of the techniques. to promote their more widespread usi in industry : and

(3) To further develop the stace of the art un uptimisation of thermal dising througn appropriate research and development eflorts.

2. Vleans

The work performed under this Task shall çonsist of the lullowing four Subtasks.

(a) Subcask l: Optimisation .Hethods (Responsible Participant: Lnited Kingulum Atomic Energy tuchority). To prepare a review and assessment of the various optimisation methods available and of puolished case studies. To test available computer programmes and assess thuir relevanct co industrial application.

(b) Subcask 2: Case Sudies in Swedish Industry. IResponsible Participant: National Swedish

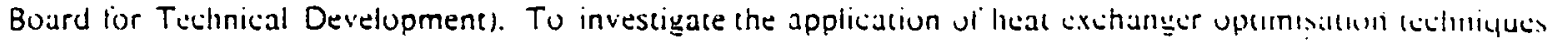
in one or more wase studies with the so-uperation of Swedish industry.

(c) Subtask 3: Case Studies in British Industry. IRosponsible Parmcipint: Linitcd Kingugum Atomic Energy Auchority). To investigate the application of heat exchanger nptimisation kchniyut: in one or more case studies with the so-operation of Uniled Kingulum industry.

(d) Subcask t: Preparacion of Report and Recommendacions, iRespunsible Parricipunt: United Kingdom Acomic Energy tuthority). Lines for lucure work wuld. it appropriate. be specilied in this report.

\section{Specific Responsibilities of the Operating tgent}

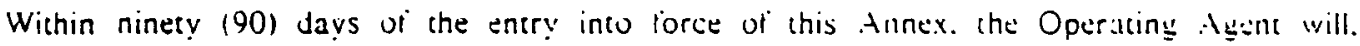
atter consulting each Participant. prepare and submit to the Executive Cummitce fior its approvil at detailed Programme of Work on the form and the scope oi the data and reports requircd irom each Participant regarding its Subcask for calendar year 1977. By lis December of cach vear therealter the Operating tegent shall submic a Programme of Work for the tollowing year. The Programme of Work will be adopted by the Executive Committee. acting by unanimity. 
The duration of this Task shall be two years. It may be extended by decision of the Exciutive Commictes. acting by unanimicy.

\section{Funding}

(a)

\section{Research Costs}

(1) Each Participant shall be responsible for providing the tinancial resuarces necessary to carry out its research responsibilities under this Annex. The Participants minimum levels of expenditure under the Task shall be as lollows:

First year

Linited Kingdom Atomic Energy Authority

Second l'ear

Vational Swedish Board for Texhnical Development

$S w K+5.000$

United Kingdom ttomic Energ̣y Authority

12) The Executive Committee. acting by unanimity. shall adjust the figures refierred to in this paragraph at half-yearly intervals to take account of changing price levels in the cuuntry of each Participant to ensure that the necessary real resources will cuncinue to be available to conduct the work called for. If signiticant changes in such price levists uccur. the Executive Committee. acting by unanimity. shall cunsider whether to adjust the Programme of. Work to the availabte tunds.

(b) Other Costs. Each Participant shall also bear all other costs it incurs in tarrying vut this Annex. including the costs of lormulating or transmicting reports and of reimbursing its impluyees for travei and other per diem expenses incurred in connection with iwork sarricd out on the respective Tasks.

(c) Financial Statement. Not later than three months alter the stose of tach tinancial yuar sach Participant shall submit to the Executive Committee a detailed tinancial statcment concerning cxpenditures for the Task during the hnancial year. Each Participant shall makc available such additional rinancial intormation or expenditure for the Task as the Executive Commille may reasonably reyutst in order to insure that the Task is being carried out in accordance with this Agreement.

\section{Operating tgent}

United Kingdom Atomic Energy Authority.

\section{Information and Intellectual Property}

(a) Executive Committee's Powers. The publication. distribution. handling. protectiun and awnership of iniormation and intellectual property arising from activities conducted under this fthmex /I 10 the IE.A Implementing Agresment for a Programme of Research and Development un Enirgy Cunser. vation in Heat Transfer and Heat Exchangers (hereinafter called dnnex $/ /$ ) shall be determined by (he Executive Cummittee. acting by unanimity. in conformity with this Agreement.

(b)

Right to Publish. Subject only to patents and copyright restrictions. the thutex /l Participants shall have the right to publish all information provided to or arising from thllex // except proprietary intiormation. bus they shall not publish it with a view to protit except as the Executive Cummiltce. acting by unanimity. may agree or provide oy rule. All that intormacion shall be available without charge to. the Participants. 
(c) Proprietary Informacion. The Annex /l Participants shall lake all necessary measures in accordance with this paragraph, the laws of their respective countries and internationil law to protect proprietary intormation. For the purposes of this Annex proprietary intormation shail mean infurmation of a contidential nature such as trade secrets and know how (for example. compuler programmes. design procedures and techniques. chemical composition of materials. or manulacturing methods. processes. ur (reacments) which is appropriatély marked. provided such information:

(1) Is not generally known or publicly available from uther sources:

(2) Has not previously been made available by the owner to others ivithuut obliyation concerning its confidentialicy: and

13) Is not already in the possession of the recipient Annex // Participam withuut obligation concerning its contidentiality.

Proprietary information shall not be accepted for or utilised in the Task without express approval ul the Participants. It shall be the responsibilicy of each Participant supplying proprictary intiormatiun co idenciì the intormation as such and to ensure that it is appropriately marked.

(d) Production of Relevant Information by Governments. The Respunsible Participatlt shuuld encourage the governments of all Agency Participating Councries to matke atrailable ur to identily to the Responsible Participant all published or otherwise freely available iniormation known io them that is relevant to the Subcask. The Participants should notify the Responsible Participant ul all pre cxiscints iniormation. and intiormation developed independently of the Subtask. known to them which is ictevint to the Subtask and which can be made available to the Subtask withuut contractual ur kegal limitations.

(e) Reports on Programme Work. Each Respunsible Participant ihall provide icpurts uf all work pertormed under its Subcask and the results thereof (arising iniurmation). uther than pruprietary intormation. 10 the Executive Committee. Reports containing arising inturmation attd pre cxistine intur. mation necessary for and used in each Subcask, including proprietary inturmation. shall be provided to each Annex // Participant by the Annex // Participant pertorming the Subcask. It shall be the respunsibility. of each Participant to identify information which qualities as proprietary inturmatiun uncier chis Annex and ensure that it is appropriately marked.

(1) License of Proprielary Information. Each Participant agrees to license all pre exiscing proprietary information. necessary for and used in its Subtask. which it uwns ur controls and all arising proprietary iniormation to the Annex II Participants. their governments. and the natiunalis ul their respec. ive countries designated by them:

(1) Royalty-free for use in their country only: and

(2) On reasonable cerms and conditions for use in all ocher countries.

Each Participant agrees to license all such arising proprietary intormation to all Agency Participacing Countries on reasonable terms and conditions for use in their uwn country in order to meet their encry! needs.

(g) License of Patents Needed for Task. Patents solely owned ur controlled by tinnex II Participants which are needed for use in a Subtask shall be licensed to the Responsible Participunc lor use in the Subtask onily at no cost to such Participant. If such patents are partially uwned ur controlled by a Participant. then effors shall be made by the Participant to reduce or eliminate as pussible the oenetic that might accrue to it.

(h) Arising Inventions. Inventions made or conceivid in the course vi ur under iny Subcisti (arising inventions) shall be owned in all countries by the inventing Participant. Inturmution regarding inventions on which patent protection is to be obtained by the Participant shall not be published ur publicly: 
disclosed by the other Participants until a patent application has been filed. provided. however. that this restriction on publication or disclosure shall not extend beyond six months from the date of receipt of such intormation. It shall be the responsibility of the inventing Participant to appropriately mark reports which disclose inventions that have not been appropriately protected by the filing of a patent application.

(i) License of Inventions. Each Participant agrees to license all pre-existing inventions covered by patents owned or controlled by it which are necessary for practising the results of its Subiask and which have been utilised in the Subtask. and all arising inventions to the Annex /I Participants. their governments. and the nationals of their respective countries designated by them:

(1) Royalty-free for use in their country only: and

(2) On reasonable terms and conditions for use in all other councries.

Each Participant agrees to license all such arising inventions to all Agency Participating Cuuntries on reasonable terms and conditions for use in their own country in order to meet their energy needs.

(j) Copyright. The Operating Agent or each Participant for its own Subcask results may take appropriate measures necessary to protect copyrightable material generated under any Subtask. Cupyrights ubcained shall be the property of that Participant or the Operating Agent. provided. however. that Annex /I Participants may reproduce and distribute such material. but shall nut publish it with a view to protit.

(k) Invencors and Authors. Each Annex /I Participant will. withouc prejudice 10 any rights of inventors or authors under its national laws. take all necessary steps to provide the co-uperatiun irum its authors and inventors required to carry out the provisions of this Article. Each . tnne.r // Participant will assume the responsibility to pay awards or compensation required to be paid to its empluyees accordins to the laws of its country.

(l) Determination of "Vational". The Executive Committee may establish guidetintes to determine what constituses a "national" of a Participant. Disputes that cannut be settled by the Exccutive Committee shall be settled under Article $\varphi(d)$ of the Ayreement.

\section{Resulis}

The resuits of these co-operative activities will be:

(a) A first draft of the review document will be produced by the United Kingdom Acomic Energy Authority at the end of the first year. This will then form the basis of consideration of the case studies to be carried ouc by Sweden and by the Uniced Kinguom in the second year of the study:

(b) A tinal report on the two-vear project in all Subcask areas will be prepared and submitted in draft to the Executive Committee by the Operating. Agent with the assistance of the uther Parricipants.

Each Participant will be entitled to receive a copy of each of the reports on the results ul the cu-uperative activities in this Task.

9. Participants in the Task

The Contracting Parties which are Participants in this Task are the following:

The National Swedish Board for Technical Development

The United Kingdom Atomic Energy Authority 
HEAT EXCHANGER TUBE VIBRATION

\section{Background and Objectives}

(a) Background. In order to minimise heat exchanger costs, and promote better energy vunservation. it is desirable to have higher velocities in many heat exchanger systems. However. these higher velocities lead to consequential tube vibration and this often porces the designer to usi a nun-uptimal design. Thus. tube vibration is an important area for study if progress is to be madt in energy ionservation.

(b)

Objectives. The objectives of this Task are:

(1) To develop an understanding of the mechanisms of cube vibrations within heat exchanyers leading to calculation meshods for idealised cases:

(2) To consider in detail the application of fundamental methuds for vibrutiun prediction to the actual cases of heat exchanger contigurations:

(3) To contirm. in fietd and other large-scale tests. the applic:abilit: of predictive methods: and

(4) To reduce to oractice the predictive methods devcloped.

\section{Means}

(a) Areas of Work

below.

The work performed under this Task shall consist of five Suhcuskis in three arias dis set lorth

Area A: Excitation :Mechanisms. The work to be pertiormed includes the identitication and characterisation of lluid excitation mechanisms in lube bundles represenciative vi he:ll exchanger tube banks. These mechanisms may include lluid elastic whirling. wilke lluws (vortex-shedding). turbulent butfeting. and acoustic excitation.

Area 8: D!namic Characteristics of :hulti-span tssemblies. The aims ut this part of the Task are:

(1) To measure the damping characteristics of a lube ivith multiple supports simuiating the tube-baifle arrangements of shell and tube heat exchangers:

(2) To correlate the damping in terms of the parameters of the system in a way which will enable designers to use the data easily. Parameters of main interest will be the hole clearance factor. the baffle thickness/tube diameter ratio. the batfle spacing and freyuency:

(3) To attempt to represent the dynamic behaviour by müns of a conceptual modet: and

(4) To study the effect of deviation irom classical support cunditions un model irequencies. and. if possible. correlate the effects in terms of the controlling parameters.

Area C: Information Exchange. The aim of this part of the Task is to encourage interchange: of information between the Participating Countries and to provide tacilities for such interchunge. 
Subrask A.l: Experimental Studies of Fluid Elastic Whirling of Cantilevered Elements. (Responsible Participant: Uniced Kingdom Acomic Energy Authority) A scries of experiments will be planned and carried out to determine the effect of getomestic parancters le.g. tube spacing) on the threshold velocity associated ivith nuid elastic whirling linstability in tubc banks). The tests will be nerformed in boch air and water utilising the salme cest scetion. In

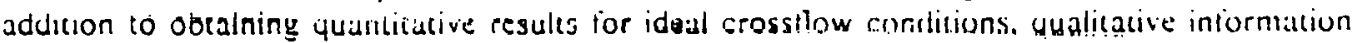
on the etrect of baffle plates and turbulence grids will be obcained.

Subtask 4.2: Integrated TheoreticallExperimental Studies of Fluid/Strucure Coupling in Tube Banks. IResponsible Participant: Lnited States Energy Rosisarch and Develupment Administration). Theoretical studies will be performed to account for lluidistructure coupling in tube bundles as a function of tube geometry. tube spacing. mass density ratio and flow velucity. A complementary experimental programme will be planned and warried uut io evaluate the analytical methods. with llow tests proseressing from single cubceruws (u) (ube bundles and heat exchangers.

Subrask .4.3: Turbulent Bujfering. IResponsible Participant: Vational Swedish Buard for Technicall Develupment). Scudies will be periormed (o evaluate ('e flliect ut curbutence (scale and intensity) on heat transier and on the resulting lluid lurces alcing un al cube in cruss. llow and un vortex shedding. Such results are expected to contributic to tharacterisaltion of related heat transier and fluid lorcing functions.

Sublask A.t: Vorter Shedding. IResponsible Participant: Oitice Federal de la Science et de la Recherche du Departement Federal de l'Inciricur (Swiczerland). acung through Sulzer Brothers. Lid.). The vortex lurmation and instability of wakes and jets as excitation sources in cube banks will be investigated. The fields of the cube spacing racios subjected io von Karman vortex shedding. wake swing and jet inscabilicy will be determined. and the Strouhal number and dynamic lorce will be measured. With respect to mechanical tube vibrations, it will be determined which held of cube spacing rasios is exposed to the excitation of the fluid-elastic coupling and which tield is only subjected to the vortex excitation.

Subtask B.l: :Heasurements of Damping and Frequenci. IRespunsible Participant: United Kingdom Atomic Energy Authority). A test rị̧ will be ucilised. cumprising a inilisibe base plate in which grouves are machined to acceps places (simulating̣ ballles) which un be readily moved to alcer the spacing. The cube will be solidly ciamped at buth ends to represent rixing in a cube sheet. Tube diameter and sube-10-ballte hole slearance will be varied uter a rane consistent with sheil and tube heat exchanger practice. U.bends will alsu he included in the tests.

Subtask C.l: International Conjerence. IResponsible Participant: Unilcd States Energy Research and Development Administration). The Respunsible Participant ior this Subtask has organised an international conterence on heal texchanger cube vibrations. A. written record of the major tectinical contributions and cunclusiuns irom this conterence has been prepared and will be distributed by the Responsible Participant. This document incor. porates a proprietary report on heat exchanger tube vibratiun. purchased from Heat Trans. ler Research. Inc., and ten copies of the complecte ducument will be distributed to each Participant.

\section{$\therefore \quad$ Specific Responsibilities of the Operating igent}

Within ninety $(90)$ days of the entry into force of this Annex. the Operatilly Aecnt will. atter consulting each Participant. prepare and submic to the Exccucive Committet for its approval a detailed 
Proyramme of Work on the form and the scope of the data and reports required from each Participant regarding its Subtcisk for calendar vear 1977. By lst December of each year thereatier the Operacing Agent shall submit a Programme of Work for the following year. The Programme of Work including the links between the mechanistic studies and the more applied studies will be adupted by the Exccutive Committee. acting by unanimity.

\section{Time Schedule}

The duration of this Task shall be three years. It may be extended by decisiun vi the Exccutive Committee. acting by unanimity.

\section{Funding}

\section{(a) Research Costs}

(1) Each Participant shall be responsible for providing the financial resources necissary: to carry out its research responsibilities under this tnnex. The Participantis minimum levets oi expenditure under the Task shall be as folluws:

National Swedish Board for Technical Develupment

SwK $2 \geq 5.000$

Office Fèderal de la Science et de la Rechercine du

Département Federal de I"Intirieur (Sivitzeriand)

SFr 120.000

United Kingdom Acomic Entrgy Authority

Uniced States Energy Research and Developmunt Administration

(2) The Executive Committee. acting by unanimity. shall adjust the figures retiorred is in this paragraph at half-yearly intervals to take account of changing price livels in the country of each Participant to ensure that the necessary rcal resuurtis ivill concinuc to be available to conduct the work called for. If signiticant changess in such price livels uccur. the Execusive Committee. acting by unanimity. shali consider whother to adjust the Programme of Work to the available lunds.

(b) Other Costs. Each Participant shall also bear all uther costs it incurs in tarrying uut this Annex. including the costs of formulating or uransmitring reports and of reimbursing its empluvees lur ravel and other per diem expenses incurred in connection with work sarricd uut un the respective Tiustis.

(c) Financial Statement. Not later than three months alter the stuc of with rinuncial piat each Participant shall subrnit to the Executive Cummittee id detailed tinancial statement concerning expend. itures for the Task dusing the tinancial year. Each Participant shail make available such additional financial information un expenditure for the Task as the Executive Committee may reasunably reyucst in urder to ensure that the Task is being carried out in accordance with this Agreement.

\section{Operating Agent}

United Kingdom Atomic Energy Authority.

\section{Information and Intellectual Property}

(a) Executive Committee's Powers. The publication. distribution. handling. procection ithl ownership of intormation and intellectual property arising from activities conducted unde his thlmex $/ 1 /$ to the IEA Implementing Agreement for a Programme of Research and Develupment un Energy Cunser. vation in Heat Transier and Heat Exchangers (hereinafter called thnex (II) shill be determined by the Executive Committee. acting by unanimity, in contormicy with this Ayreement. 

icipants shall have the right to publish all information provided to or arising from Annex III excepc proprietary information. but they shall not publish it with a view to profit except as the Executive Cummittee. acting by unanimity. may agree or provide by rule. All that informatiun shail be available withuut charge: to the Participants.

(c)

Propriesary Information. The Annex III Participants shall lake all necessary measures in accordance with this parayraph. the laws of their respective countries and international law to procect proprietary infurmation. For the purposes of this Annex proprietary intormation shall mean inturmation of a contidential nature such as trade secrets and krow how for example. computcr programmes. design procedures and techniques. chemical composition of materials. or manulacturing methods. proctesses. ur (reatments) which is appropriately marked. provided such intormation:

(1) Is noc generally known or publicly available from orher sources:

12) Has noc previously been made available by the uwner to uthers without ubligation concerning its confidencialicy: and

13) Is not already in the possession of the recipient Annex /I/ Participant withouc ubligation cuncerning its confidentialicy.

Proprietary intormation shall not be accepted for or utilised in the Task without cxpress appruval of the Participants. It shall be the responsibility of each Participant supplying proprictary intormation co identily the intormation as such and to ensure that is is appropriately marked.

(d) Production of Relevant Injormation by Governments. The Respunsible Participant shuuld encourage the governments of all Agency Participating Cuuntries to make avaliable ur to identity to the Responsible Participane all published or otherwise freely availablic intormation known to them that is relevant to the Subtask. The Participants should notify the Responsible Participant of all pre texisting intormation. and information developed independently of the Subtask. knuwn to them which is retevante to the Subcask and which can be made available to the Subtask without contractual or legal limitaliuns.

(e) Reports on Programme Work. Each Responsible Participant shall providu repurts ul all work pertormed under its Subcask and the results thereot larising informationi. wher than proprictary intormation. to the Executive Committee. Reports containing arising intormation and pre existing intiormation necessary for and used in each Subtask. including proprietary inturmation. shall be provided tu wach Amex III Participane by the Annex /II Participant pertorming the Subask. It shall be the respunsibility of each Participant to identify information which qualifies as proprietary intormation under this Annex and ensure that it is appropriately marked.

(1). License of Proprietary Information. Each Participant agrees to license all pre cxiscing proprietary iniormation. necessary for and used in its Subtask. which it owns ur coultrols and all arisine proprietary intormation to the fnnex $/ I I$ Participants. their governments. and the naciunals of their respective countries designated by them:

(1) Royalty-free for use in their country only: and

(2j) On reasonable terms and conditions for use in all veher councries.

Each Participani agrees to license all such arising proprietary infurmation to all Agnensy Participaling Countries on reasonable terms and conditions for use in their uwn country in urder to metet thuir cnergy needs.

(g) License of Patents :Veeded for Task. Patents solely owned or controlled by thmex III Participants which are needed for use in a Subtask shall be licensed to the Respunsible Participant lor use in the Subtask only at no cost 10 such Participant. If such patents are partially uwned ur cuntrulled by a Participant. then efforts shall be made by the Participant to reduce or eliminate as possible the benefit that might accrue to it. 

iarising inventions) shall be owned in all countries by the inverting Participant. Iniormation regarding inventions on which patent protection is to be obtained by the Participant shall nut be publistred ur publicly disclosed by the other Participants until a patent application has been filed. provided. howeter. that this restriction on publication or disclosure shall not extend beyond six months trum the date of recieipe of such intormation. It shall be the responsibility of the inventing Participant to appropriately mark repurts which disclose inventions that have not been appropriately protecied by the itling of a patent application.

(i) License of Inventions. Each Participant agrees to license all pre existing inventions corcred by patents owned or controlled by it which are necessary for practising the risulis of its Subtask and which have been utilised in the Subcask, and all arising inventions to the dintex /I/ Participants. their governments. and the natiunals of their respective councries designatid by tilcm:

\section{(1) Royaity.free for use in their country only: and \\ 12) On reasonable cerms and conditions for use in all ucher suuntrics.}

Each Participant agrees to license all such arising inventions to all fugency Partucipalin: Cuuntrics un rejsunable terms and condicions for use in their own country in order io meet the:r encroy nevds.

(j) Coptright. The Operating Agent or each Participant lor its uwn Subcisk results may lake appropriate meadsures necessary to protect copyrightable matcrial gencralcu under any Subcusk. Cupyrights ubtained shall be the properey of that Participant or the Operaline testnt. pruvided. huwever. that finnex /I/ Participants may reproduce and distribute such material. but shall nut publisis it with a vicu to profit.

(k) Inventors and Authors. Each Annex lll Participant will, without prejudice to an! rights of inventors or authors under its national laws. take all necissary sleps to provide the co-uperatiun trom its authors and inventors required to carry out the provisions of this Article: Each thmex /l/ Participant ivill assume the responsibility to pay awards or compensation required to be paid to its smpluyeres itiourding to the laws of its country.

(1) Determination of "Vational". The Executive Committer may establish guidelines w determine what constitutes a "national " of a Participant. Disputes that cannot be settled by the Executive Committee shall be settled under Article $y(d)$ ot the Agreement.

\section{Resulis}

The results of these co-operative activities will be:

(a) Briet progress repurts on the project will be prescnted ivict vairly and the project discussed in decail annually at a meering of the Execulave Cummille::

(b) An international conference on heat exchanger cube vibration and a written report un the major technical sontributions and conclusions: and

(c) A final report on the three-vear project in all Subtask areas will be prepared and jub. mitted in dratt to the Executive Committes by the Operating Agent with the assistance oi the other Participants.

Each Participant will be entitled to receive a copy of each of the reports un ihe results of the conperame activities in this Task. 
9. Participants in the Task

The Contracting Parties which are Participants in this Task are the folluwing:

The National Swedish Board for Technical Development

The Office Federal de la Science et de la Recherche du Departement Féderal de I"Interieur (Swizzerland)

The United Kingdom Atomic Energy Authority

The United Staces Energy Research and Development Administration 